Portland State University

PDXScholar

8-2001

\title{
Low-Income Homeownership in Portland's Albina Community: A Comparative Analysis of Housing Quality in Market-Rate and Subsidized Houses
}

Carolyn Emily Collopy

Portland State University

Follow this and additional works at: https://pdxscholar.library.pdx.edu/open_access_etds

Part of the Human Geography Commons, Social Welfare Commons, and the Urban Studies Commons Let us know how access to this document benefits you.

\section{Recommended Citation}

Collopy, Carolyn Emily, "Low-Income Homeownership in Portland's Albina Community: A Comparative Analysis of Housing Quality in Market-Rate and Subsidized Houses" (2001). Dissertations and Theses. Paper 2809.

https://doi.org/10.15760/etd.2808

This Thesis is brought to you for free and open access. It has been accepted for inclusion in Dissertations and Theses by an authorized administrator of PDXScholar. Please contact us if we can make this document more accessible: pdxscholar@pdx.edu. 


\section{THESIS APPROVAL}

The abstract and thesis of Carolyn Emily Collopy for the Master of Science in

Geography were presented August 8, 2001, and accepted by the thesis committee and the department.

COMMITTEE APPROVALS:

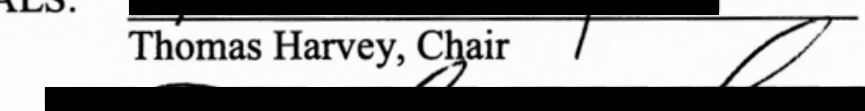

Daniol M. Johnson

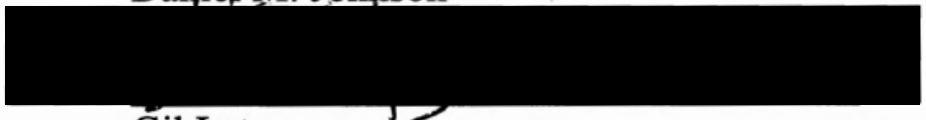

Gil Latz

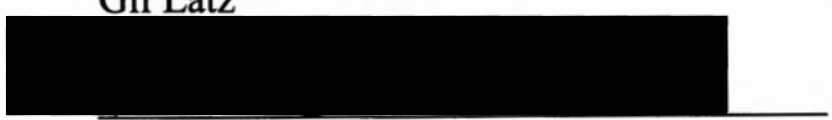

Gerard Mildner

Representative of the Office of Graduate Studies

DEPARTMENT APPROVAL:

Teresa Bulman, Chair

Department of Geography 


\begin{abstract}
An abstract of the thesis of Carolyn Emily Collopy for the Master of Science in Geography presented August 8, 2001.

Title: Low-Income Homeownership in Portland's Albina Community: A Comparative Analysis of Housing Quality in Market-Rate and Subsidized Houses.
\end{abstract}

Housing embodies much more than just a physical commodity. In addition to being an investment, it is our shelter, right to privacy, connection to community, and access to recreation and necessities. Homeownership has long been hailed by social and housing advocates as an economic stabilizer for low to moderate-income neighborhoods. For low and moderate-income residents (households earning 50$100 \%$ of the median income), homeownership is possible in two forms: affordable market-rate housing created by the filtering down of houses until affordable to low and moderate-income households, or through subsidized homeownership programs which develop new housing and offer financial assistance for low and moderateincome households.

The purpose of this study was to determine which of these two options, market-rate or subsidized, offer higher quality affordable housing to low and 
moderate-level income households. Through field observation and GIS analysis, the study compared the structural, block, neighborhood amenity, crime, and proximity to $\mathrm{CBD}$ characteristics of affordable market-rate and subsidized houses in Portland's Albina Community. The study samples were approximately 100 houses per sample; market-rate houses consisted of houses that sold during 2000 for $\$ 125,000$ or less, and subsidized houses were selected from housing created by three local non-profit development agencies.

General characteristics of the two samples revealed subsidized houses were larger and more affordable per square foot than the market-rate houses in Albina. Descriptive statistics showed little overall difference between the two samples in structural, block, neighborhood amenity, and crime characteristics. However, distribution of the two samples varied widely, and consequently subsidized houses were 1 to 2 miles closer to the CBD than market-rate houses. While quality between the two types of affordable housing is currently comparable, the study suggests these trends may soon be threatened by future maintenance needs and neighborhood upgrading. 
LOW-INCOME HOMEOWNERSHIP IN PORTLAND'S ALBINA COMMUNITY:

A COMPARATIVE ANALYSIS OF HOUSING QUALITY IN

MARKET-RATE AND SUBSIDIZED HOUSES

by

CAROLYN EMILY COLLOPY

A thesis submitted in partial fulfillment of the

requirements for the degree of

MASTER OF SCIENCE

in

GEOGRAPHY

Portland State University

2001 


\section{Acknowledgements}

I'd like to thank the following for their time, energy, and support:

Tom Harvey, Jenni Severson, Karen Howell Rice, Lori Cooke, Trell Anderson,

Leanne Torgerson, Mardi Thompson, HOST Development Inc., Chris Moore,

Li Alligood, Gerard Mildner, Gil Latz, Dan Johnson, and of course, Jon Steinhorst. 


\section{Table of Contents}

List of Tables iv

List of Figures

Chapter I - Introduction 1

Home Ownership for Low to Moderate-Income Households 4

The Filtering Process $\quad 4$

Subsidized Housing $\quad 9$

$\begin{array}{ll}\text { The Study Site } & 13\end{array}$

Albina Community History $\quad 13$

$\begin{array}{ll}\text { Albina General Characteristics } & 15\end{array}$

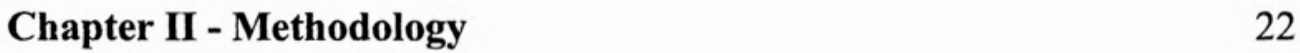

Chapter III - Results $\quad 32$

$\begin{array}{ll}\text { Area Characteristics } & 32\end{array}$

$\begin{array}{ll}\text { General Sample Characteristics } & 38\end{array}$

$\begin{array}{ll}\text { Distribution } & 38\end{array}$

Sample Sale Price, Cost per Square Foot,

Dwelling Size, and Age Characteristics $\quad 47$

Quality Indicators $\quad 49$

Exterior Physical Quality $\quad 49$

Block Rating $\quad 54$ 
Neighborhood Amenities

Area Crime Rates

59

Proximity to Portland's CBD

60

Chapter IV - Discussion and Conclusion

62

References

71

Appendix A - Examples of Structural Quality Survey Model 78

Appendix B - Survey Data

85 


\section{List of Tables}

2.1. Household Income Guidelines, City of Portland

Bureau of Housing and Community Development,

2000.

2.2. Sale Adjustment Rates Based on Repeat Sales

Reported, Real Estate Report, 2000.

3.1. Total Square Feet, Sale Price, Cost per Square Foot, and Year Built for Sampled Market-Rate and

Subsidized Houses.

3.2. Exterior Physical Quality Ratings for Sampled

Market-Rate and Subsidized Houses by

Neighborhood.

3.3. Block Rating for Sampled Market-Rate and

Subsidized Houses by Neighborhood. 


\section{List of Figures}

1.1. Albina Community/Study Site. 15

1.2. Portland Median Income by Census Tract, American

Community Survey, 1996.

1.3. Portland Poverty Rate by Census Tract, American

Community Survey, 1996.

1.4. Portland Employment Rate by Census Tract,

American Community Survey, 1996.

1.5. Portland Gross Rent by Census Tract, American

Community Survey, 1996.

1.6. Albina Community Parcel Assessment by Square

Foot, RLIS Data, 1999.

3.1. Albina Community Land Use, RLIS 2000.

3.2. Example of Housing Styles Found in Close-In,

Older Albina Neighborhoods.

3.3. Example of Housing Styles Found in Outer, Newer

Albina Neighborhoods.

3.4. Commercial Strips and Centers of the Albina

Community, RLIS 2000.

3.5. Giulietti Model; Example of NECDC Architectural Style. 
3.5. Collins/Andrews Model; Example of NECDC Architectural Style.

3.7. Example of HOST Housing; Three unit development.

3.8. Examples of Common HOST Architectural Styles.

3.9. Example of Habitat Rowhousing Development.

3.10. Study Sample Distribution and Non-Profit Service Boundaries.

3.11. Assessment Value by Square Foot of Albina

Community Parcels (dwellings included), RLIS, 2000.

3.12. Examples of Sampled Subsidized Houses with 1-1.5

Exterior Ratings.

3.13. Examples of Common Minor Repair Needs; Split

Porch Eave and Peeling Eave.

3.14. Examples of Sampled Market-Rate Houses with 1-1.5

Exterior Ratings.

3.15. Examples of Common Minor Repair Needs; Moldy

Roof and Peeling Paint.

3.16. Example of Sampled Unit Blocks with Very Good to Good Ratings. Block elements contributing to a high rating include healthy and abundant street vegetation, absence of litter, and well maintained yards and units. 
3.17. Example of Sampled Unit Blocks with Poor Ratings.

Block elements contributing to a low rating include

a dead tree standing in the background, parts of a

vehicle litter a residents lawn, and over all run down

state of units on the block.

3.18. Market-Rate and Subsidized Sampled Housing and

Proximity to Neighborhood Amenities.

3.19. Neighborhood Crime Rates and Market-Rate and

Subsidized Sampled Housing Distribution.

3.20. Distribution of Market-Rate and Subsidized Sampled

Housing with Proximity to Portland's CBD.

60 


\section{Chapter I. Introduction}

"We all eat quite enough, and some of us drink a great deal too much, but this I will venture to say, that no man can be too well housed."

- from James Hole's The Homes of the Working Class

Housing embodies much more than just a physical commodity. In addition to being an investment, it is our shelter, right to privacy, connection to community, and access to recreation and necessities. "As in the English language there is no word more tender than that of "home," so there is nothing which implies more misery and desolation than to say of a man he is homeless" (Hole, 1866).

Many programs targeted at improving the lives of low to moderate-income families focus their efforts on improving the quality of affordable housing. Homeownership has long been hailed by social and housing advocates as an economic stabilizer for low to moderate-income neighborhoods. During his administration, President Clinton demonstrated federal commitment of homeownership by establishing the National Home Ownership Strategy. In a speech to the White House Conference on Community Empowerment, given in 1996, Clinton told attendees, "Homeownership is one of the best ways to empower local residents, to give them a stake in the community, and to increase the bonds that tie people together" (US Department of Housing and Urban Development, 1996). 
For low to moderate-income residents (households earning $50-100 \%$ of the median income), homeownership is possible in two forms: affordable market rate housing created by the filtering down of houses until affordable to low to moderateincome households, or through subsidized homeownership programs which develop new housing and offer financial assistance for low to moderate-income households. While the benefits of subsidized new and rehabilitated housing for low and moderate-income households are obvious, the level at which they surpass the quality of comparably priced market rate housing is not.

Developing new housing at costs low enough to sell at affordable prices to low to moderate-income level households may sacrifice amenities otherwise offered by houses that have become affordable through the filtering process. Limited development funds for new subsidized housing may restrict the size and style diversity of houses available. Tight budgets may dictate the use of lower quality materials during construction, increasing the rate at which subsidized houses deteriorate. Locational considerations, such as proximity to public transportation lines, jobs, and retail centers, may be limited if the site location of subsidized houses is restricted to less appealing properties. Limited funds may also determine the quality of the environment in which the new housing unit is located; the newly developed unit may be in perfect condition while the houses it is surrounded by are dilapidated or deserted. 
Does subsidized housing surpass the level of quality found in comparably priced, market-rate housing? Or, do subsidized houses sacrifice physical quality and amenities because of limited development funds? This study will attempt to answer these questions and assess the level of quality offered to low to moderateincome homebuyers. Through an examination of the characteristics of both structural and environmental quality in affordable housing of both filtered and subsidized houses, the objective is to determine which method provides higher quality owner-occupied affordable housing. Systematically examining the characteristics of these two housing types will provide insight into the homeownership options offered to low to moderate-income households and determine if one method is providing higher quality housing. If results indicate that subsidized housing is providing higher quality homeownership options, as should be the case, then it is providing needed services. However, if filtered housing is of overall higher quality, current policies in affordable homeownership programs may need to be reexamined.

The study will first focus on the process of filtering: how it works, the evolution of its study, and its major criticisms. Then, discussion of subsidized housing will reveal its role and criticisms in providing low to moderate-income affordable homeownership opportunities. After comparing both means of homeownership for low to moderate-income households, a description of the study site, Portland's Albina Community, and reasons for selection will be examined. 
The study will then explain methods for empirical comparison of the two housing types. Finally, the results will determine which method, filtering or subsidized, offers low to moderate-income households higher quality homeownership options in Portland's Albina Community.

\section{Home Ownership for Low to Moderate-Income Households}

\section{The Filtering Process}

The basic concept of filtering can be applied to either houses or households.

The filtering down of houses is based on a depreciation of value, resulting from adjustments in perceived quality. Adjustments in perceived quality generally occur when new, high quality houses are added to the total stock. Households filter up based on their desirability to move into higher quality housing, or they can filter down if changes in household income occur. Households can also filter up or down with out moving or changing income if the surrounding neighborhood filters up or down.

Literature on the filtering process is extensive because of the complexity of the process (Baer and Williamson, 1988). The concept of "filtering" has been recognized as a process of housing for several centuries. In James Hole's The Homes of the Working Class, he discusses filtering as a possible solution to increasing the quality of housing among second and third class households. Hole suggests increasing the supply of first class housing, and allowing existing high 
quality housing to filter down, thus ultimately improving the standards of housing for middle and low to moderate-income households (Hole, 1866). While Hole is discussing this concept as a potential solution to decreasing the substandard housing conditions of the industrial worker during the mid 1800s, the formal filtering discussion lies largely in the classical ecological studies of the 1920s (Park, 1925; Bourne, 1981; Leven et al., 1976). Park, Burgess, and McKenzie introduce the notion that concentric rings composed of increasingly newer structures radiate outward from the city center, creating a filtering effect as buildings age and high income households move outward to newer rings of houses (Parks et al, 1925). It is not until 1939, however, that the concept was first explored empirically in Hoyt's Structure and Growth of Residential Neighborhoods in American Cities. Hoyt expanded the concentric ring theory of filtering developed by Park, Burgess, and McKenzie by narrowing the focus to individual houses (Berry, 1979; Bourne, 1981; Leven et al, 1976; Baer and Williamson, 1988).

In 1949, Ratcliff introduced a social element to the discussion of filtering (Ratcliff, 1949; Salins, 1980; Bourne, 1981; Leven et al, 1976). The key to improving low to moderate-income housing was in the rate of new housing production, however, because filtering could not be controlled, it was not a viable solution to improving housing conditions of lower income households. "It is apparent that filtering is a totally inadequate remedy for the acute problem of 
substandard housing. Filtering cannot be forced; it is not a controllable device. The end product of filtering, at the bottom of the chain reaction, is substandard housing; thus filtering produces the very blight that we seek to remedy" (Ratcliff, 1949). Ratcliff further stated that if we were able to accelerate the rate of filtering to the point which it was a viable solution to substandard housing, the rate at which we would be reducing the value of higher income housing to sustain the affordability of higher quality housing for low to moderate-income households would be "tremendous" (Ratcliff, 1949; Kristof, 1972). In addition to widespread depreciation of housing values, Lowry argues induced filtering would also reduce the level of maintenance in higher quality houses in response to declining appreciation (Lowry, 1960; Kristof, 1972).

Subsequent studies in the realm of filtering explored the social element aspect of the process. These studies either supported Ratcliff's claim that stimulating the filtering process was an insufficient approach to increasing the quality of low to moderate-income housing or adhered to the belief that with proper policies, filtering would improve substandard housing.

Kristof's discussion of filtering cites Grigsby's discussion of exogenous factors which needed to be accounted for before discrediting filtering as a method for increasing the level of quality in low to moderate-income housing (Kristof, 1972). For filtering to increase the quality of low to moderate-income housing, new construction must exceed population growth, exerting a downward pressure on 
rents that does not exceed the downward pressure on quality, while a mechanism is in place to remove the substandard housing at the bottom without affecting rents (Kristof, 1972; Berry, 1979). Further discussion of filtering cannot happen without acknowledgement of these factors. While Kristof's study of vacancy chains in New York supports the process of filtering as an agent in increasing the level of quality housing available to lower income households, he maintains that direct subsidies to low to moderate-income families to maintain the structures they live in would provide a better mechanism to increase the quality of low to moderateincome housing than would the subsidization of new construction (Kristof, 1973). Providing low to moderate-income families with higher quality housing won't help improve the quality of housing stock if these households don't have the means to maintain them (Lowry, 1960; Kristof, 1973; Edel and Rothenberg, 1972).

The study of the effect of filtering through the chain of moves was also investigated in several other studies. Lansing, Clifton, and Morgan's survey of households that had moved found that the majority of households move to improve their housing conditions, and if not to improve the physical condition, to improve the location in relation to other desired amenities, such as employment. Vacancy chains observed in their study revealed filtering effects are greatest the higher the value of the property, but while minimal, housing does filter down to the poor (Lansing et al, 1969; Marullo, 1985). Berry's study of vacancy chains in Chicago found that blacks had benefited from the white migration to the suburbs, through 
the acquisition of higher quality housing (Berry, 1979). Another study done by Marullo, also found that vacancy chains were highest amongst higher valued properties, but claimed filtering breaks down before reaching those that really need it. In addition, Marullo found that chains amongst rental houses were longest amongst the lowest priced houses (Pipkin, 1983; Marullo, 1983 and 1985).

Discussion of filtering further advanced to include the role of the neighborhood in the process (Salins, 1980; Henderson, 1985; Nourse, 1973). In neighborhood filtering, the quality of a unit is not based solely on its physical condition, but also its architectural style and surrounding neighborhood condition (Salins, 1980; Henderson, 1985). In well maintained neighborhoods, age does not contribute to the downward filtering of the area when properties are properly maintained and the neighborhood retains its attractiveness to upper income households (Salins, 1980). Little's study of neighborhood filtering provided strong evidence that neighborhoods are influential in the locational decision of a homebuyer (Little, 1976). Residents may "experience a change in utility" when the neighborhood conditions change without the move of a household, a phenomena termed "passive filtering". Neighborhood filtering then is the process by which a neighborhood changes in relation to other neighborhoods in its level of desirability (Little, 1976; Henderson, 1985; Leven et al., 1976).

Finally, additional research on the filtering process has shown that while houses filter down, they may also filter up. The desirability of a unit is affected by 
its vintage attractiveness (Myers, 1983) and by its location (Maher, 1974). This effect is commonly referred to as gentrification, where older houses are bought by higher income groups and renovated, altering the number of filtered houses available for lower income households.

Filtering as housing policy has been controversial. While some studies support the notion that filtering benefits do reach lower income households, many consider these benefits minimal and regard the reliance upon filtering to provide higher quality low to moderate-income housing as inadequate (Bourne, 1981; Edel 1972; Galster, 1996; Marullo, 1983; Weicher and Thibodeau, 1988). Even if housing is able to reach lower income households through filtering, many fear they will be unable to afford the maintenance required on filtered houses (Colean, 1947; Lowry, 1960; Kristof, 1973; Edel and Rothenberg, 1972; Nourse, 1973).

Another criticism of filtering as a means to improving low to moderateincome housing quality includes the inability of filtered housing to meet differing needs of those that inherit it. Inherited housing may not meet size requirements or may require more maintenance than the new owner is able to afford (Colean, 1947; Baer and Williamson, 1988).

\section{Subsidized Housing}

Instead of leaving the improvement of the quality of low to moderateincome housing up to the natural or induced filtering of the market, many advocate 
directly subsidizing new or renovated affordable housing for middle and low to moderate-income groups (Colean, 1947; Smith, 1970; Edel and Rothenberg, 1972; Marullo, 1985; Marullo 1983). Currently, the majority of housing subsidies are through tax credits, low interest mortgage financing, and grants at both the supply and demand ends. On the supply side, the federal government most often subsidizes high income new housing through tax credits rather than directly subsidizing new housing or renovations directed at middle to low to moderate-income households (Kristof, 1972; Bourne, 1981; Edel and Rothenberg, 1972; Aaron, 1972; Marullo, 1985).

In the past, new housing that has been built with direct federal subsidies for low to moderate-income households has been criticized as being poorly built (Kristof, 1972; Edel and Rothenberg, 1972) and too expensive. Building subsidized housing is expensive because a large portion of the development costs are lost to private and governmental intermediaries (Kristof, 1972; Quigley, 1999). Deterioration caused by the centralization of federally subsidized housing projects in already deteriorating neighborhoods, high density of houses catering to low to moderate-income families, poor design, and low quality building have created a massive nationwide replacement effort with lower density houses through the HOPE VI program (Cott, 1999).

While many affordable housing developments still receive direct funding from federal, state, and city sources, trends in the 1960s shifted allocation and 
development responsibility to either local non-profit community development corporations (CDCs) or private developers. The rise of CDCs in the sixties originated out of civil rights, advocacy, and religious movements. Most of the agencies at that time were funded through the Ford Foundation's Gray Areas Program. Within a decade, the number of CDCs nationwide went from 100 to 1000 (Gittell and Wilder, 1999). This number grew even larger in the 1980s when the Reagan Administration drastically decreased direct federal spending on housing (Vidal, 1997; Gittell and Wilder, 1999). While CDCs main efforts can be seen in housing, their work extends to a broad range of services such as job training and placement, social services, and community organizing (Sullivan, 1993; Gittell and Wilder, 1999; Vidal, 1997).

The privatization of low to moderate-income housing production fueled partly by negative associations with previously produced public housing has resulted in the near elimination of government produced low to moderate-income housing. Most of the housing that has been produced since the 1970 s with federal subsidies has been built by CDCs and non-profit or private developers (Schill, 1994).

In addition to receiving direct government subsidies, mainly through the Community Development Block Grant (CDBG) and the HOME programs, and indirect federal subsidies through tax breaks and low interest loans, CDCs and private developers fund new housing construction through a variety of sources, 
including subsidies, private corporations, volunteer labor, foundation grants, and individual contributions (Schill, 1994; Vidal, 1997; Rosen and Dienstfrey, 1999). Pierce and Sullivan reported private donations to CDCs between 1970 and 1990 reached \$2 billion dollars (Gittell and Wilder, 1999).

By 1990, over 5,000 CDCs were creating affordable housing for low to moderate-income residents in the United States (Davis, 1995). A survey of CDCs done by Goetz in 1993 revealed $95 \%$ of 133 U.S. cities with populations of over 100,000 had at least one CDC operating in them. Over $90 \%$ of these CDCs develop housing, and the number of houses built by these non-profits is growing steadily annually (Vidal, 1997).

While most agree that CDCs and non-profit developers help create housing in distressed areas (Gittell and Wilder, 1999), there has been criticism. One criticism is that with so much time wrapped in securing funding sources, non-profit developers actually spend more developing housing than for profit developers do. A study done by Abt and Associates showed for profits developing at lower costs than non-profits (Rosen and Dienstrfrey, 1999). In addition to spending more, the study found that non-profits on average spend 30 months developing a project, securing funding and fighting neighborhood opposition. Two other studies done by Sullivan and Bratt and Colleagues found that non-profit developed housing rarely sets aside money for maintenance in later years, and homeowners often can not afford to pay for repairs needed (Sullivan, 1993; Rosen and Dienstrfrey, 1999). 
Today, over $25 \mathrm{CDCs}$ and non-profit housing developers serve the greater Portland metropolitan area. Of these, at least 10 create affordable housing opportunities in the Albina Community neighborhoods. While many only serve the needs of rental housing, several - Human Solutions, HOST, Northeast CDC, and Habitat for Humanity - create home-ownership opportunities for low to moderateincome households (Community Development Network, 2000).

\section{The Study Site}

\section{Albina Community History}

In the 1880 s, Albina was a bustling railroad city independent of Portland. Annexation with the City of Portland occurred in 1891. Migration of wealthier households to the suburbs in the early 1900 s resulted in an in-migration of lowerincome European immigrants (Barnett and Suo, 1996). In the 1930s, many of European immigrants left the area, and African American migration from the South to the area followed (Lyderson, 1996; Barnett and Suo, 1996). Albina has housed Portland's highest concentration of Black residents since the 1940s (Hunsberger, 1998).

From the 1950 s to the early 1990 s, people considered Albina to be Portland's ghetto. Violence, crime, and housing dilapidation were prevalent (Lyderson, 1996; Barnett and Suo, 1996; Fitzgibbon, 2000; Hunsberger, 1998). Efforts in the 1950s and 1960s to clear some of the urban blight included wiping 
out many residential blocks to make way for three major construction projects:

Interstate 5, which runs north/south through the area on the western side, Emanuel Hospital located along Williams and Vancouver Streets, south central to the area, and Memorial Coliseum, located at the base of the Broadway Bridge in the south western corner of Albina (Lyderson, 1996; Barnett and Suo, 1996). The 1970s and 1980s saw further decline in the area resulting in disinvestment from local lending agencies and abandonment. Banks refused to lend to even stable residents in the area believing the houses would not hold their value (Fitzgibbon, 2000).

Recent years have shown signs of change. In 1993, the Albina Community Plan was adopted after three years of planning. This was the first community wide effort created to fight growing unemployment, poor housing, economic disinvestment, and inadequate transportation (City of Portland, 1993; Fitzgibbon, 1999; Fitzgibbon, 2000). In 1990, the City of Portland's Bureau of Buildings counted 700 derelict buildings in the area; in 1996, there were only 100 (Barnett and Suo, 1996). While many of the homes in 1990 were selling for $\$ 10,000$ to $\$ 30,000$ (Barnett and Suo, 1996), prices in the area reportedly doubled between 1984 and 1995 (Barnett and Suo, 1996; Behrs, 2000). A study of the 2000 of area's new homes done by the Oregon Title Company in 1997 found only $2.4 \%$ were sold for under $\$ 125,000$ (Hunsberger, 1998).

CDCs and non-profit housing developers began investing in the area as early as 1984 with the establishment of the former Northeast Community 
Development Corporation. Since then, CDCs and non-profit developers have created or rehabilitated over 1000 affordable houses. Of these houses, over one third are owner occupied (Community Development Network, 2000).

\section{Albina General Characteristics}

Bordered by the Columbia River to the north, the Willamette River to the west (including Swan Island), NE Broadway and NE Prescott to the south and NE $26^{\text {th }}$ and NE $42^{\text {nd }}$ to the east, Portland's Albina Community binds thirteen neighborhoods and two industrial parks (Figure 1.1).

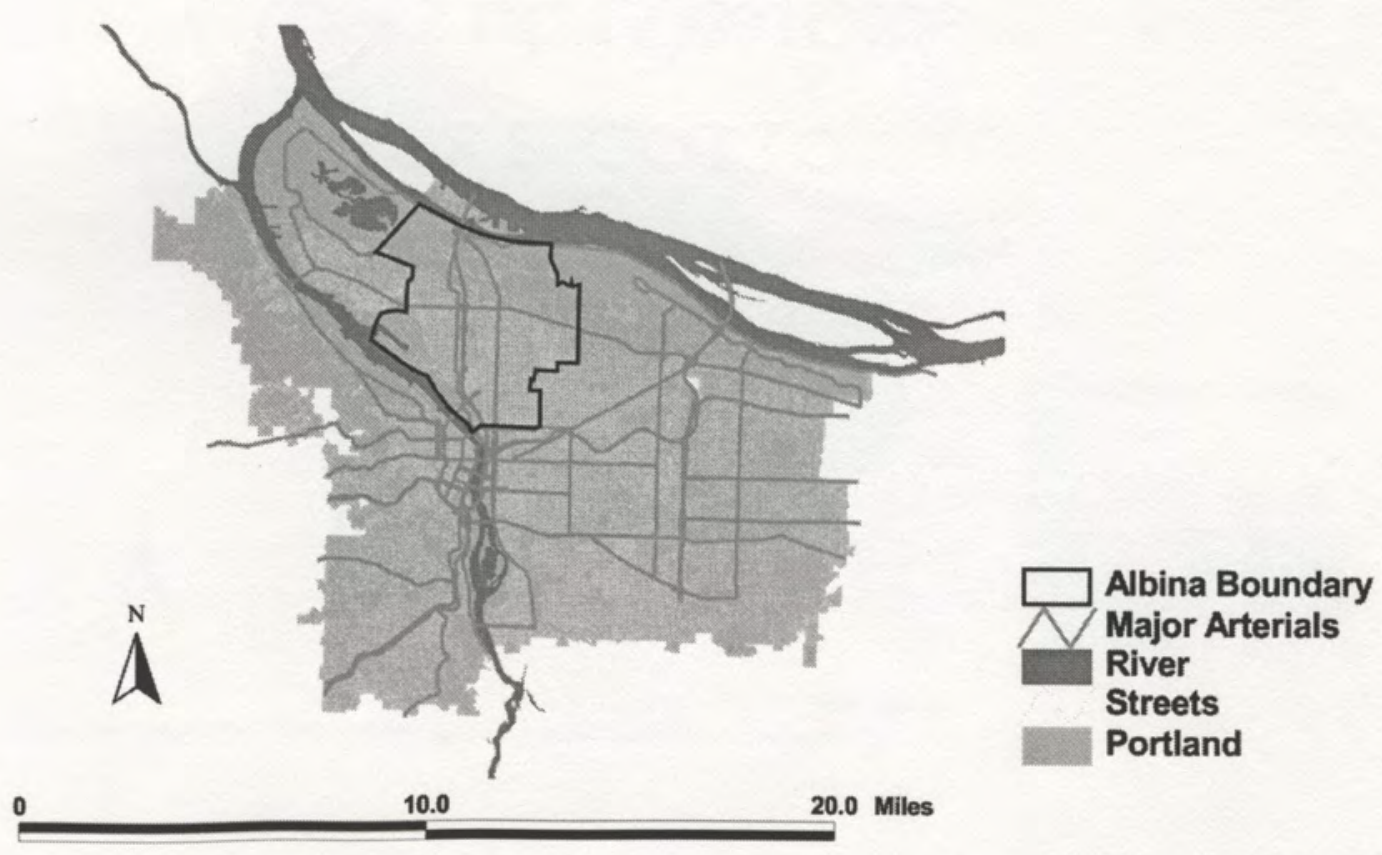

Figure 1.1. Albina Community/Study Site. 
The Albina Community is an ideal area to study market rate and subsidized affordable housing quality for several reasons. First, the area has been targeted by government and non-profit efforts in the past decade as an area in need of revival. Secondly, the area is comprised largely of low and middle-income residents. American Community Survey data for 1996 show about one third of the area in the lowest bracket of household income for the City of Portland, with most of the remaining census tracts in the second lowest income bracket (Figure 1.2).

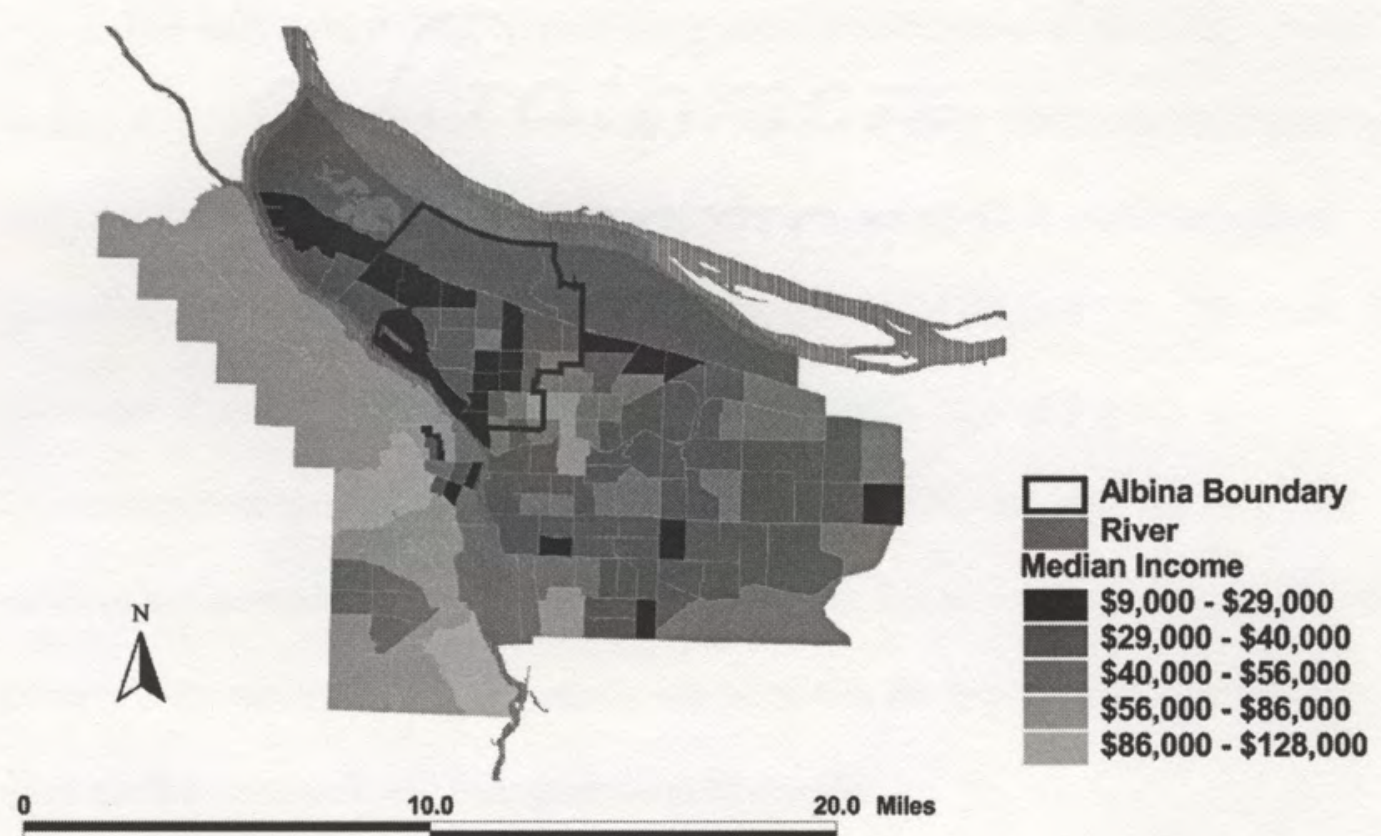

Figure 1.2. Portland Median Income by Census Tract, American Community Survey, 1996. 
Albina contains the highest concentration of census tracts in the lowest income distribution. Only three census tracts in Albina fall into a higher rank than $\$ 40,000$. Two of these tracts, one found in the Woodlawn neighborhood and the other in the Concordia neighborhood represent median incomes between $\$ 40,000$ and $\$ 56,000$. The other tract, in the Irvington neighborhood, represents households with incomes between $\$ 56,000$ - $\$ 86,000$. Few of Portland's census tracts have incomes that high or higher. Areas that do are concentrated in the Irvington and Alameda neighborhoods in the center of Portland, and on the West side of the Willamette River.

Not only does Albina contain the highest concentration of the City's lowest income distribution, American Community Survey data for 1996 indicates that over half of the Albina Community's census blocks are among those with the highest percentages of households living below the poverty level (Figure 1.3). The only other area showing a similar significantly high concentration of poverty is Downtown Portland, where the majority of the City's SRO housing and homeless services are located. Most of Albina's census tracts fall within the highest ranks of poverty distribution. The two areas in Albina within the lowest bracket of poverty rates are the Overlook and Irvington neighborhoods. 


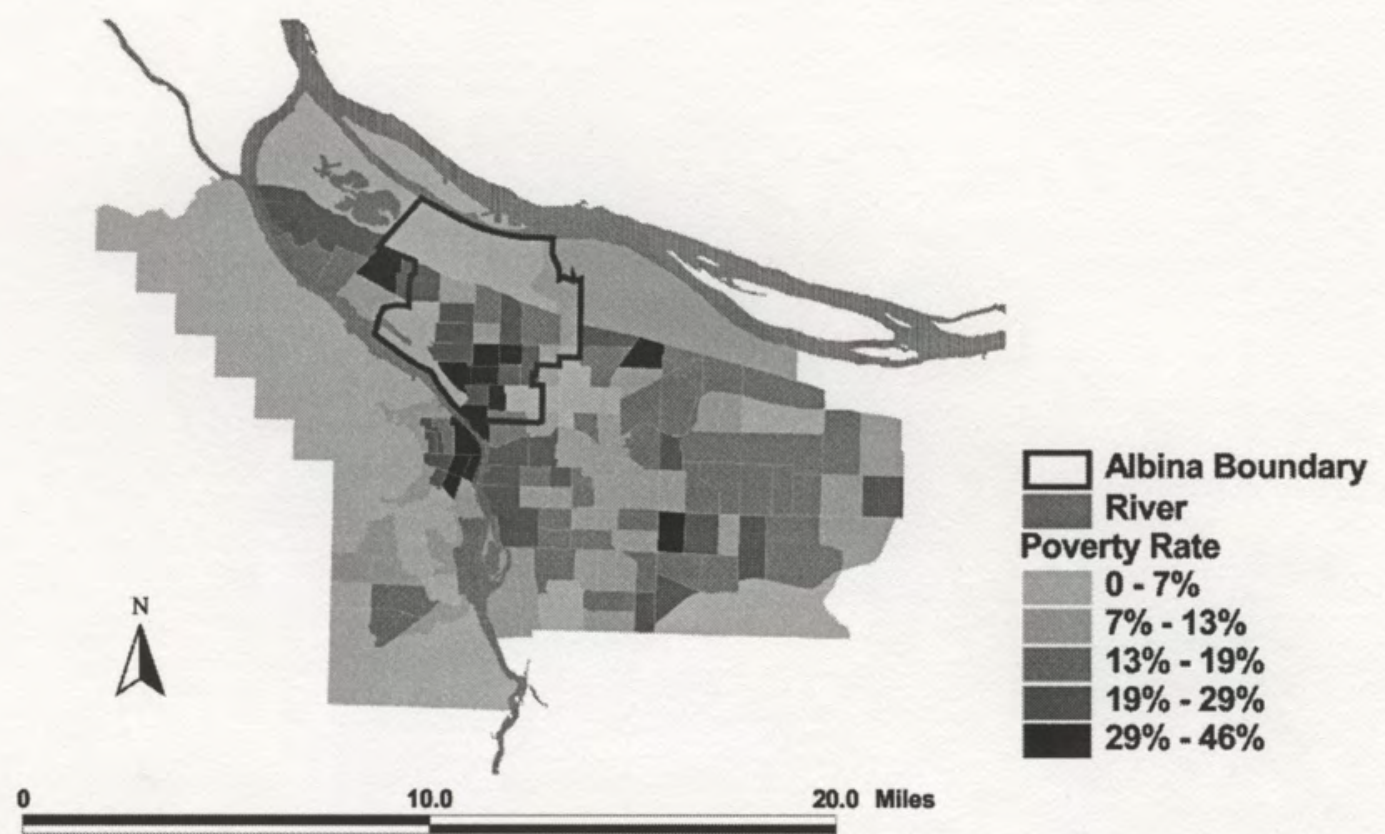

Figure 1.3. Portland Poverty Rate by Census Tract, American Community Survey, 1996.

Another indication that Albina has a high number of low and middle-income residents is evident in the area employment rates (Figure 1.4). Census tracts in Albina have some of the lowest employment rates in the city. Most of the city falls into the middle employment rate bracket, with distribution dominating a path through the center of the city. The southeastern corner of the city also indicates similarly low employment rates. 


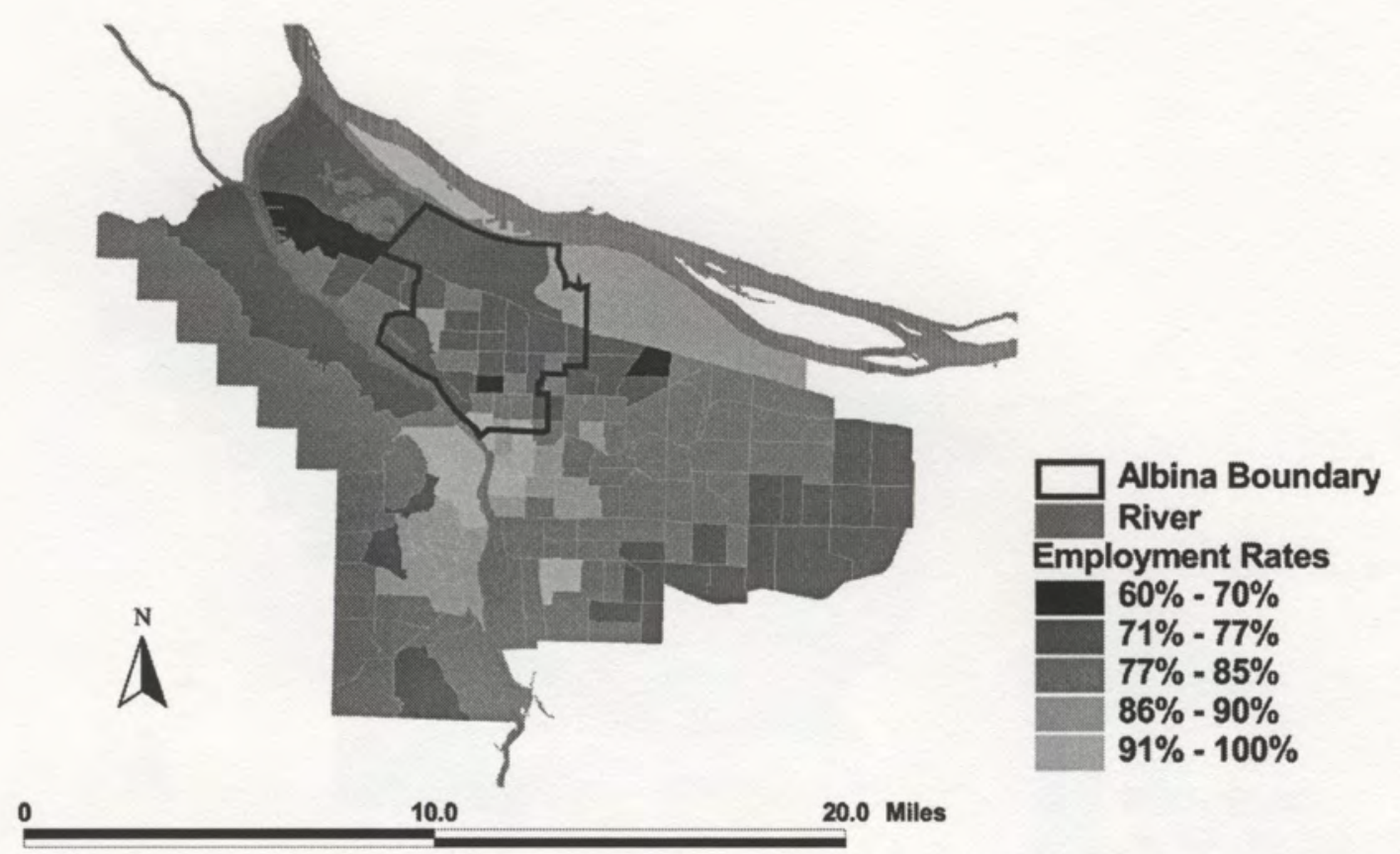

Figure 1.4. Portland Employment Rate by Census Tract, American Community Survey, 1996.

A third reason Albina is an optimal site for the study of low to moderate-income homeownership is because the area is considered one of the most affordable areas to live in the city (City of Portland Bureau of Planning, 1993). Gross rents at the census block level indicate over half of the area pays some of the lowest rent rates in city (Figure 1.5). Almost all of Albina's census tracts are distributed among the lowest three rental distributions. Two thirds of these tracts are within the lowest two rankings of rents. While the rest of the city is scattered in it's range of rent distributions, rent distributions for Albina indicate it is constantly cheaper overall. 


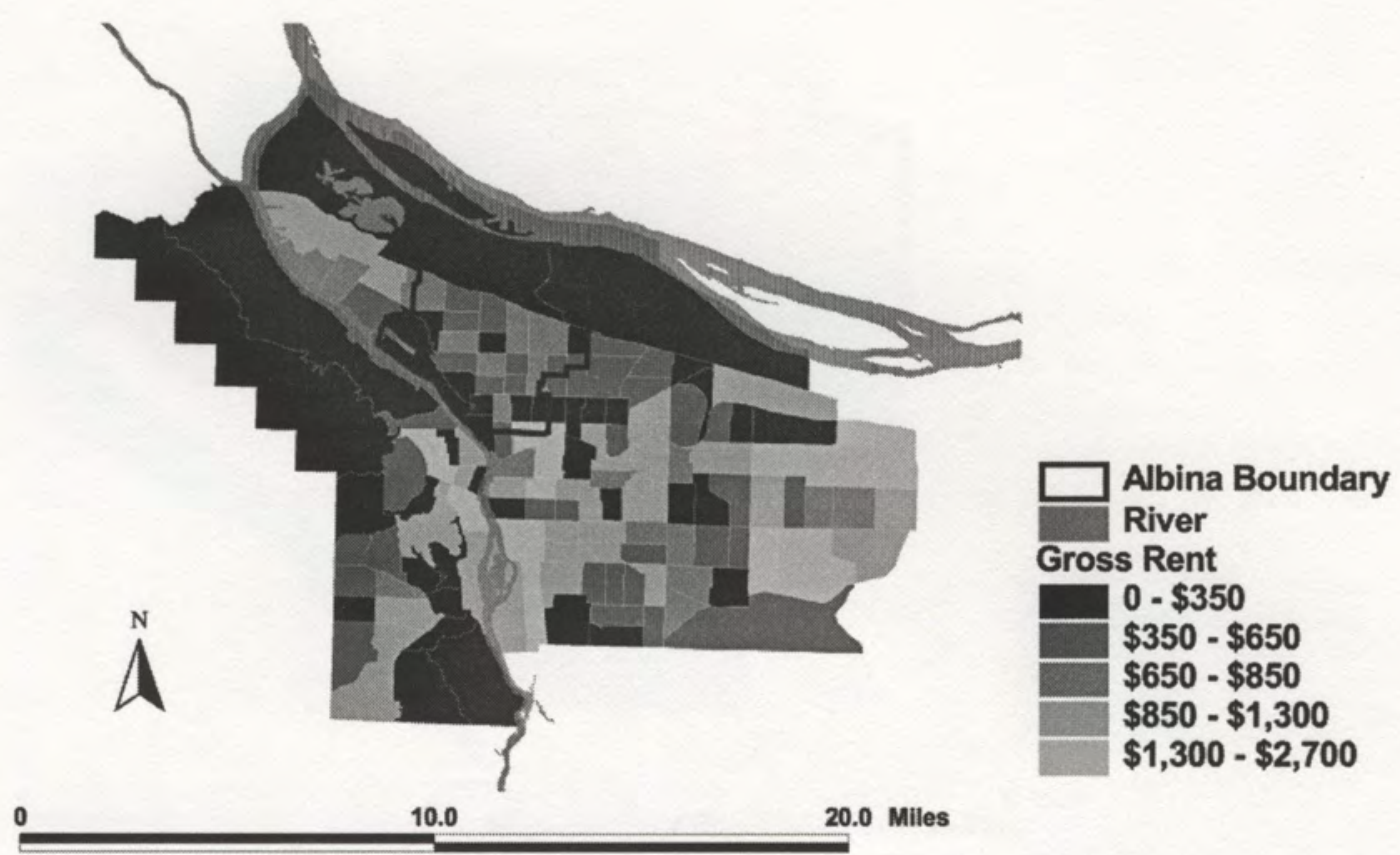

Figure 1.5. Portland Gross Rent by Census Tract, American Community Survey, 1996.

A closer look at the site shows that assessment values of residential parcels in Albina reflect large clusters of parcels assessed at $\$ 80,000$ and lower (Figure 1.6). The center of the site is dominated by the lowest distribution of assessment values. Few residential parcels are assessed above $\$ 180,000$. Moving north, values increase somewhat but are still dominated by the lowest two value brackets. Highest values can been seen in the south western and south eastern corners of the site, in the Irvington and Overlook neighborhoods, where income levels were higher. 


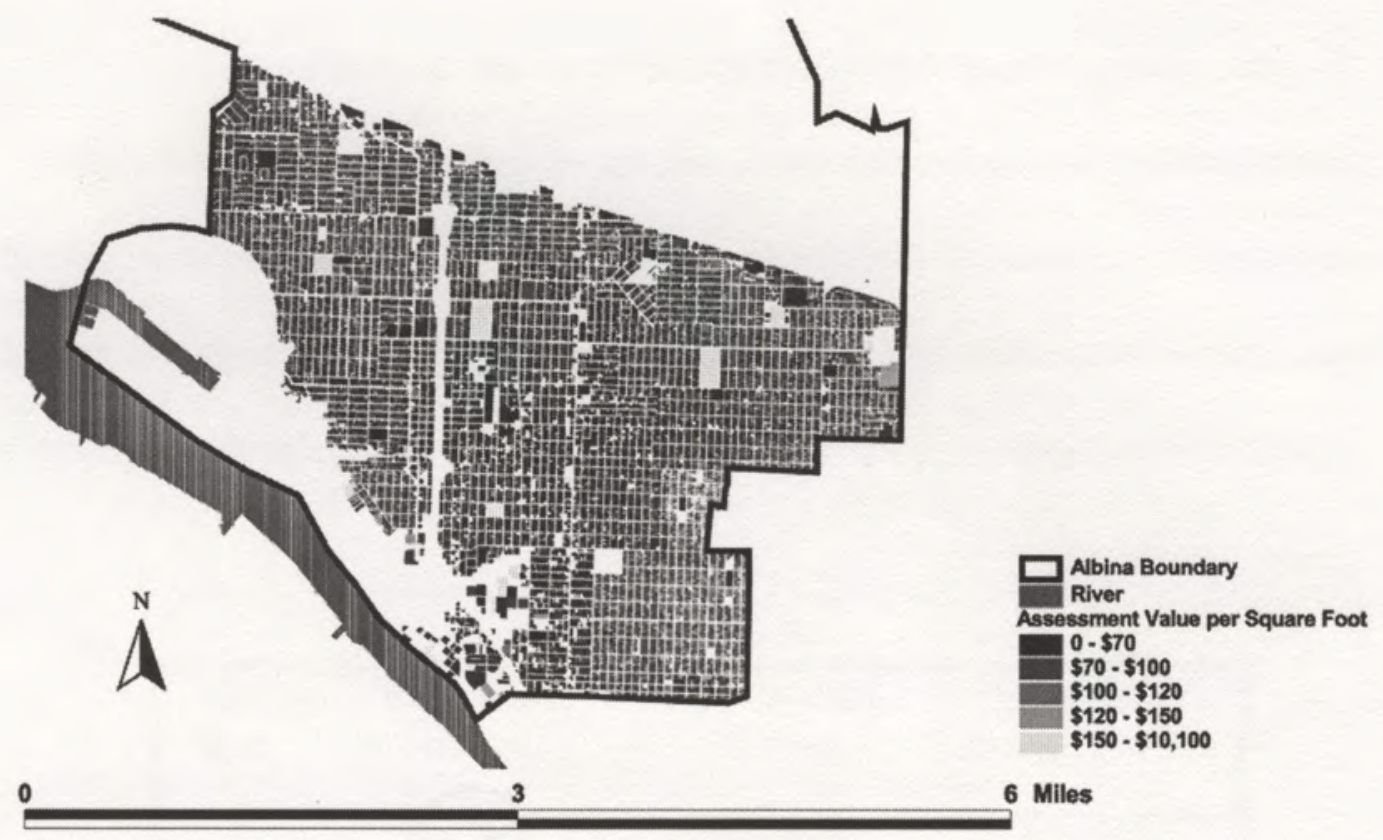

Figure 1.6. Albina Community Parcel Assessment by Square Foot, RLIS Data, 1999.

Finally, as the target of numerous $\mathrm{CDC}$ efforts and community planning, the Albina Community is an ideal environment for the observation of subsidized examples of owner-occupied affordable housing. The latest guide to CDCs and nonprofit housing developers released by the Community Development Network indicates that at least 371 houses of owner-occupied housing have been created in the Albina Community. This constitutes over $80 \%$ of all owner-occupied housing created in the City of Portland by CDCs and nonprofit housing developers (Community Development Network, 2000). 


\section{Chapter II. Methodology}

Two sets of houses, one consisting of market-rate houses and the other of subsidized houses, were randomly sampled to test and compare affordable housing quality in the Albina Community. The market-rate housing sample was determined by calculating affordability based on the City of Portland's Bureau of Housing and Community Development (BHCD) household income guidelines for 2000 (Table 2.1).

\begin{tabular}{|cccc|}
\hline $\begin{array}{c}\mathrm{HH} \\
\text { Size }\end{array}$ & $\begin{array}{c}\text { Very Low } \\
\text { Income } \\
(30 \%)\end{array}$ & $\begin{array}{c}\text { Low Income } \\
(50 \%)\end{array}$ & $\begin{array}{c}\text { Moderate } \\
\text { Income }(80 \%)\end{array}$ \\
\hline 1 & $\$ 11,300$ & $\$ 18,800$ & $\$ 30,050$ \\
2 & $\$ 12,900$ & $\$ 21,500$ & $\$ 34,350$ \\
3 & $\$ 14,500$ & $\$ 24,150$ & $\$ 38,650$ \\
4 & $\$ 16,100$ & $\$ 26,850$ & $\$ 42,950$ \\
\hline
\end{tabular}

Table 2.1. Household Income Guidelines, City of Portland Bureau of Housing and Community Development, 2000.

Income figures for 30,50 , and $80 \%$ are calculated from the Portland median income for the year 2000. The income categories shown in Table 2.1 are the standard income classifications used by the city when computing income eligibility for income specific programs. 
Paying no more than a third of one's household income on housing, the maximum price affordable to the highest earning income group is $\$ 125,000^{1}$. This price is based on a 30 -year term mortgage at a $7 \%$ interest rate with a minimum $5 \%$ down payment. The market-rate sample was a $25 \%$ sample of houses that sold in the Albina Community priced at $\$ 125,000$ or lower during the year 2000 . While houses priced at $\$ 125,000$ may not be affordable to households earning less than $\$ 42,950$, selecting that figure increased the diversity of the original data set, ultimately creating a sample more representative of Albina's affordable market-rate housing. Housing sale data was obtained from the Oregon Title Company. The original data set was roughly 400 houses.

The subsidized housing data was sampled from houses built by the former Northeast Community Development Corporation (NECDC), Homeownership One Street at a Time (HOST), and Habitat for Humanity. NECDC was the oldest CDC in the Albina Community, as well as one of the oldest in the city (Community Development Network, 2000). Funded largely through a HUD Nehamiah grant of $\$ 3.75$ million, NECDC built 200 houses, most of which are owner occupied (Rubenstein, 1999; Oliver, 2000). NECDC's homeownership program renovated older houses and built new houses which were made affordable through county donated tax foreclosed parcels in their service district, low interest loans, and

\footnotetext{
${ }^{1}$ This number was calculated using an online mortgage calculator through the Oregonlive Homefair site, which factored in a rate of $1 \%$ for property taxes and $.5 \%$ for hazard insurance.
} 
waived city development fees (Rubenstein, 1999; Faulstich, 1996). Homeowners qualified for the program if they made under $80 \%$ of the median income. A second mortgage to the homeowner of $\$ 15,000$ increased the affordability and was forgiven until point of sale, lease, or transfer of property (Faulstich, 1996). In August of 2000, NECDC went bankrupt as the result of failed for profit investments and withdrawn support from the city (Oliver, 2000).

HOST is not a CDC, but a non-profit real estate agency, devoted to "providing affordable housing while revitalizing deteriorating neighborhoods" (Potter, 1997). The non-profit developer builds new housing, generally placing two or more houses per block at a time. HOST caters to $80-100 \%$ of the median income, offering only homeownership housing. HOST does not receive government subsidies, but relies on revenue from house sales and private contributions. HOST's homeownership program requires that houses remain owner occupied, and that owners maintain the property, attend homeowner education classes, and donate 50 hours of community service each year for five years. Each participant receives a $\$ 5,000$ grant to cover the down payment and closing costs of the purchased home which is forgiven the owner stays in the house for five years (Potter, 1997).

Habitat for Humanity is also not a CDC, rather a faith based non-profit developer that relies on charity and volunteer labor rather than government subsidies to fund its operation. Private corporations donate up to $40 \%$ of the 
materials used to build Habitat housing (Dunnett, 1997). Habitat sells houses at for-cost development prices, with a no-interest 25 year mortgages (Oregonian, 1998; Dunnett, 1997). The Habitat program is unique because it requires the homeowner to provide 400 hours of sweat equity in the construction of their new home. Owners that choose to sell must provide Habitat with the first rights to the sale and only receive a portion of the equity per year until they have fully paid off the mortgage (Dunnett, 1997).

All three of the housing providers offer their properties under the ten year tax abatement program and each has received county donated tax foreclosed parcels to build their houses on (Potter, 1997; Dunnett, 1997; Rubenstein, 1999). The tax abatement program increases the affordability of owner-occupied housing by granting a 10-year property tax abatement on improvements as long as the appraised value does not exceed $120 \%$ of the area's median sale prices. In its early days NECDC had sole rights to foreclosed parcels in their service district. However, in the past few years all three developers, in addition to other operating CDC and non-profit developers in the area, have had to compete for foreclosed parcels, which have dwindled in number as the area has improved.

Houses for the subsidized data sample were randomly sampled at $33 \%$ from a data set of about 300. Sale dates for these dwellings ranged from 1994 to 2000 . Sale prices from 1994 to 1999 were adjusted to reflect their current housing market 
value by calculating the rate of inflation based on the area's housing sale history (Table 2.2).

\begin{tabular}{|lcccccc|}
\hline Year Sold & 1994 & 1995 & 1996 & 1997 & 1998 & 1999 \\
\hline Rate Adjusted & 0.54 & 0.40 & 0.28 & 0.17 & 0.09 & 0.05 \\
\hline
\end{tabular}

Table 2.2. Sale Adjustment Rates Based on Repeat Sales Reported, Real Estate Report, Spring 1996, 2000 and $2001^{2}$.

The first part of this analysis involved examination of both samples' structural characteristics. Housing size, sale price, cost per square foot, and age were compared to determine the differences and similarities between the two groups of housing. If subsidized housing is providing higher quality houses at lower than market-rate prices, subsidized houses should be cheaper per square foot than the sampled market-rate houses. After comparing general structural characteristics, the physical quality of the structures and neighborhoods were examined.

Housing quality, for the purpose of this study, is defined as the physical condition of the house and the characteristics of the neighborhood in which it is located. Examining the structure alone would be meaningless without also

\footnotetext{
${ }^{2}$ In order to level differences in sale prices between market-rate houses sold in 2000 and subsidized houses sold between 1994 and 1999, subsidized sale prices were adjusted by multiplying average rates of price increases in housing sales for each year. Rates were computed by first averaging the average sale price for North and Northeast Portland houses in 1993, 1994, 1995, 1996, 1997, 1998, 1999 , and 2000, and then calculating the rate at which the average price increased between each year.
} 
examining its surrounding environment. Housing quality is both influenced by and an indicator of neighborhood conditions. Anthony Downs cites physical deterioration and the loss of confidence among investors and property owners as two critical components of neighborhood decline, while neighborhood revitalization is the result of improved physical conditions, rising property values, and renewed confidence among investors and property owners. Homeowners are highly motivated to invest in their house based on their estimate of the dwelling's long term value, which is dependent upon the neighborhood's potential for recovery, or decline, and the investment seen in neighboring properties (Downs, 1980).

Realtors have long understood that location is part of the housing bundle; as housing prices decrease, so does the perception of the quality of the surrounding environment. Hickman, Gaines, and Ingram's study of neighborhood quality influence on residential property values found that location may be the single most influential factor in property value (Thibudeau, 1997; Hickman, Gaines, and Ingram, 1984).

The interdependence of housing and neighborhood conditions is also acknowledged by planners and policy makers. In 1988, the City of St. Paul, Minnesota surveyed one sixth of their housing stock to get a sense of the city's housing conditions and through the assessment of the housing conditions, determine the overall condition of their neighborhoods (City of St. Paul, 1988). 
Under the same premise, R.K. Piper surveyed both housing and neighborhood conditions in Lincoln, Nebraska to assess where federal block grant money should be applied (Piper, 1985).

To show the difference in quality between market rate and subsidized housing, a variety of housing and neighborhood attributes based on measures drawn from the housing and neighborhood quality literature were examined. Assessment of quality was achieved by weighing these attributes under two distinct categories: structural condition and neighborhood characteristics. Combined, these two categories define the level of housing quality that is available to low and moderate-income level households in both market-rate and subsidized housing. If subsidized houses are truly able to provide higher quality houses by building new, these houses should reflect better structural quality than those houses available on the market.

Exterior structural quality was determined for each house by field observation. Based on the model used by the St. Paul Planning Department to survey housing stock quality, this method numerically rates the exterior condition of the house. Seven variables were evaluated in the housing quality rating: roof, eaves, walls, windows, doors, porch, and yard. Each variable received a score of 1 through 5 with 1 being in sound condition with no need for repairs to 5 being severely dilapidated and in need of substantial repair (City of St. Paul, 1988). Scores were then combined and averaged to reflect one score for each house. 
Photographs taken of houses surveyed exhibit the surveyor's interpretation of this rating model (see Appendix A).

Neighborhood quality was assessed by examining eight variables derived from several similar studies. R.K. Piper used the presence of heavy traffic, litter, and yard junk, as well as the condition of streets, street lights, vegetation, curbs, sidewalks, storm drains, and yards to evaluate what he termed "environmental" and “capital" elements of block conditions in Lincoln Nebraska (Piper, 1985).

Greenberg, Scheinder, and Choi's study of neighborhood quality indicators found that residents rated their neighborhoods poor when the following characteristics were found in their neighborhoods; non-residential land use, vehicle noise and heavy traffic, litter, streets in disrepair, poor building conditions, crime, traffic congestion, and industrial processing plants. Their study also found that neighborhoods received high ratings when they were within proximity leisure activities, good schools, public services, public transportation, and shopping, to name a few (Greenberg, Scheinder, and Choi, 1994). Another study, by Kain and Quigley, found that neighborhood quality was low when density of commercial and vacant lots was high, and the number of bad housing and overcrowded houses was high (Kain and Quigley, 1970).

Based on these studies, variables selected to determine neighborhood quality in this study included: physical characteristics of each block, proximity to neighborhood amenities including retail centers, major grocery stores, public 
transportation lines, schools, and parks, neighborhood crime rates, and proximity to the CBD. Physical characteristics of each block were evaluated based the following conditions. The state of vegetation, condition of roads, curbs, and sidewalks, presence of litter, location on a major arterial, and overall condition of nearby houses on the block, were all scored in a similar fashion to exterior structure quality. Each block received a score between 1 and 5, with 1 representing excellent conditions and 5 reflecting very poor conditions.

Proximity to neighborhood amenities - retail centers, major grocery stores, public transportation lines, schools, and parks - were evaluated using GIS to measure the distance from each unit in the sampled data set to each amenity. A standard maximum walkable distance of 400 meters was used to assess desirable proximity (Aultman-Hall, Roorda, and Baetz, 1997). Analysis of proximity to these amenities involved a comparison between the amenities found within $1 / 4$ mile (400 meters) of market-rate and subsidized houses.

Neighborhood crime rates for a six-month period in 2000 were obtained from the City of Portland Police Bureau and then mapped at the neighborhood level and analyzed in relation to crime rates for the entire Albina Community. Analysis of the distribution of the two samples per neighborhood with respective to crime rates to will determine if either are located at a higher frequency in crime ridden neighborhoods. 
Proximity to Portland's CBD was measured with GIS. This variable has been included because it reflects a large area of potential employment opportunities. Analysis involved comparing the two samples distribution per neighborhood with proximity to Portland's CBD to determine if either are located at a higher frequency closer to Portland's vital white-collar employment center. 


\section{Chapter III. Results}

\section{Area Characteristics}

The study area was comprised largely of single-family residential dwellings (Figure 3.1).

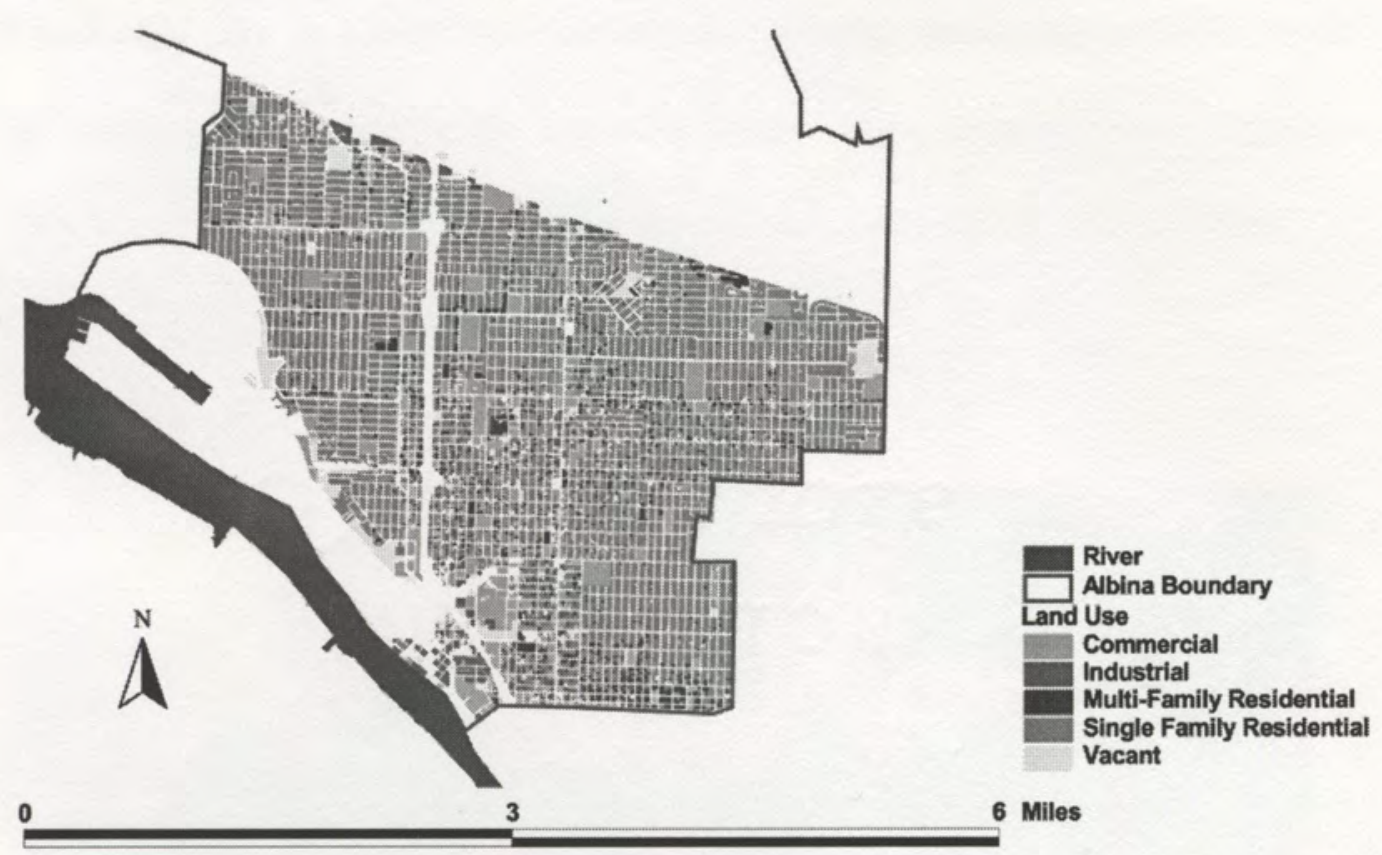

Figure 3.1. Albina Community Land Use, RLIS 2000.

A high concentration of commercial and industrial uses exist along the river and western boundaries of Albina, but few of the sampled houses are close to that area. Not shown in this map is an industrial park just northwest of the river, but significantly steep topography divides residential areas from this industrial island. Also, the northern edge of the area borders an industrial park not shown in this 
map. Several of the houses in the site are close to that area, but residential units are separated by a major arterial, and units sampled within close proximity are buffered from this arterial by several blocks of primarily residential land use, making its presence impertinent.

The single-family residential dwellings are of diverse architectural styles and sizes. Residential units in Albina located closer to Portland's downtown are older, early $20^{\text {th }}$ century, and in many cases larger dwellings. These units were dominantly Folk Victorian, Arts and Crafts, Bungalow, Dutch Colonial, or Cubic in style (Figure 3.2).

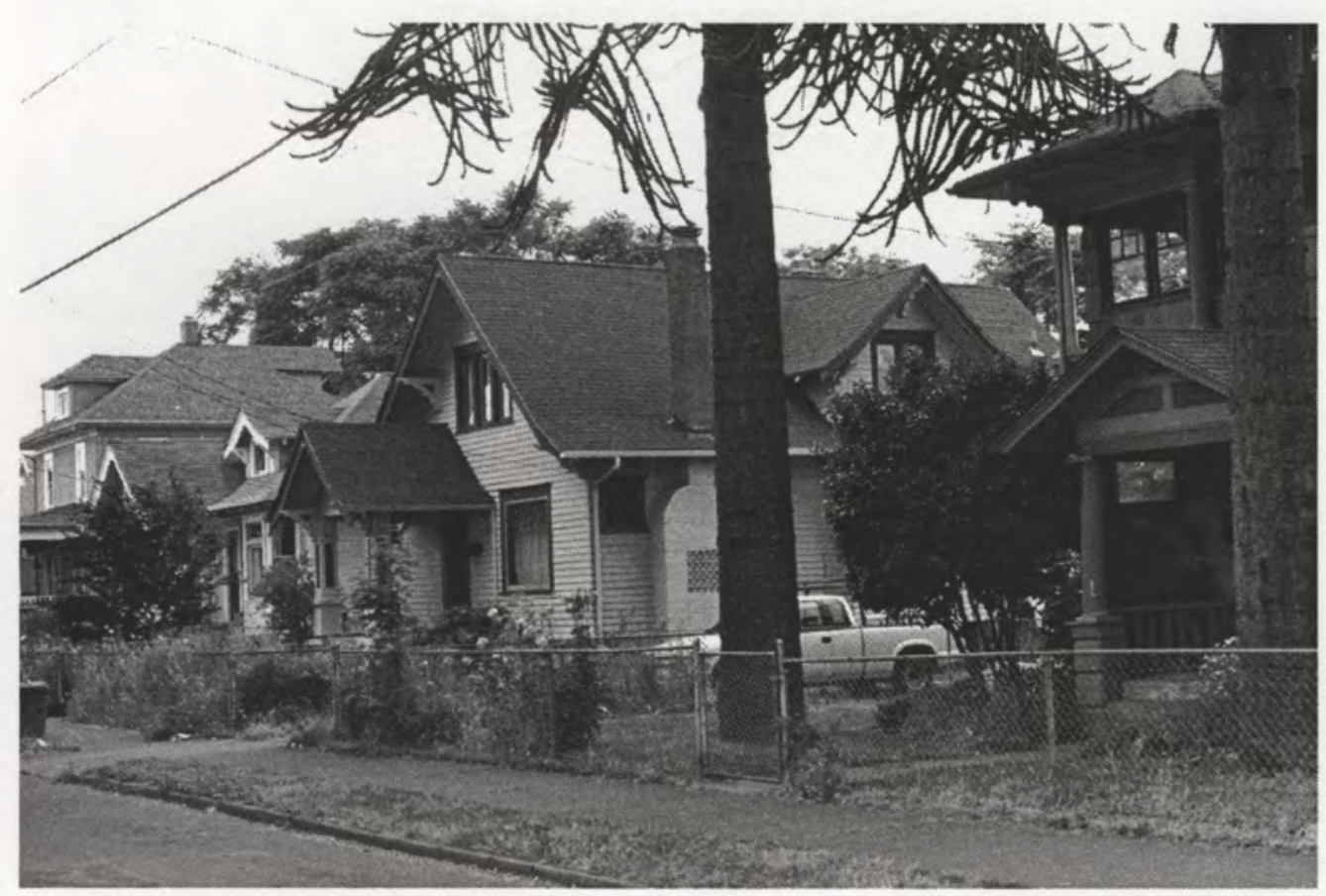

Figure 3.2. Example of Housing Styles Found in Close-In, Older Albina Neighborhoods. 
Residential units farther away from Portland's downtown were newer, post WWII dwellings, resembling more contemporary architectural styles such as Ranch, Cape Cod, and Minimal Traditional (Figure 3.3).

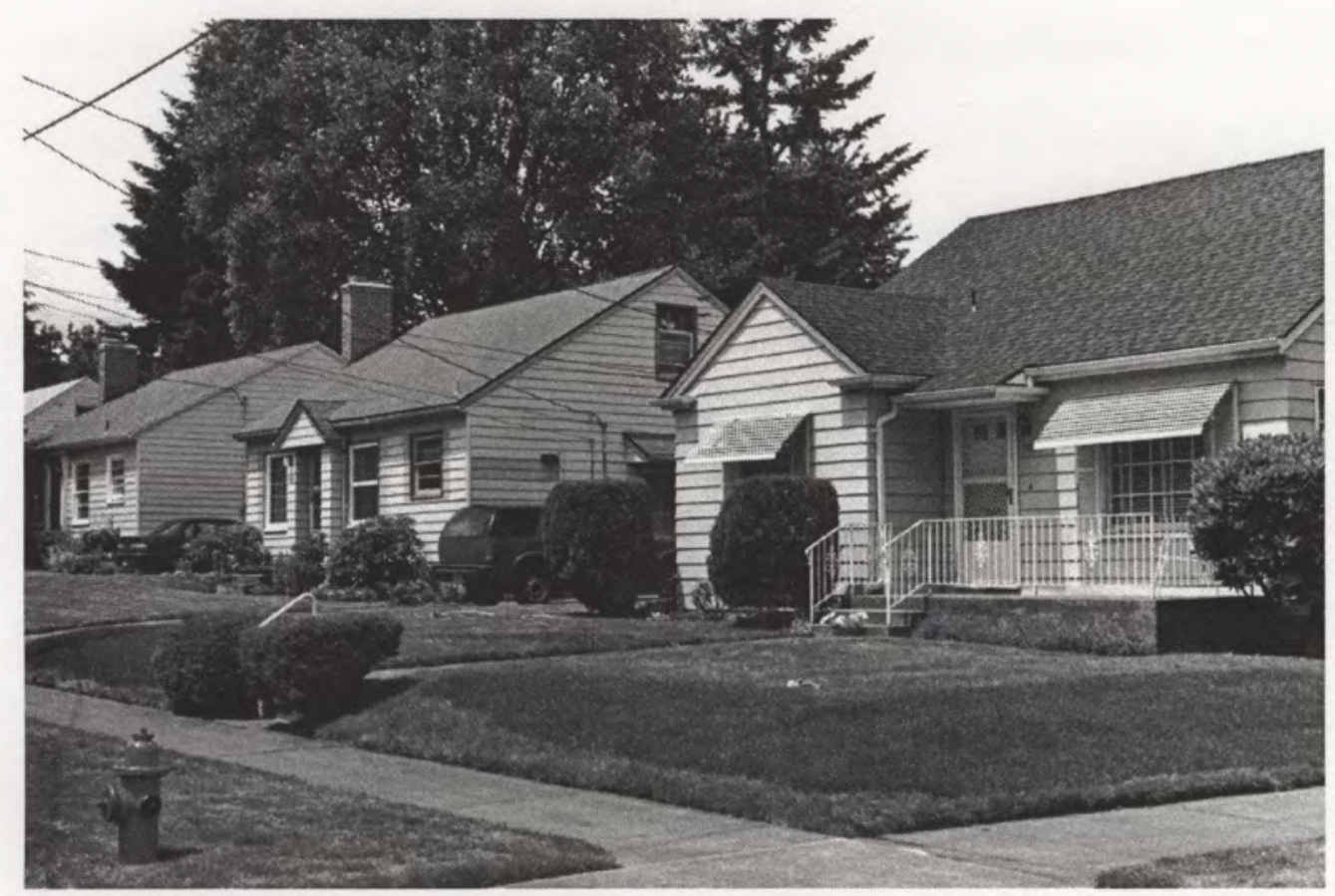

Figure 3.3. Example of Housing Styles Found in Outer, Newer Albina Neighborhoods.

Residential infill development over the past ten years consists of a variety of styles, including one-storied and split level houses characteristic to those found in the suburbs, but most tend to be one and two story detached Neo-Victorian variations, two unit, attached single family dwellings, or rowhousing. 
The condition of the area's housing stock varies considerably. Pockets of both well maintained dwellings and yards as well as neglected dwellings and yards were interspersed throughout Albina. In some areas, the change in condition of housing is drastic - varying from well maintained, finely manicured houses and yards to some of the most dilapidated housing conditions in Portland in a mere block. The nicest housing areas were found in Overlook, the northern end of Humbolt, the western edges of Kenton and Arbor Lodge, and the Vernon and Sabin neighborhoods. Many of the houses in Boise and King appear to have undergone recent renovation. Housing was least well maintained in the northern parts of the Kenton, Piedmont, and Woodlawn neighborhoods. Interspersed throughout the Boise and King neighborhoods are structures in need of repair, but nothing close to the extent found in the northern neighborhoods, where housing dilapidation in some places extends for entire blocks. While there are structures in need of repair, nothing in Albina compares to some of the poor conditions found in larger East Coast cities. There are few boarded up or seriously dilapidated dwellings or vacant lots in the area.

Along residential streets, multifamily units tended to be one to two-story dwellings either of larger, converted single family dwellings or post-WWII apartments. Multifamily units along major arterials appeared to be newer three or four story apartments. 
Commercial strips and centers in the area are diverse, both in type and condition of their development. Main commercial strips include Martin Luther King Jr. Blvd., which extends north/south through the study area; Interstate Avenue, a north/south corridor extending from the southwest corner of the area to Columbia Boulevard; Columbia Boulevard, the northern boundary of primarily residential land use in the study area; Williams Avenue and Vancouver Avenue, one way, north/south streets which extend from Broadway to Killingsworth before turning into residential streets; Broadway, the southern dividing boundary of the study site, and Alberta, Killingsworth, and Lombard, all east/west running arterials with scattered commercial development (Figure 3.4).

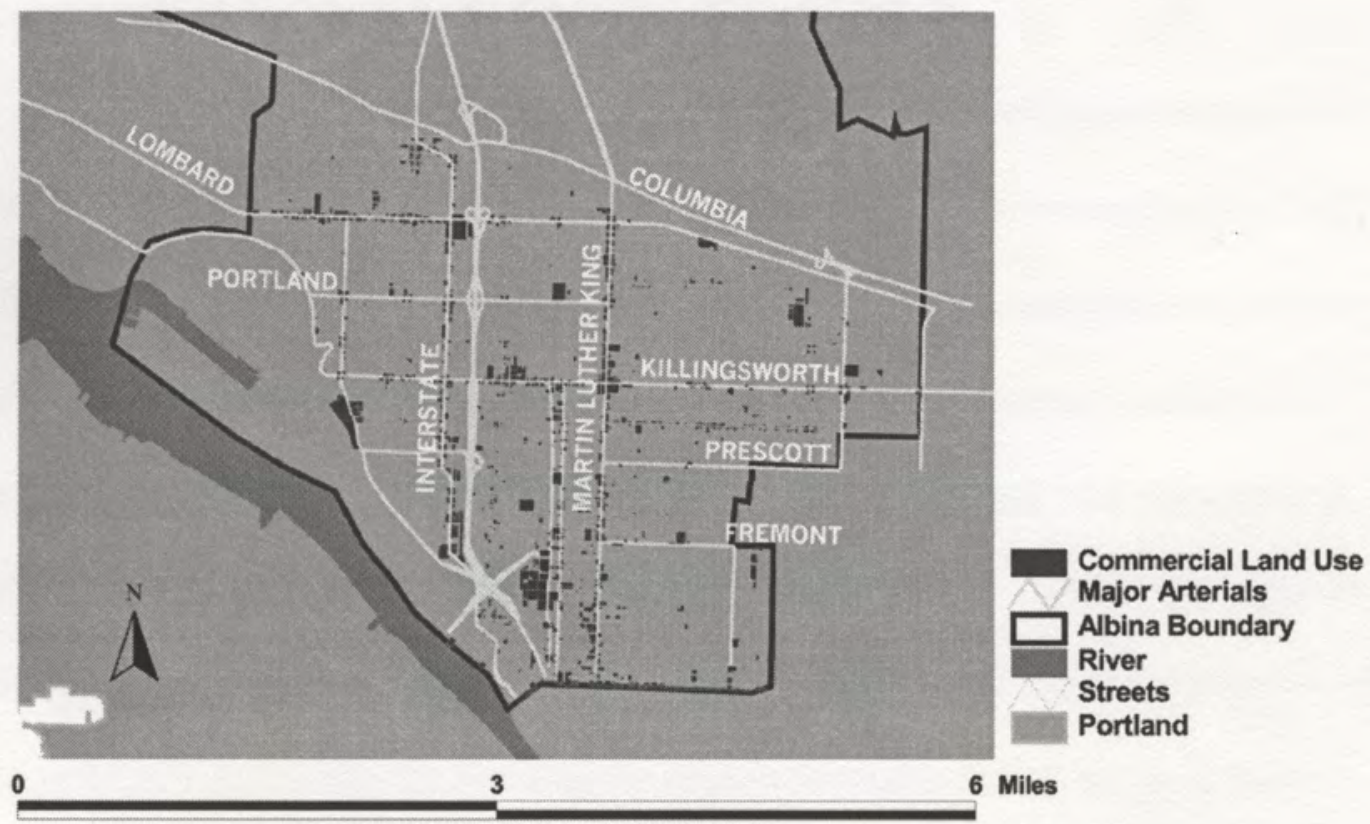

Figure 3.4. Commercial Strips and Centers of the Albina Community, RLIS 2000. 
Commercial development on Columbia, Vancouver, Williams, and Interstate is primarily light industrial businesses. Alberta, Killingsworth, and Lombard have a diverse mix of retail, light industrial, service oriented commercial such as gas stations and auto shops, food establishments, and convenience marts. The physical condition of these streets and commercial dwellings is somewhat run down and in need of upkeep. Considered the corridor of the Albina Community (City of Portland, 1993), Martin Luther King Jr. Blvd. is a mix of retail, food establishments, service oriented commercial, and light industrial uses. Finally, Broadway is comprised of higher end retail shops, food establishments, and service oriented commercial, and appears to be a node of the high end residential Irvington neighborhood.

Neighborhood retail centers exist at the intersections of Broadway and NE 15th, Freemont and NE 15th, Albina and Killingsworth, Denver and Lombard, and Denver and Kilpatrick. These centers are defined by the amount and concentration of surrounding retail as well as by the type of retail. For example, Lombard is a long street of retail and commercial services so the retail center was designated at the intersection of Denver, anchored by two major drug stores with a major grocery store and bank just a few blocks away, while the retail center located at Denver and Kilpatrick is defined by its dense concentration of retail services within a four block radius designation by the neighborhood as the Kenton District. Centers found at Fremont and NE 15th and Broadway and NE 15th, both on the borders of 
the Irvington neighborhood, are high end retail in character, catering not only to the daily needs of the neighborhood residents but to a broader range of consumers with franchise coffee shops, boutiques, and art galleries. The rest of the retail centers appear to fulfill more neighborhood daily needs, with establishments such as meat markets, drug stores, barber shops, and convenience marts. Major grocery stores are located at the intersections of Freemont and NE 15th, Martin Luther King Jr. Blvd. and Ainsworth, and at Lombard and Interstate Avenue.

Overall, the study area is extremely diverse in housing style and size, level of residential upkeep and maintenance, and type of commercial development. While there are many pockets of well kept, maintained properties, the physical condition of commercial strips and nodes, hampered by the near absence of highend retail, indicates this area is home to a high percentage of lower income households.

\section{General Sample Characteristics}

\section{Distribution}

Subsidized houses in the Albina Community were easy to identify. Recent construction was the biggest giveaway. Infill housing in the area appears to be dominated by subsidized houses, with a repetition of housing style. The houses created by Host, NECDC, and Habitat for Humanity consist of only a few different models. NECDCs most common models are what NECDC referred to as the 
Giulietti model (Figure 3.5), a two or three bedroom, two storied, attached house, and the Collins/Andrews model (Figure 3.6), a three bedroom, two story rectangular shaped detached house. Much of the housing created by HOST observed in the sample was attached, or so close together it appeared detached, usually at least three houses, and in some cases block long developments (Figure 3.7). These attached houses are two stories and slightly vary in shape and style (Figure 3.8). Habitat for Humanity houses are most commonly two story, attached two unit houses (Figure 3.9). A recent Habitat for Humanity development in the area, not included in the study because it is still under construction, is a several block development of two story, detached single family homes which exhibit more diversity in style. Also characteristic of all of the new (built after 1990) subsidized houses are porches, a housing trait typical of many of the older architectural styles in the area. 


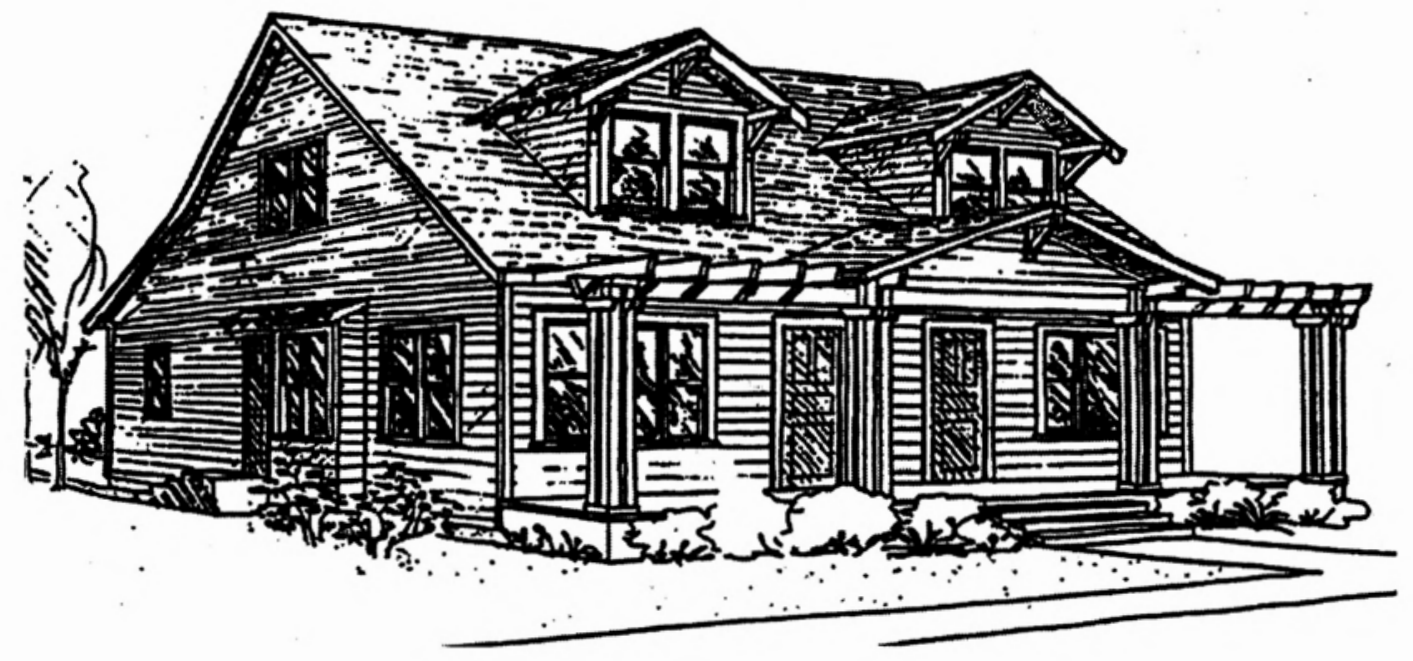

Figure 3.5. Giulietti Model; Example of NECDC Architectural Style.

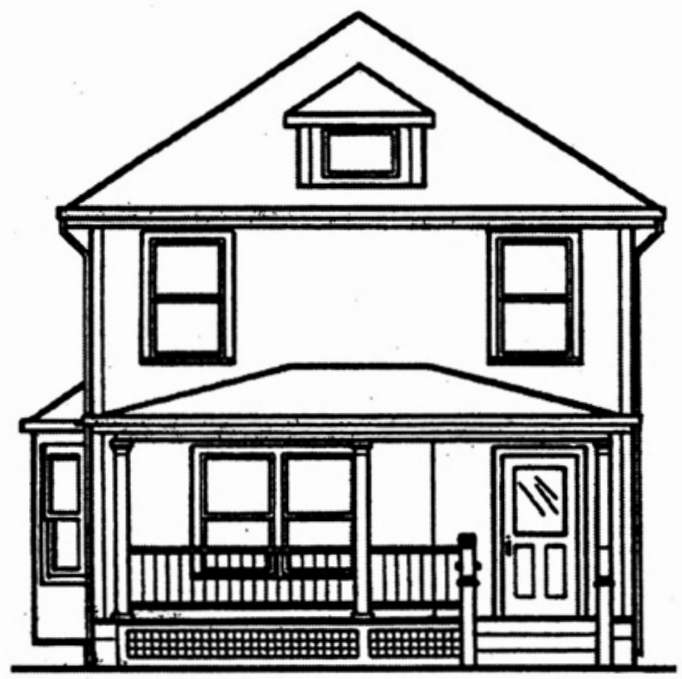

Figure 3.6. Collins/Andrews Model; Example of NECDC Architectural Style. 


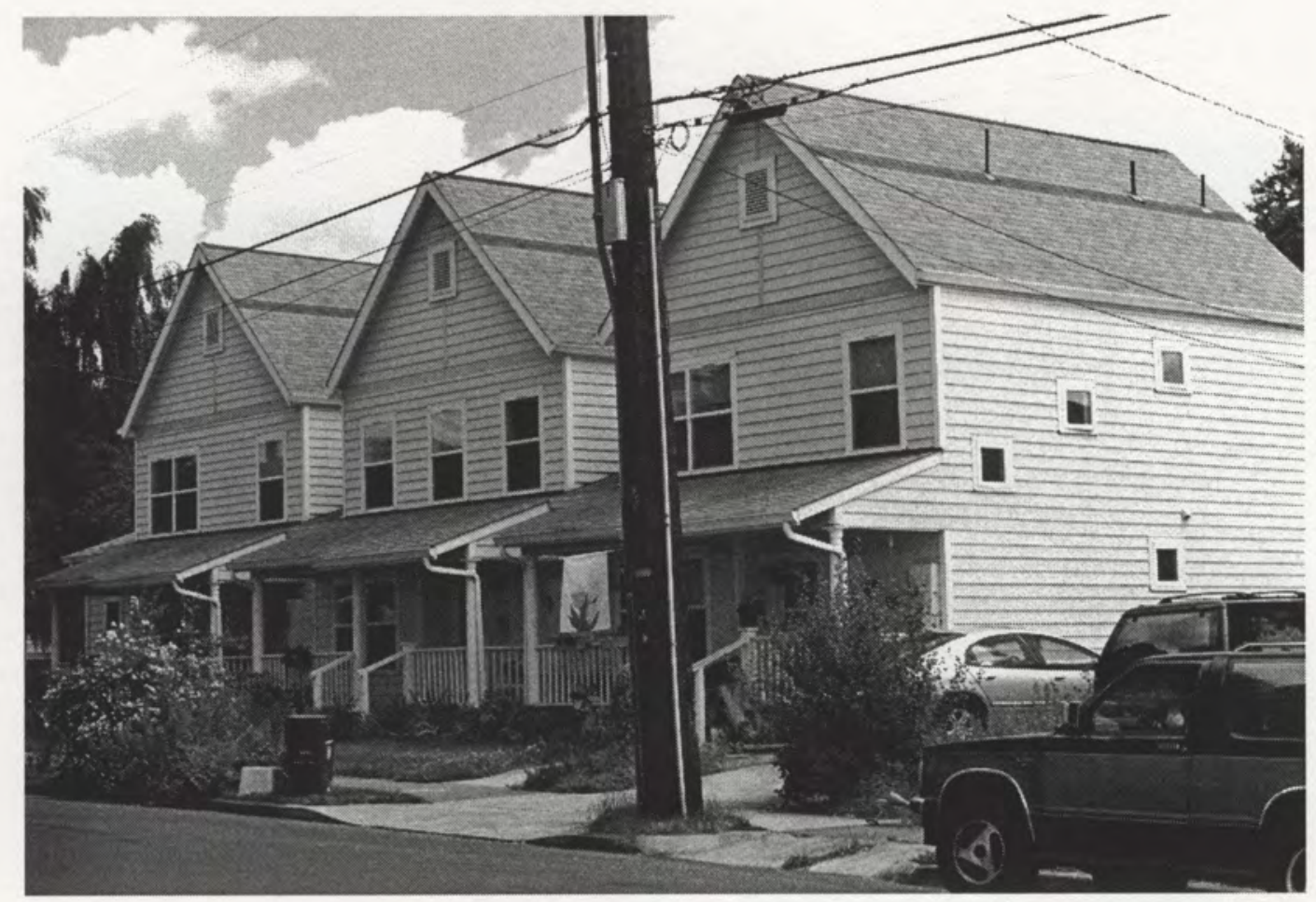

Figure 3.7. Example of HOST Housing; Three unit development.
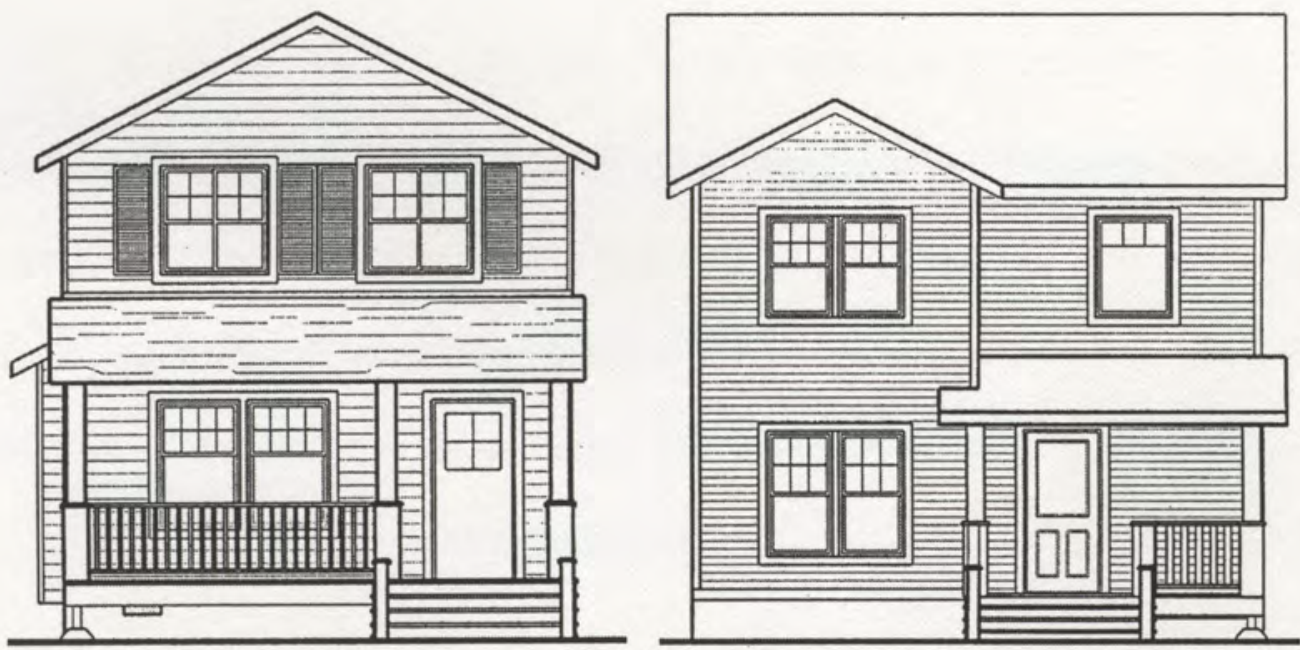

Figure 3.8. Examples of Common HOST Architectural Styles. 


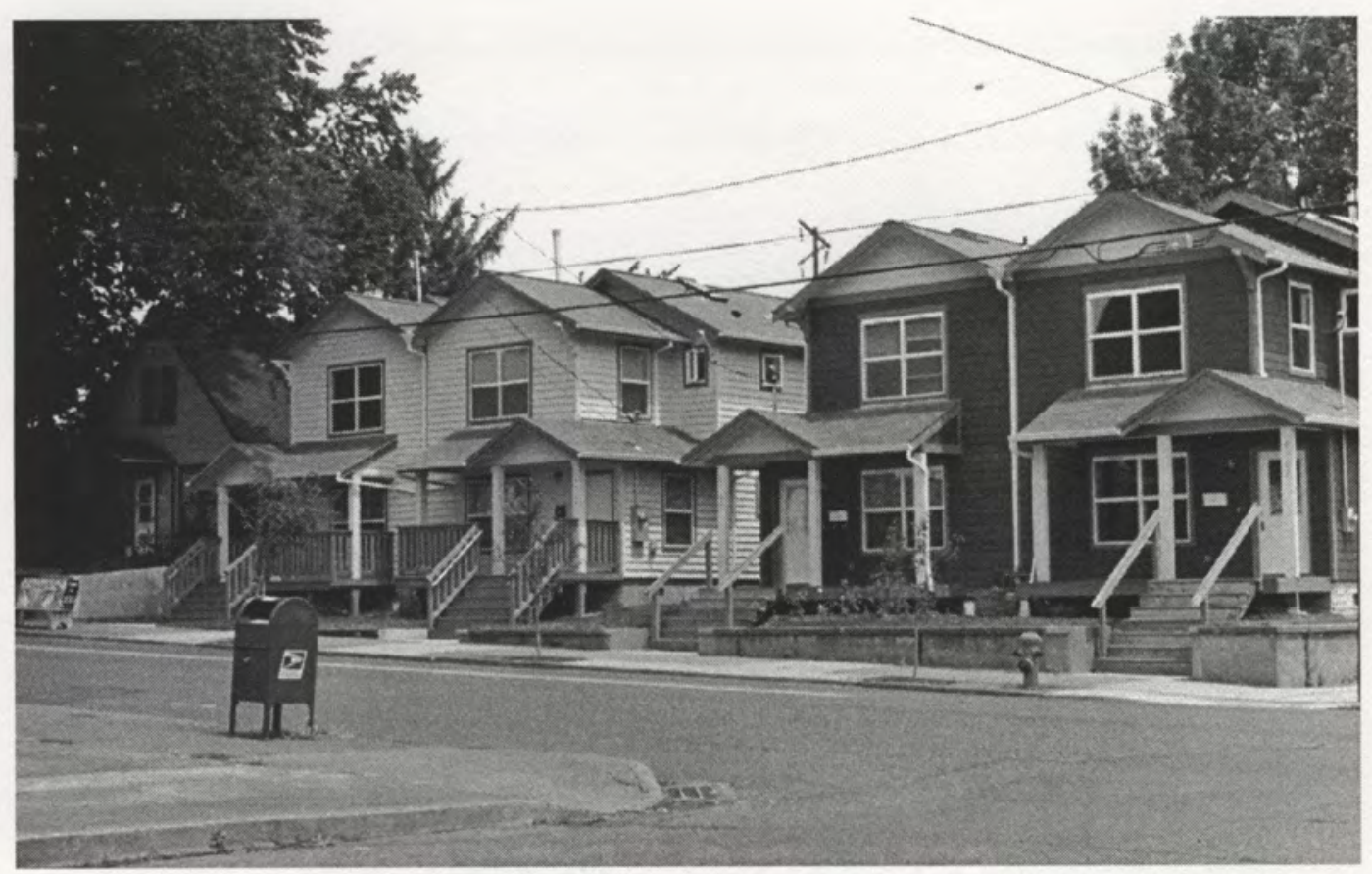

Figure 3.9. Example of Habitat Rowhousing Development.

Market-rate houses varied much more in style than subsidized houses.

Every style in the area was represented in market-rate units from early 1900 styles like Victorian and Bungalow to post WWII styles such as Cape Cod and Ranch. Inherent to the discrepancy found between the two groups in style, is the difference in height. Subsidized houses are mainly two story dwellings, while market-rate houses were one or one-and-a-half stories.

The study sample included 102 units of market-rate housing and 89 units of subsidized housing. While some of the houses were located on main arterials or along frontage roads of Interstate 5, none were in heavily commercialized or 
industrialized areas. Distribution of the two samples reveal subsidized houses are concentrated in a pocket close to Portland's downtown which corresponds to NECDCs service district, the former CDC that developed most of the subsidized houses (Figure 3.10).

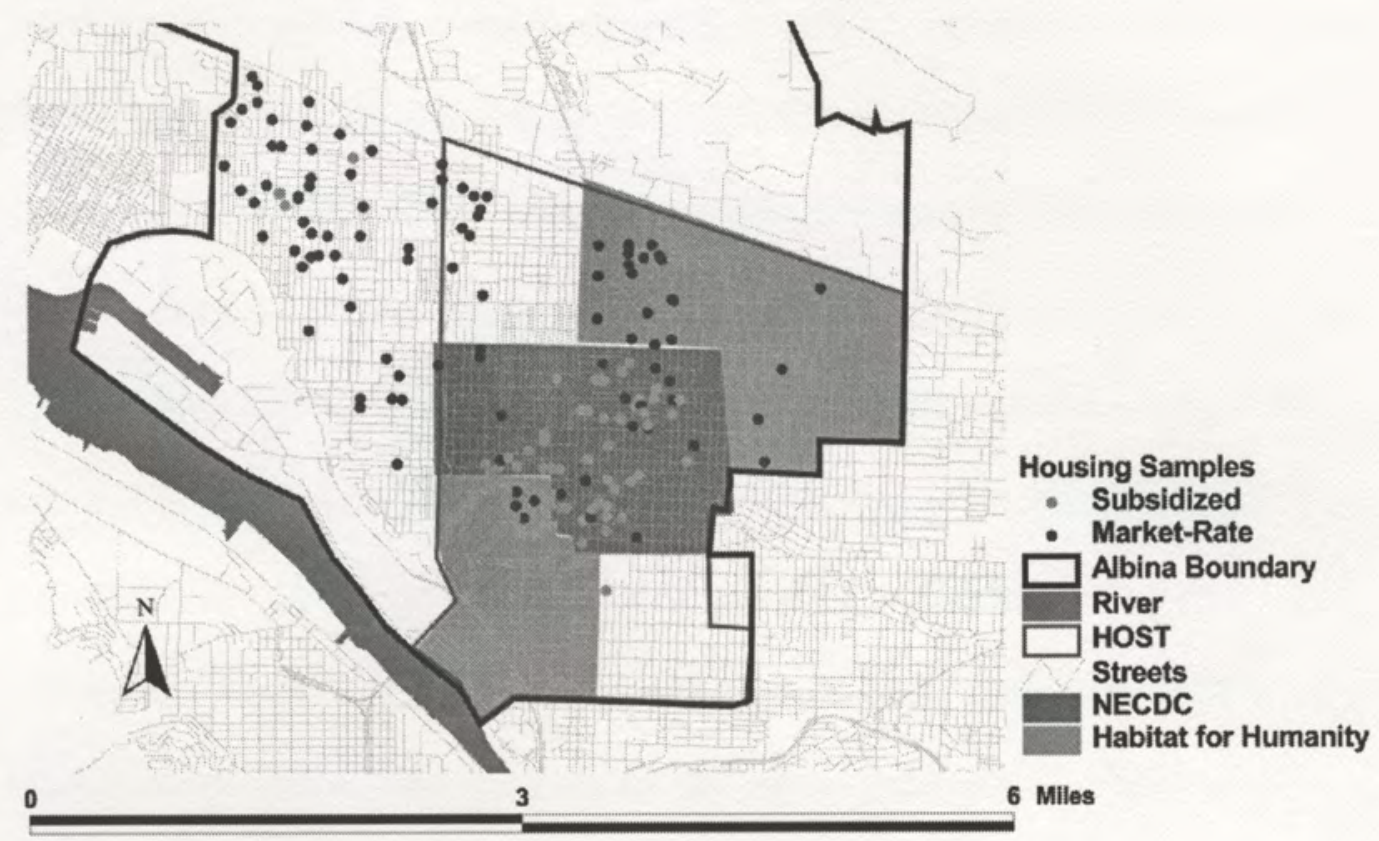

Figure 3.10. Study Sample Distribution and Non-Profit Service Boundaries.

Occurrence of subsidized houses are highest in the Boise (20 units), Humbolt (12 units), and King (40 units) neighborhoods, encompassing $80 \%$ of the total sample.

NECDC, HOST, and Habitat for Humanity boundaries shown here are from data compiled by the Network of Community Development Corporations in 1998. Host has since expanded its boundaries to include all of North and Northeast Portland. As is evident in the map, defined service areas for Habitat for Humanity 
and NECDC overlap those of HOST, specifically in the Boise, King, and Vernon neighborhoods. Also, houses built by Habitat for Humanity and NECDC, while not evident on the map, are present outside of the boundaries defined here, suggesting that they too have expanded their boundaries. While these three non-profit developers are operating in overlapping areas, each creates housing for a different income range. Host services $80-100 \%$ of the median income, NECDC served households at $60-80 \%$ of the median income, and Habitat for Humanity serves households under $50 \%$ of the median income level.

About half of the sampled market-rate houses are within the non-profit developers boundaries. Their distribution is much less densely concentrated than the subsidized houses, extending beyond the area most concentrated with subsidized housing. While the market-rate sample houses can be found throughout Albina's neighborhoods except Eliot and Irvington, these units are in highest concentration in the Kenton (26 units), Woodlawn (18 units), and Arbor Lodge (15 units) neighborhoods, all located along on the outer edges of the Albina Community boundary. The absence of market-rate units in the Eliot and Irvington neighborhoods is attributed to the high cost of owner occupied housing in these areas. Eliot neighborhood is diversely mixed in income distribution, but low to moderate-income housing in this neighborhood is primarily rental.

The shortage of affordable market-rate houses in Albina's inner neighborhoods is a sign that change has occurred in the area. According to the 
1996 American Family Survey, some of Albina's lowest median income, highest unemployment, and poverty rates were observed in these inner neighborhoods (Figure 1.2, Figure 1.3, and Figure 1.4), but the lack of houses under $\$ 125,000$ in this area indicates the trends have changed. The distribution contrast found between the two samples has some positive implications for the work done by nonprofit developers in the area. A large portion of subsidized houses were created between 1994 and 1998, before the close-in area became attractive to higher income households, thereby securing affordable homeownership in upgrading neighborhoods. However, the lack of non-profit developers in the outlying neighborhoods of Albina, where market-rate units are most affordable, suggests the need in these neighborhoods for community development may be growing.

Figure 3.11 shows the distribution of sample units juxtaposed with parcel and building assessment values by square foot for 2000 . The highest concentration of parcels valued under $\$ 70$ per square foot are located in the Boise, King, Humbolt, and Vernon neighborhoods, also the location of the majority of subsidized houses. The correlation seen here is as would be expected. Non-profit developers are developing housing in economically deprived areas. However, as mentioned before, sales data indicates the area may not be as affordable now as it was even two years ago (Oregon Title, 2000). Recent changes in the neighborhoods may not yet be reflected in assessment values for the area. 


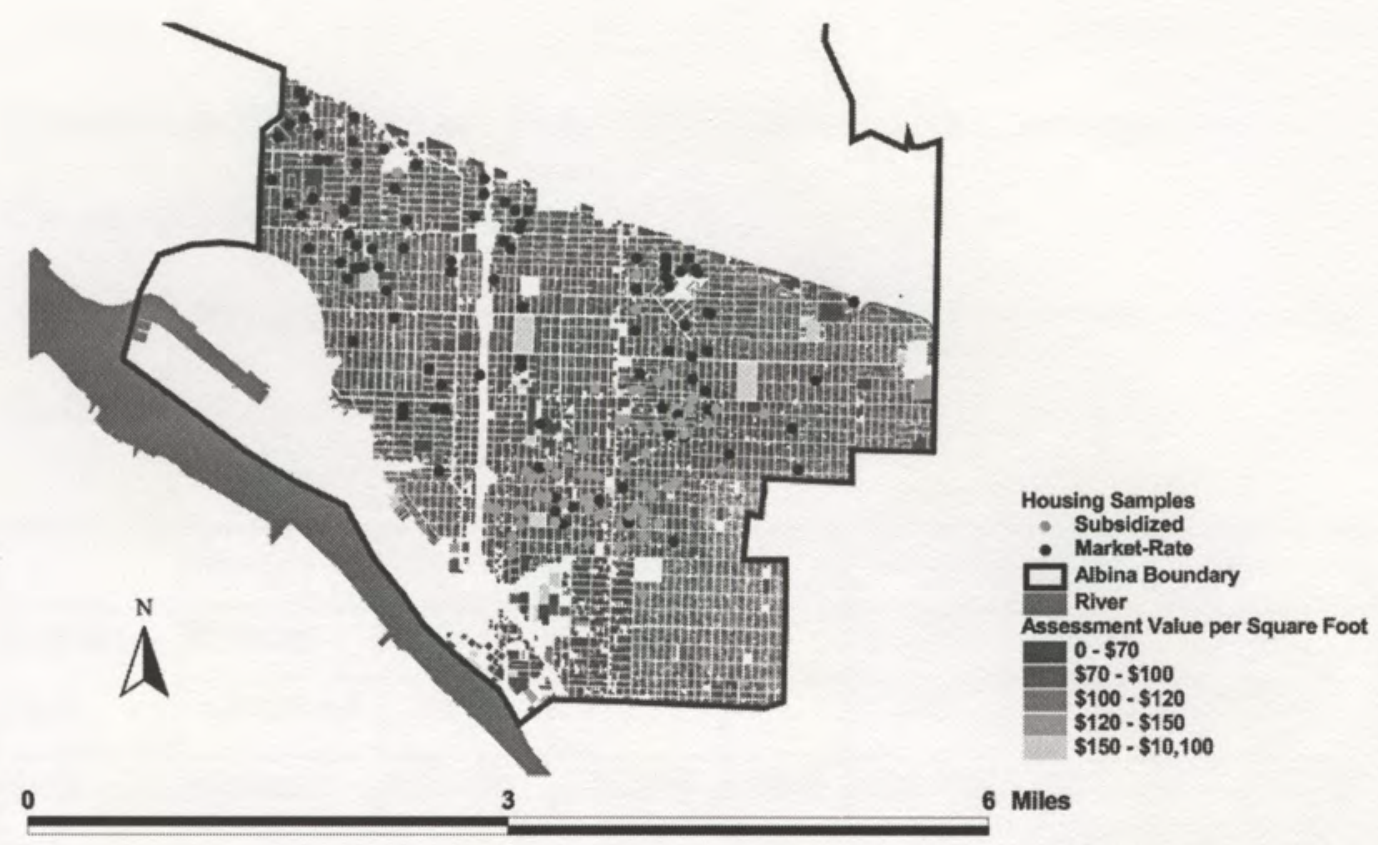

Figure 3.11. Assessment Value by Square Foot of Albina Community Parcels (dwellings included), RLIS, 2000.

Field observations support the notion that these neighborhoods are improving. A changing resident population and increased level of upkeep is evident in the amount of renovation underway.

While the map may not reflect the most current housing conditions, it does explain the strong CDC presence. In the late 1980s and early 1990s, Boise, King, and parts of Humbolt exhibited some of the worst housing and economic conditions in Portland. The presence of more than half of the city's CDCs and non-profit developers operating in North and Northeast Portland is testament that this area was once a prominently impoverished environment. 
Sample Sale Price, Cost per Square Foot, Dwelling Size, and Age

\section{Characteristics}

Houses in the two sample groups varied considerably in size, cost, and age (Table 3.1).

\begin{tabular}{|c|c|c|c|c|c|c|c|}
\hline & Sample & Mean & Median & SD & Variation & Min & Max \\
\hline \multirow{2}{*}{$\begin{array}{l}\text { Square } \\
\text { foot }\end{array}$} & Market & 1080 & 1010 & 340 & 114100 & 530 & 2420 \\
\hline & Subsidized & 1280 & 1270 & 250 & 62100 & 570 & 2570 \\
\hline \multirow{2}{*}{$\begin{array}{l}\text { Sale } \\
\text { Price }\end{array}$} & Market & $\$ 98,100$ & $\$ 101,900$ & 20800 & 432459600 & $\$ 42,100$ & $\$ 125,000$ \\
\hline & Subsidized & $\$ 103,350$ & $\$ 108,800$ & 24930 & 621524730 & $\$ 53,000$ & $\$ 192,000$ \\
\hline \multirow{2}{*}{$\begin{array}{l}\text { Price/ } \\
\text { SQFT }\end{array}$} & Market & $\$ 100$ & $\$ 100$ & 32 & 1040 & $\$ 40$ & $\$ 180$ \\
\hline & Subsidized & $\$ 82$ & $\$ 87$ & 18 & 316 & $\$ 44$ & $\$ 114$ \\
\hline \multirow{2}{*}{$\begin{array}{l}\text { Year } \\
\text { Built }\end{array}$} & Market & 1930 & 1920 & 21 & 461 & 1890 & 1995 \\
\hline & Subsidized & 1980 & 1995 & 34 & 1150 & 1890 & 2000 \\
\hline
\end{tabular}

Table 3.1. Total Square Foot, Sale Price, Cost per Square Foot, and Year Built for Sampled Market-Rate and Subsidized Houses.

One of the inherent differences found between the subsidized and market-rate housing styles was the number of stories the houses had. With subsidized houses up to a full story taller than the market-rate houses, size differences are expected. Most of the subsidized sampled houses (79\%) were between 1,000 and 1,500 square feet in size. Almost half of the market-rate units were under 1,000 square 
feet. Of these smaller houses, half are located in the Kenton neighborhood, where housing is a mixture of smaller, one and one-and-a-half story Cape Cod, Arts and Crafts, Minimal Traditional styles, and one story Ranch style housing. Mean figures for total square footage show subsidized houses are on average $200 \mathrm{sqft}$ larger than sampled market-rate houses. The sampled data showed overall sales prices were on average about $\$ 5000$ more per house in subsidized housing $(\$ 103,350)$ than in market-rate $(\$ 98,000)$. Price per square foot figures are necessary to determine whether non-profit developers are providing larger houses at a lower price than the market is able to do.

Not only are the subsidized houses larger on average, they are also substantially cheaper per square foot. Sampled market-rate houses are almost $20 \%$ more expensive per square foot than the subsidized houses. Of the sampled subsidized houses, $80 \%$ cost between $\$ 40$ and $\$ 100$ per square foot, while $70 \%$ of the market-rate sample cost over $\$ 80$ per sqft. These results suggest that subsidized houses are making a sizable difference in the cost of housing for low to moderateincome homebuyers in Albina by providing larger, more affordable houses than the market.

Field observations revealed the sampled subsidized houses were much newer than the market-rate sample. Renovations of older structures constituted $20 \%$ of the sampled subsidized houses; the rest of the subsidized housing was built after 1990. Three of the renovated houses were built after 1950; the rest were built 
between 1890 and 1935 . Of the market-rate houses sampled, $70 \%$ were built before 1930. Most of the remaining $30 \%$ were found in the Kenton and Woodlawn neighborhoods and ranged in year built from 1950 to 1980 . Median ages exhibit a 75 year difference between the two sample groups. With a majority of sampled subsidized houses at least 60 years newer than the bulk of the market-rate sample, structural quality of these houses should far surpass the market-rate units, which have become affordable through filtering.

\section{Quality Indicators}

\section{Exterior Physical Quality}

Based on field survey results, little variation exists in exterior physical quality between the two groups of housing (Table 3.2). None of the houses sampled were in poor condition. Most houses in both groups were between a 1 (sound) and a 2 (needing minor repair) in quality. Only three houses, all of which were subsidized renovation units, received quality scores below 2 . 


\begin{tabular}{|c|c|c|c|c|c|c|c|}
\hline Neighborhood & Sample & $\mathbf{N}$ & Mean & Min & Max & SD & Variation \\
\hline Arbor Lodge & Market & 15 & 1.4 & 1.0 & 2.0 & 0.3 & 0.1 \\
\hline \multirow[t]{2}{*}{ Boise } & Market & 4 & 1.4 & 1.0 & $\overline{1.7}$ & 0.3 & 0.1 \\
\hline & Subsidized & 20 & 1.4 & 1.0 & 2.1 & 0.3 & 0.1 \\
\hline \multirow[t]{2}{*}{ Concordia } & Market & 4 & 1.4 & 1.0 & 1.9 & 0.4 & 0.1 \\
\hline & Subsidized & 1 & 1.0 & 1.0 & 1.0 & 0.0 & 0.0 \\
\hline \multirow[t]{2}{*}{ Humbolt } & Market & 4 & 1.3 & 1.0 & $\overline{1.6}$ & 0.3 & 0.1 \\
\hline & Subsidized & 12 & 1.6 & 1.0 & 2.4 & 0.4 & 0.2 \\
\hline Irvington & Subsidized & 1 & 1.1 & 1.1 & 1.1 & 0.0 & 0.0 \\
\hline \multirow[t]{2}{*}{ Kenton } & Market & 26 & 1.5 & 1.0 & 2.0 & 0.3 & 0.1 \\
\hline & Subsidized & 4 & 1.2 & 1.0 & 1.6 & 0.3 & 0.1 \\
\hline \multirow[t]{2}{*}{ King } & Market & 9 & 1.4 & 1.0 & 1.9 & 0.3 & 0.1 \\
\hline & Subsidized & 40 & 1.4 & 1.0 & 2.3 & 0.3 & 0.1 \\
\hline Overlook & Market & 8 & 1.3 & 1.1 & 1.4 & 0.1 & 0.0 \\
\hline Piedmont & Market & 9 & 1.4 & 1.1 & 2.0 & 0.2 & $\overline{0.1}$ \\
\hline \multirow[t]{2}{*}{ Sabin } & Market & 1 & 1.6 & 1.6 & 1.6 & 0.0 & 0.0 \\
\hline & Subsidized & 1 & 1.0 & 1.0 & 1.0 & 0.0 & 0.0 \\
\hline \multirow[t]{2}{*}{ Vernon } & Market & 4 & 1.4 & 1.1 & 1.7 & 0.3 & 0.1 \\
\hline & Subsidized & 8 & 1.3 & 1.1 & 1.7 & 0.2 & 0.0 \\
\hline \multirow[t]{2}{*}{ Woodlawn } & Market & 18 & 1.4 & 1.0 & 2.0 & 0.3 & 0.1 \\
\hline & Subsidized & 2 & 1.2 & 1.0 & 1.3 & 0.2 & 0.0 \\
\hline
\end{tabular}

Table 3.2. Exterior Physical Quality Ratings for Sampled Market-Rate and Subsidized Houses by Neighborhood. 
Most of the subsidized housing was in sound condition, primarily because it was new. Two-thirds of these houses received quality scores between 1 and 1.5 (Figure 3.12).
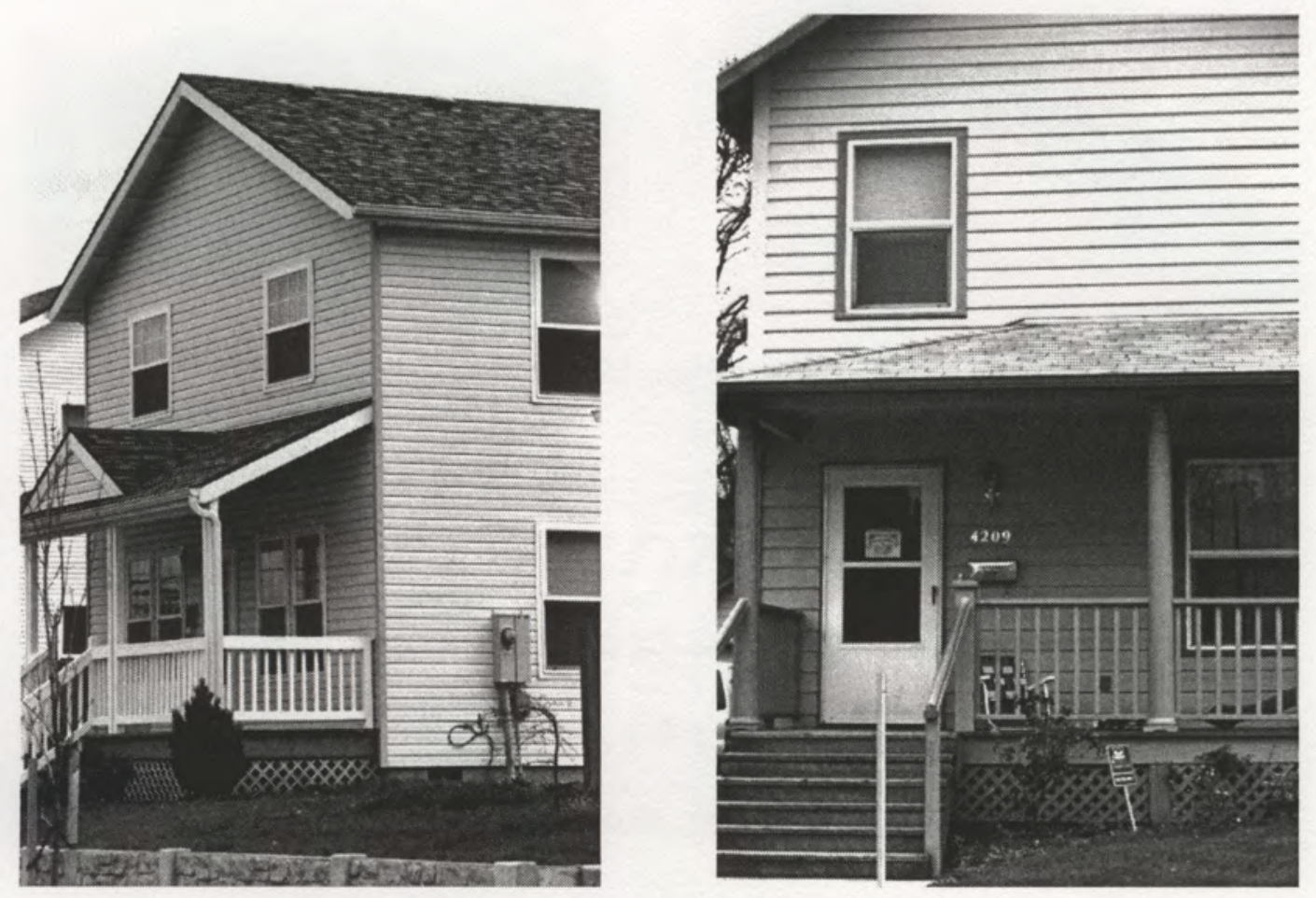

Figure 3.12. Examples of Sampled Subsidized Houses with 1-1.5 Exterior Ratings.

Of the seven categories - roof, eaves, windows, walls, doors, porch, and yard - most frequently noted minor repair needs for subsidized houses were of the eaves, windows, and porches. The wooden eaves and porches of some of the older 
houses, built between 1992 and 1996 needed minor repairs because they had split, the paint was peeling, or they were starting to mold (Figure 3.13).
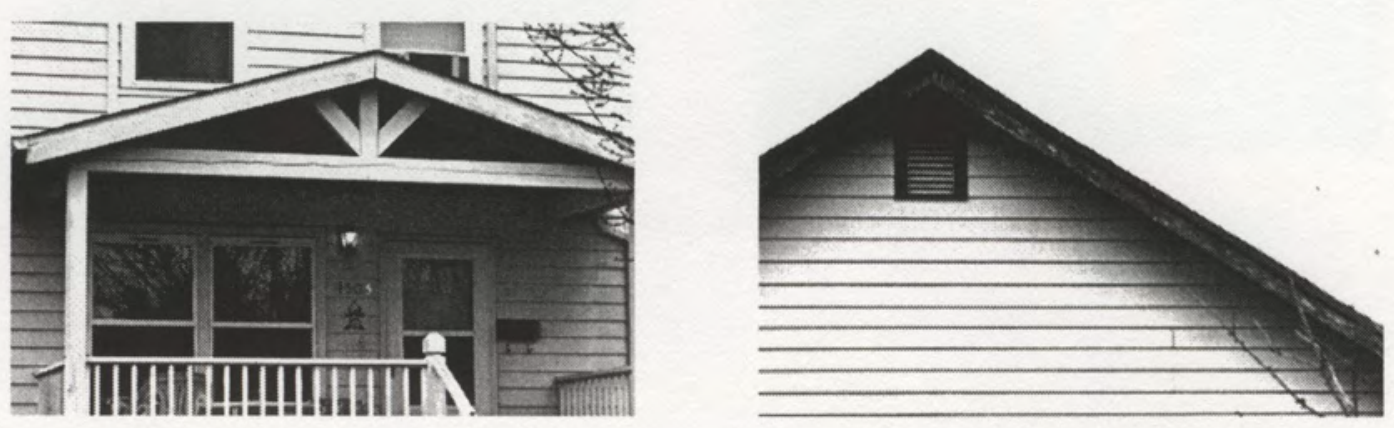

Figure 3.13. Examples of Common Minor Repair Needs; Split Porch Eave and Peeling Eave.

Torn screening hung from some of the windows on the houses built between 1992 and 1996. Also, the window framing, either wood or plastic, was often damaged or in need of paint. Most of the walls, roofs, and doors were in excellent condition. NECDC and HOST used plastic siding on most units, a main factor in consistently high wall quality scores. Yards varied greatly; generally, the newer the house, the better the yard upkeep.

Market-rate houses were in surprisingly sound condition as well (Figure $3.14)$. 

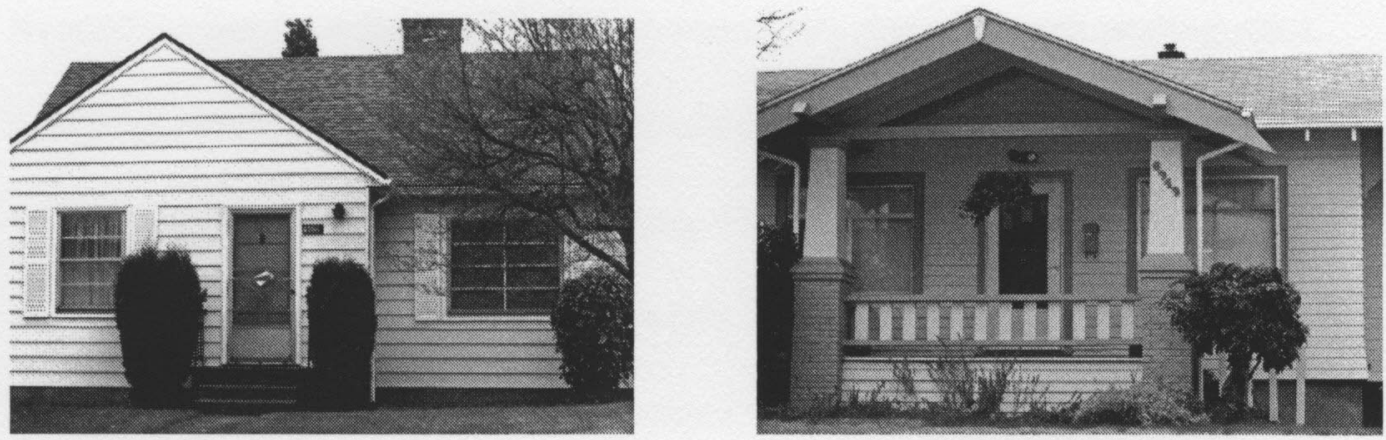

Figure 3.14. Examples of Sampled Market-Rate Houses with 1-1.5 Exterior Ratings.

Seventy percent of the market-rate sample was rated between 1 and 1.5 in exterior quality. Houses displayed an increased need for repairs in outer neighborhoods. Elements of market-rate housing most frequently in need of repair included roofs, walls, windows, and yards. Some roofs had minor to extensive mold growth. Of the houses that needed exterior wall repair, most needed to be repainted (Figure $3.15)$.
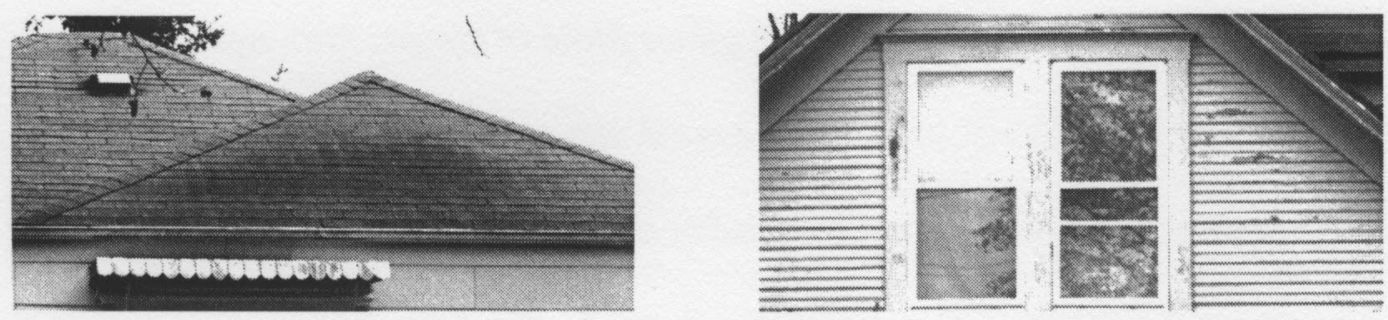

Figure 3.15. Examples of Common Minor Repair Needs; Moldy Roof and Peeling Paint. 
Needed repairs for windows were most commonly due to rot and peeling paint. Common characteristics of neglected yards included overgrown or unattended vegetation, decayed fencing and retaining walls, and presence of litter, appliances, and vehicles. Some of the older market-rate houses were under renovation, evident from exterior work in progress, or appeared to have recently been renovated.

The physical ratings for both sample groups were extremely good. Little difference existed between the two groups in overall exterior quality ratings. However, differences were observed among different parts of the house. Housing elements showing signs of minor wear in the newer subsidized houses included eaves, porches, and windows, reflecting the use of low-grade materials. Marketrate houses on the other hand, showed typical signs of wear with age; molding roofs, peeling paint on exterior walls and windows, and rotting windows.

\section{Block Rating}

In most Albina neighborhoods, little difference existed between the two sampled groups with respect to block rating (Table 3.3). In Concordia and Kenton, neighborhood ratings for market-rate houses were about one full ranking lower than subsidized housing blocks. In Vernon, subsidized housing blocks were almost one ranking below market-rate units. Forty-four percent of the subsidized sample and $38 \%$ of the market-rate sample received block ratings between 1 (very good) and 2 (good). 


\begin{tabular}{|c|c|c|c|c|c|c|c|}
\hline Neighborhood & Sample & $\overline{\mathbf{N}}$ & Mean & Min & $\operatorname{Max}$ & SD & Variation \\
\hline Arbor Lodge & Market & 15 & 2.7 & 1 & 4 & 0.7 & $\overline{0.5}$ \\
\hline \multirow[t]{2}{*}{ Boise } & Market & 4 & 2.5 & 2 & 3 & 0.6 & $\overline{0.3}$ \\
\hline & Subsidized & 20 & 2.1 & 2 & 3 & 0.3 & 0.1 \\
\hline \multirow[t]{2}{*}{ Concordia } & Market & 4 & 2.0 & 1 & 3 & 0.8 & 0.7 \\
\hline & Subsidized & 1 & 1.0 & 1 & 1 & 0.0 & 0.0 \\
\hline \multirow[t]{2}{*}{ Humbolt } & Market & 4 & 2.8 & 2 & 3 & 0.5 & 0.3 \\
\hline & Subsidized & 12 & 2.8 & 2 & 3 & 0.4 & 0.2 \\
\hline Irvington & Subsidized & 1 & 1.0 & 1 & 1 & 0.0 & 0.0 \\
\hline \multirow[t]{2}{*}{ Kenton } & Market & 26 & 2.7 & 1 & 4 & 0.8 & 0.6 \\
\hline & Subsidized & 4 & 1.8 & 1 & 2 & 0.5 & 0.3 \\
\hline \multirow[t]{2}{*}{ King } & Market & 9 & 2.9 & 2 & 3 & 0.3 & 0.1 \\
\hline & Subsidized & 40 & 2.7 & 2 & 3 & 0.5 & 0.2 \\
\hline Overlook & Market & 8 & 1.9 & 1 & 3 & 0.8 & 0.7 \\
\hline Piedmont & Market & 9 & 2.7 & 2 & 3 & 0.5 & 0.3 \\
\hline \multirow[t]{2}{*}{ Sabin } & Market & 1 & 2.0 & 2 & 2 & 0.0 & 0.0 \\
\hline & Subsidized & 1 & 2.0 & 2 & 2 & 0.0 & 0.0 \\
\hline \multirow[t]{2}{*}{ Vernon } & Market & 4 & 2.3 & 2 & 3 & 0.5 & 0.3 \\
\hline & Subsidized & 8 & 3.0 & 3 & 3 & 0.0 & 0.0 \\
\hline \multirow[t]{2}{*}{ Woodlawn } & Market & 18 & 2.7 & 2 & 3 & 0.5 & 0.2 \\
\hline & Subsidized & 2 & 2.5 & 2 & 3 & 0.7 & 0.5 \\
\hline
\end{tabular}

Table 3.3. Block Rating for Sampled Market-Rate and Subsidized Houses by

Neighborhood. 
The majority of units for both samples ( $96 \%$ CDC, $89 \%$ market-rate) scored between 2 (good) and 3 (average) (Figure 3.16).

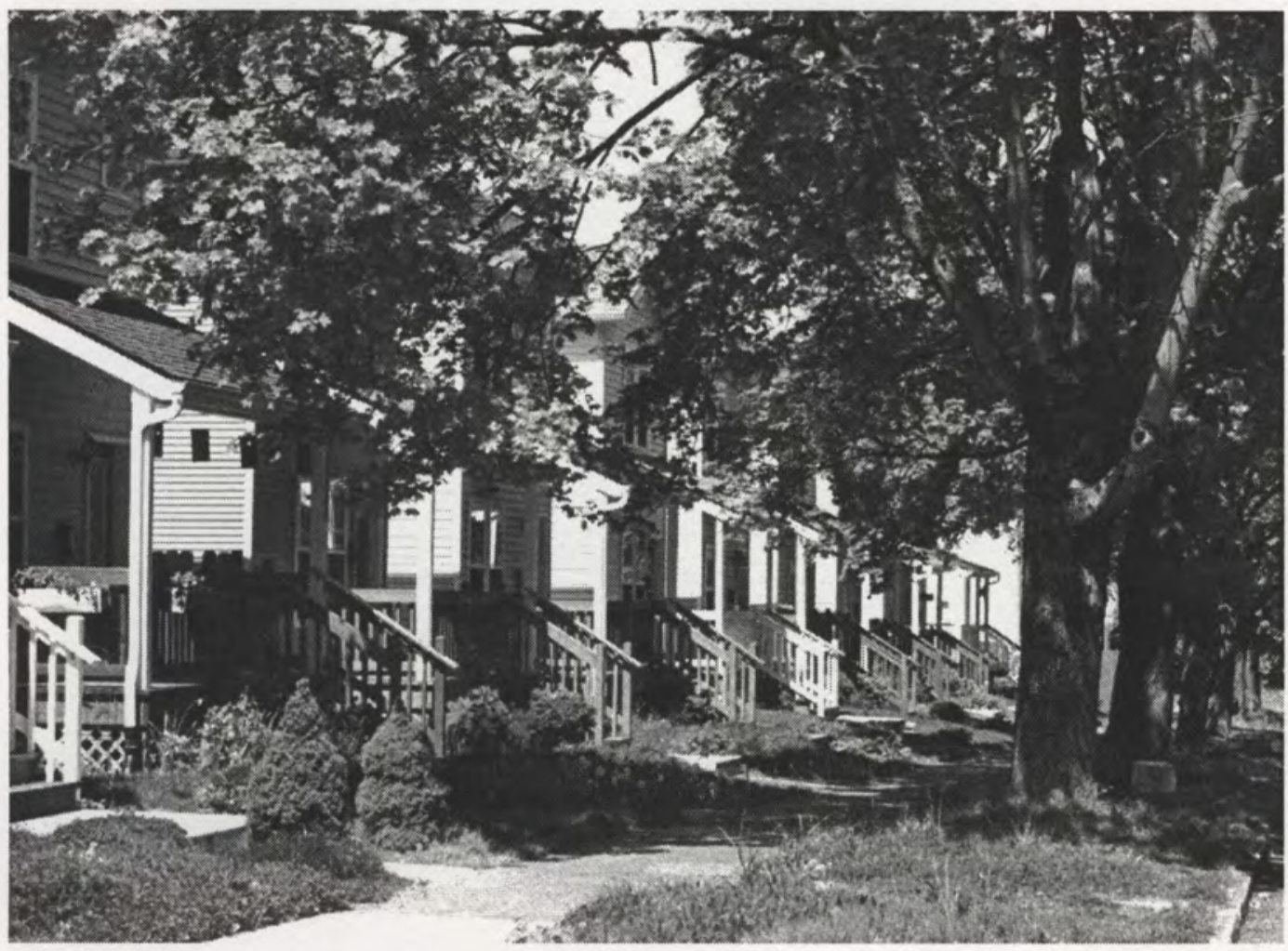

Figure 3.16. Example of Sampled Unit Blocks with Very Good to Good Ratings.

Block elements contributing to a high rating include healthy and abundant street vegetation, absence of litter, and well maintained yards and units.

Lowered block ratings for the subsidized sample were most frequently due to a high block proportion of run-down housing, high presence of litter, and strong 
presence of unkempt yards. For the market-rate sample, lowered block ratings were attributed to unimproved roads, location on a major arterial or overlooking Interstate 5, high presence of unkempt yards, high block proportion of run-down housing, and sparse or dead vegetative cover (Figure 3.17).

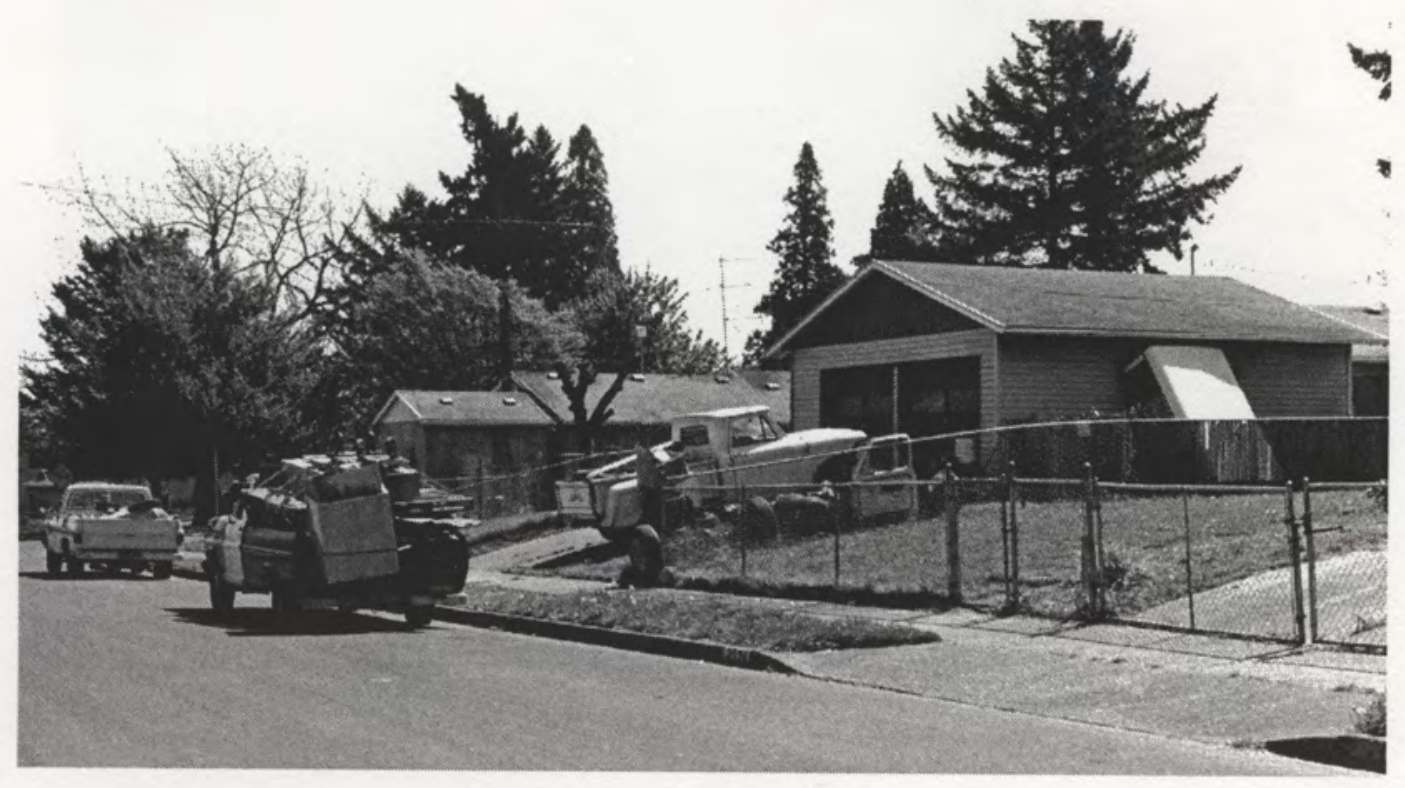

Figure 3.17. Example of Sampled Unit Blocks with Poor Ratings. Block elements contributing to a low rating include a dead tree standing in the background, parts of a vehicle litter a residents lawn, and over all run down state of units on the block.

\section{Neighborhood Amenities}

Area amenities such as retail centers, grocery stores, bus stops, parks, and schools, were all located within about a mile of each sampled house (Figure 3.18). 


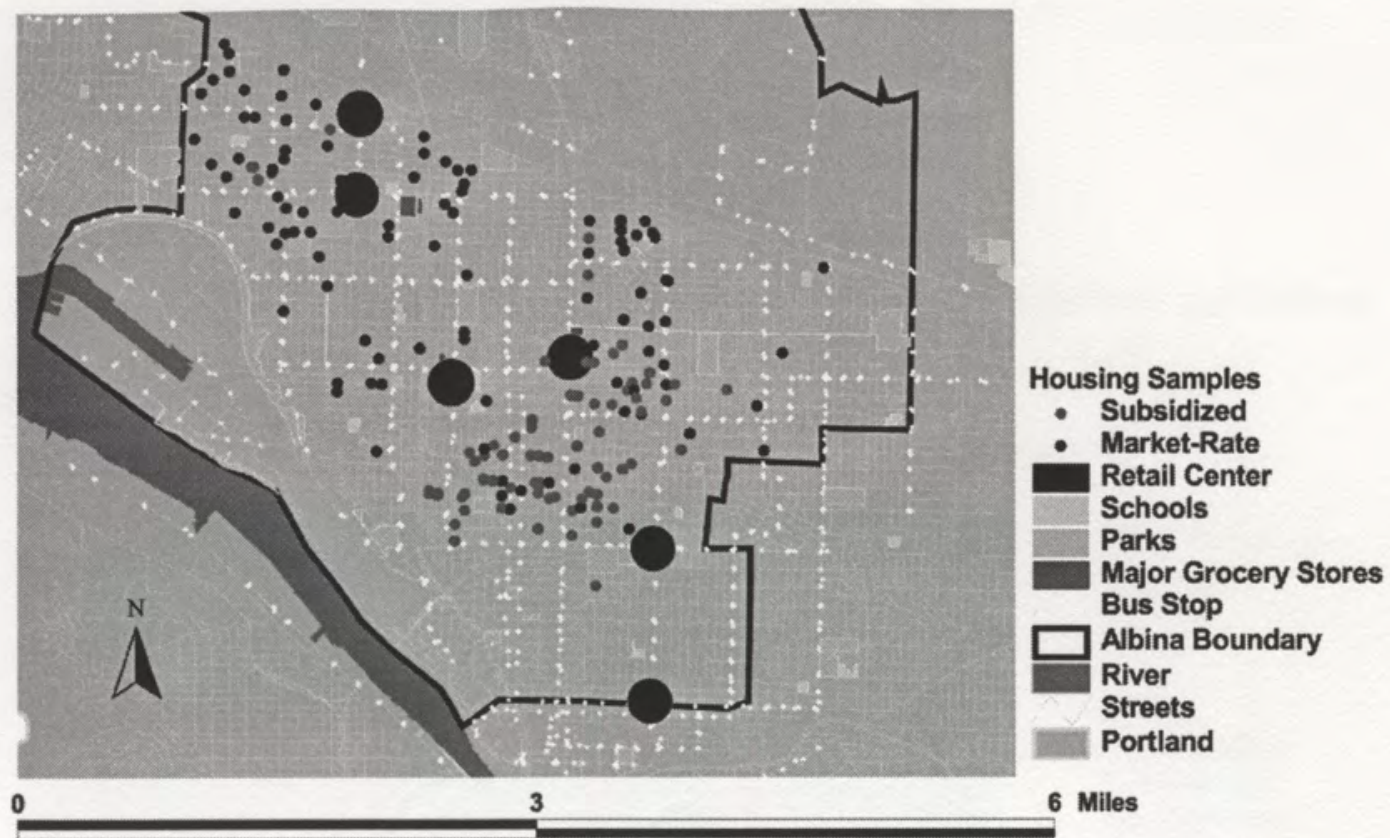

Figure 3.18. Market-Rate and Subsidized Sampled Housing and Proximity to Neighborhood Amenities.

Between samples, there was some difference in the proportion of houses within maximum walking distance (1/4 mile) to schools, but otherwise each sample showed very little difference in proximity to amenities. Of the subsidized houses sampled, $7 \%$ were within maximum walking distance $(.25$ miles) to schools, while $26 \%$ of the market-rate houses were within a quarter mile. Most frequently found within walking distance of sampled houses were bus stops (subsidized $97 \%$, market-rate $100 \%$ ) and parks (subsidized $97 \%$, market-rate $100 \%$ ). Few of the 
sampled houses were within walking distance to retail (subsidized 14\%, marketrate $11 \%$ ) or grocery centers (subsidized $11 \%$, market-rate $14 \%$ ).

\section{Area Crime Rates}

Crimes committed were highest in the Eliot neighborhood, a neighborhood lacking sampled houses (Figure 3.19).

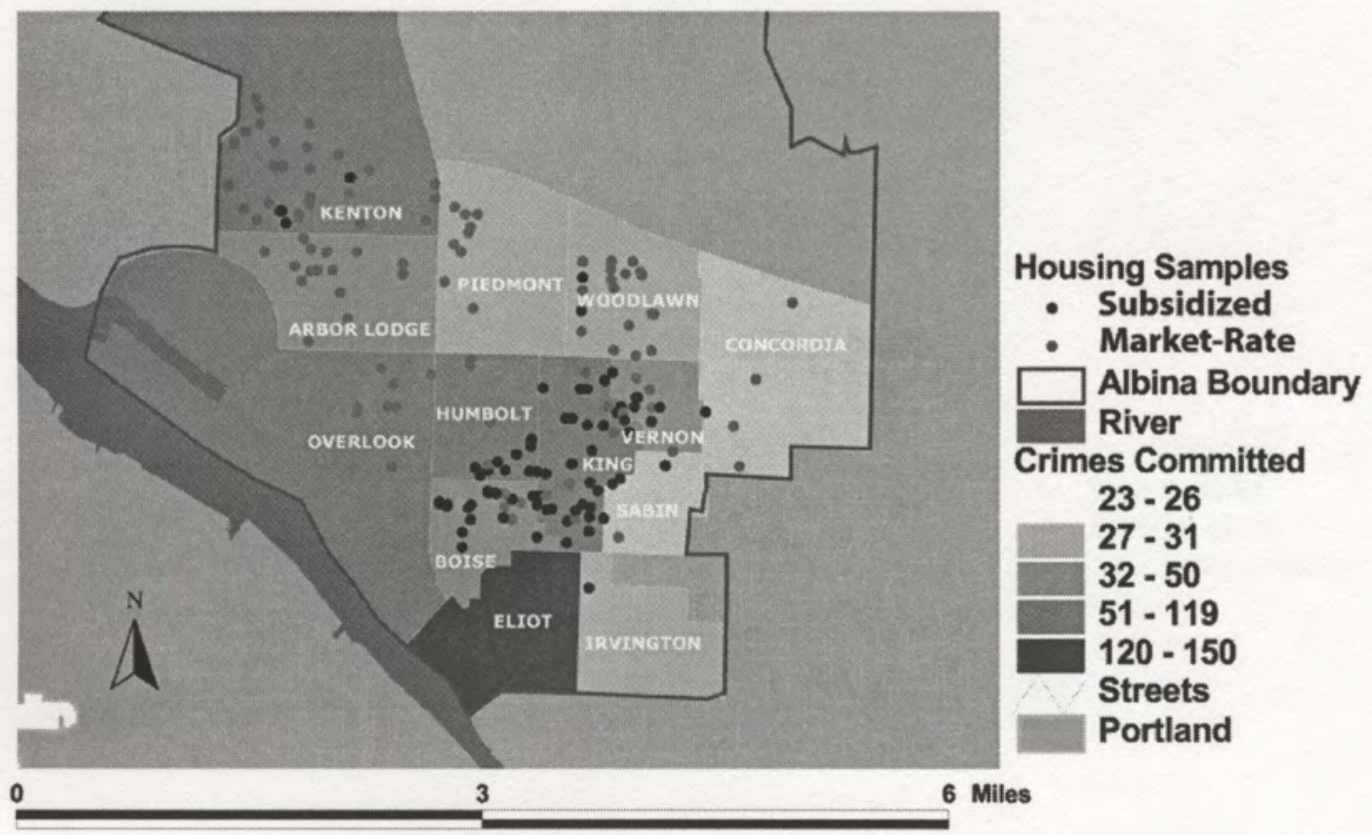

Figure 3.19. Neighborhood Crime Rates and Market-Rate and Subsidized Sampled Housing Distribution.

Neighborhoods experiencing the next highest number crimes - Kenton, Overlook, Humbolt, and King - contained 55\% of the sampled subsidized houses and $46 \%$ of 
the market-rate houses. Little difference exists between the two groups in proportion of houses located in neighborhoods in relation to incidence of crime.

\section{Proximity to Portland's CBD}

Substantial differences existed between the two groups with relation to proximity to Portland's CBD (Figure 3.20).

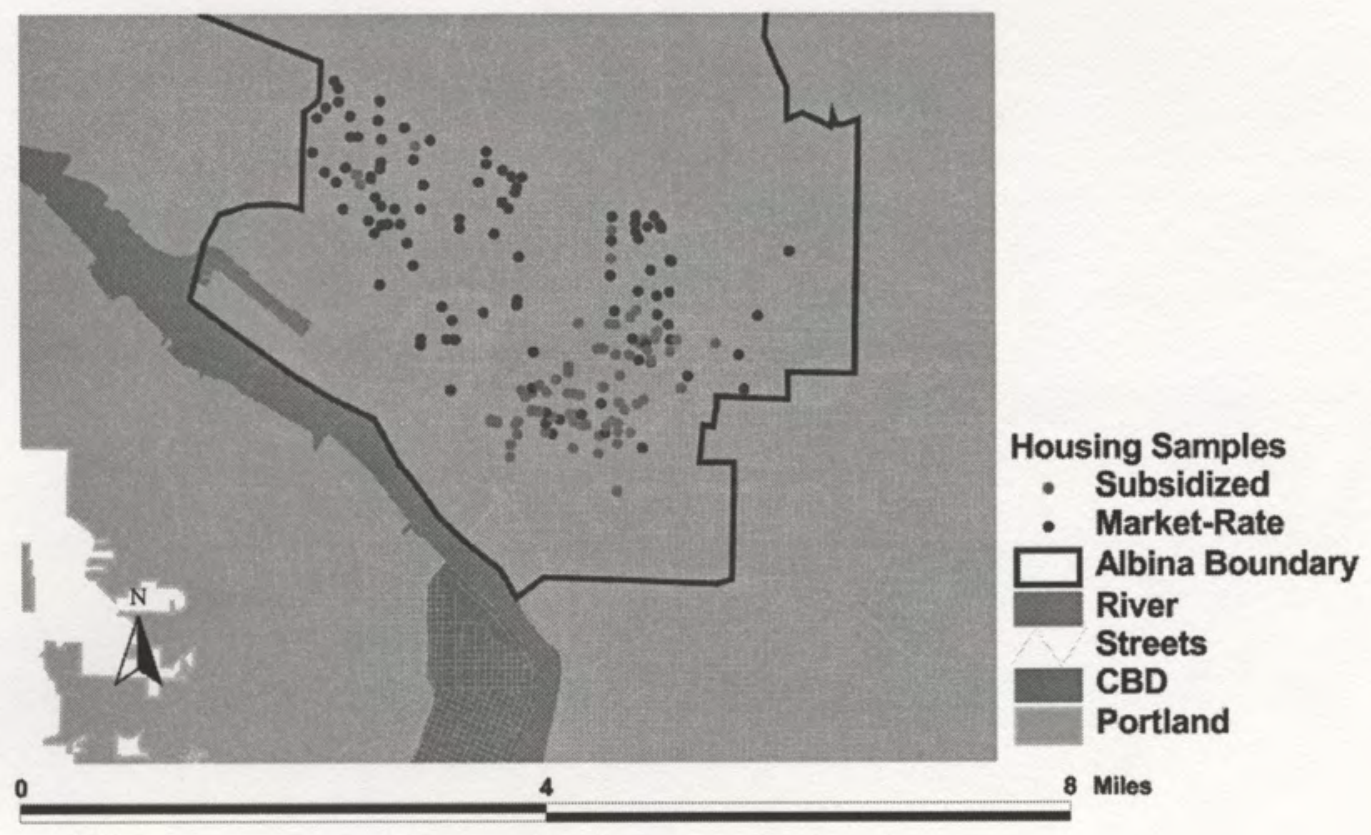

Figure 3.20. Distribution of Market-Rate and Subsidized Sampled Housing with Proximity to Portland's CBD.

Sampled subsidized houses are considerably closer to the CBD with $51 \%$ within 2 miles, while $82 \%$ of the market-rate houses sampled were between 2 and 4.5 miles away. The discrepancy in distance between the sampled groups places subsidized 
houses closer to professional, white-collar jobs located downtown, while the market-rate houses are closer to the blue-collar, industrial jobs located in the northernmost, non-residential section of Albina. The close proximity of the neighborhoods dominated by subsidized sample most likely contributes to the recent changes in upgrading seen in this area. 


\section{Chapter IV. Discussion and Conclusion}

Examining the structural and environmental characteristics revealed the level of quality offered by subsidized and filtered down market-rate housing in Albina. While some differences in quality were observed, most of the characteristics examined indicate subsidized and market-rate housing is presently equal in quality.

The market-rate and subsidized housing exhibited differences in housing cost and size. Sale prices for both samples are relatively close with housing sales in the subsidized sample slightly higher. While market-rate houses have slightly lower sale prices, the subsidized housing is consistently cheaper per square foot. The difference in total price is attributed to the size differences found between the two samples.

Average dwelling size is larger in the subsidized sample. Bigger houses have higher overall sale prices, which explains why the subsidized sample is more expensive per sale. Most of the market-rate houses are located in the Overlook, Arbor Lodge, Kenton, Piedmont, Woodlawn, and Concordia neighborhoods, where housing styles are characteristically smaller. Housing in these neighborhoods primarily consists of newer, one to one-and-a-half story housing styles such as Cape Cod, Minimal Traditionalist, and Ranch. Housing styles in the subsidized sample are one-and-a-half to two stories, modeled after older, larger styles such as the Victorian. 
Exterior physical ratings are equal between the samples, an unexpected finding when comparing older, filtered, housing with newly built houses. In addition, the physical ratings are high, revealing the condition of the housing in both samples is presently in need of few to no repairs. These findings indicate that quality, affordable market-rate housing exists in Albina. In fact, Albina housing that has filtered to affordable levels for low to moderate-level homeowners is in as good condition as the newly built subsidized housing.

While both samples received equal overall physical quality ratings, differences in wear exist between the two types of housing. Subsidized housing appears to be wearing prematurely due to cheap materials and a lack of craftsmanship, while market-rate houses are experiencing typical structural wear. While both the subsidized and market-rate houses are presently of equal physical quality, it is not possible to determine which of the two types of housing will require more maintenance in the upcoming years without further study.

Subsidized houses received slightly higher block ratings than the marketrate houses. Most block ratings observed between the two samples were either good or average. Higher block ratings, good and very good, were found most consistently in the inner most neighborhoods, Boise, Humbolt, King, Vernon, Irvington, and Sabin. The sampled subsidized housing is most concentrated in these neighborhoods. Lower block ratings, average and poor, were most frequently observed in the Woodlawn, Piedmont, Kenton, Arbor Lodge, and Overlook neighborhoods. These neighborhoods contain the highest percentage of market- 
rate housing. While lower block ratings are frequently observed in these outer neighborhoods, some blocks in these neighborhoods received high block ratings. This mix of block ratings is on account of the diversity found in these outer Albina neighborhoods. Pockets of both well and poorly maintained properties can be found throughout the outer Albina neighborhoods. Based on the surveyed block ratings, subsidized housing is located on blocks of higher quality than market-rate housing.

Finally, differences in proximity to neighborhood amenities and crime between the two samples were minimal. The two samples showed little difference in proximity to major grocery stores, neighborhood retail nodes, public transportation, parks, schools, and crime. However, the two samples do differ in the distance to the CBD. Most of the subsidized sample are concentrated in the inner most neighborhoods, Boise, Humbolt, King, Vernon, Irvington, and Sabin, which are one to two miles closer to the CBD than the outlying Overlook, Arbor Lodge, Kenton, Piedmont, Woodlawn, and Concordia neighborhoods. Of the locational quality variables, proximity to the $\mathrm{CBD}$ is the only variable that distinguishes subsidized housing as higher quality; the rest indicate the two samples are of comparable quality.

The difference in the level of quality found between the two samples was unexpected. It was assumed that subsidized housing would be of higher physical quality because it was new, but that subsidized houses may be smaller and located in less desirable neighborhoods than filtered housing because of limited 
development funds. On the contrary, subsidized housing in Albina was of equal physical quality to the market-rate sample and in comparable distance of neighborhood amenities. Also, subsidized housing proved to be of higher quality than market-rate houses with respect to proximity to the CBD.

While this study indicates subsidized housing is presently of higher or equal quality to affordable market-rate housing, the future stability of these findings should be considered. Several factors may influence the presence of high quality, affordable filtered and subsidized housing currently found in Albina. Factors that may influence filtered housing quality and affordability include future maintenance demands, neighborhood filtering, and household incompatibility.

Future maintenance demands may be more expensive than is manageable in filtered housing for low to moderate-income homeowners. In most cases, filtered houses have already seen several decades of wear. Structural decay increases greater as the dwelling ages. If the filtered house has become affordable because of the condition of the dwelling relative to other houses in the area, significant structural damage may already exist. With limited incomes, low to moderateincome households may struggle to make initial repairs inherited upon sale, or in future years may decline to make repairs as the need develops, accelerating the degradation of the structure. Maintenance needs may reduce the affordability of a filtered unit, depleting filtered housing as a quality affordable option for homeownership in low to moderate-income households. 
Neighborhood filtering may be another factor in the elimination of quality filtered affordable housing in Albina. Presently, affordable homeownership opportunities for low to moderate-level incomes exist in Albina's outer neighborhoods - Overlook, Arbor Lodge, Kenton, Piedmont, Woodlawn, and Concordia. The near absence of affordable filtered housing in the inner neighborhoods - Boise, Humbolt, King, Vernon, Irvington, and Sabin - indicates these neighborhoods have filtered up in the past several years. Housing in the inner Albina neighborhoods was recently considered some of the worst in Portland, which led to the establishment of multiple CDC and non-profit agencies in these neighborhoods. These neighborhoods, which house some of the oldest housing in Albina, are no longer affordable to low and moderate-income households because of recent upward filtering. Across Portland, aged housing in inner neighborhoods has been redeveloped or renovated; Albina is the last to follow suit. If the demand for housing in Portland continues at its current rate, the upward filtering of inner Albina neighborhoods may spread outward, making outer neighborhoods less affordable.

Finally, household incompatibility with currently affordable filtered housing may pose issues for future low to moderate-income households. Larger households may not be compatible with the predominantly smaller houses currently available in Albina's affordable market-rate housing. This incompatibility may create crowding issues that will further degrade the quality currently observed in these houses. 
Future factors most likely to influence the quality and availability of subsidized housing include maintenance demands, escalating development costs, and increased competition for non-profit development funds. The need to maintain and repair subsidized housing is inevitable. As with filtered housing, maintenance demands in subsidized housing may create a substantial financial burden for low to moderate-income households. While structural wear may not be immediate in new subsidized housing, the low level of craftsmanship and material quality may accelerate the aging process and necessitate premature repairs. Limited finances will inhibit the ability of low to moderate-income households to make necessary repairs and ultimately degrade the current quality of these houses.

The effects of escalating development costs are already evident in Albina. Subsidized housing has primarily been developed in the inner Albina neighborhoods, where lack of investment in past decades provided a prime location for $\mathrm{CDC}$ and non-profit development. Property was cheap and tax foreclosed lots were abundant. With property prices now increasing and tax foreclosed properties decreasing, CDCs and non-profit developers are being priced out of Albina's inner neighborhoods. Non-profit development of owner-occupied housing in Albina is now shifting from the inner neighborhoods outward, and in some cases, as with the newest HOST development, completely out of Albina. NECDC's collapse is in part on account of rising development costs in their service area. With land prices escalating, NECDC was unable to create housing in inner Albina that was affordable to low and moderate-income households. Escalating development costs 
will inevitably reduce the number of location options for the development of affordable owner-occupied housing in Albina, restricting development to the outer neighborhoods while they continue to be affordable. In some cases, this may result in a decrease in the quality of the surrounding environment. If development costs push subsidized housing to Albina's outer neighborhoods, block ratings will decrease and the distance to the CBD will increase.

In addition to limited location options, increased development costs may contribute to a decrease in housing quality. Housing survey results revealed the use of lower quality materials and a lower level of craftsmanship in subsidized houses. If development costs are increasing, sustaining production may lead to a further reduction in the quality of materials and level of craftsmanship to control costs. Another option to cutting production costs is reducing the size of the dwelling. If housing size is reduced, the level at which subsidized housing currently surpasses filtered, market-rate housing in size and cost per square foot will diminish. Smaller housing will also result in fewer options and a lower level of quality for larger households.

Not only are development costs increasing, the amount of money allocated to produce subsidized housing is decreasing. NECDC's financial difficulties led the agency to pursue for-profit investments to finance affordable housing developments after government funding was cut. Several Albina CDCs currently creating non-ownership housing in the area are discussing mergers in response to shortages in funding (Behrs, 2000; Dunnette, 1997). Resources for developing 
homeownership opportunities for low to moderate-income households in Albina are diminishing. NECDC developed over half of Albina's current subsidized owner occupied housing. With the folding of NECDC, CDC development of affordable housing for homeownership in Albina is near absent. HOST and Habitat for Humanity are now the primary developers of affordable owner-occupied housing in Albina. Reduced spending reduces the number of options for homeownership in low to moderate-income households, ultimately decreasing the level of quality housing available.

Future maintenance demands, neighborhood filtering, household incompatibility, escalating development costs and increased competition for nonprofit development funds are major factors in the stability of the current quality of affordable owner-occupied housing in Portland's Albina Community. These factors may threaten the ability of one or both housing types to continue providing quality affordable homeownership options for low to moderate income households in the Albina community.

Whether housing created by non-profit developers or market-rate housing made affordable through downward filtering create a better option for a low to moderate-income household is presently hard to determine. Once an affordable home is attained either through the market or through a subsidized homeownership program, the owner of the unit is most likely secure in that house and neighborhood. For those needing homes in the future, the risks are greater. Albina is one of the last largely affordable close-in communities in Portland. If the costs 
of developing affordable housing or neighborhood upgrading restrict affordable options in either subsidized or market-rate housing, homeownership may not be an option for future low and moderate income Portland residents.

Future research may reveal the urgency of these factors and determine which type of housing is more or less likely to continue offering high quality affordable housing. Exploring the true costs of developing subsidized housing may reveal total costs outweigh the quality benefits when compared to filtered marketrate housing. The extent of current financial cutbacks and increase in development costs in Albina should further be examined to determine how great a risk it poses to the future of subsidized housing. Additional research on neighborhood market changes and the actual availability of affordable market-rate houses to low and moderate-level income households may reveal competition with higher income households is reducing market-rate options. Many research questions remain and should be examined in order to determine whether quality trends currently observed in Albina will continue to be available to low and moderate income households. 


\section{References}

Aaron, Henry, J.1972. Who Benefits from Federal Housing Policies? Washington DC: Brookings Institute.

Aultman-Hall, Lisa, Roorda, Matthew, and Baetz, Brian W. 1997. Using GIS for Evaluation of Neighborhood Pedestrian Accessibility. Journal of Urban Planning and Development 123(1):10-15.

Baer, William C., and Williamson, Christopher B. 1988. The Filtering of Households and Housing Units. Journal of Planning Literature 3(2):127152.

Barnett, Jim and Suo, Steve. 1996. Albina: Up or Out? Oregonian September 8:A01.

Behrs, Jan. 2000. Community Program Helps Wages Catch Up With Prices. Oregonian July 30:H01.

Berry, Brian L. J. 1979. The Open Housing Question: Race and Housing in Chicago, 1966-1976. Cambridge: Ballinger Publishing Company.

Bourne, Larry S. 1981. Geography of Housing. New York: John Wiley and Sons.

Cannon, Donald S. 1980. The Complete Book of Relative Residential Status and Household Characteristics. Milwaukie: Department of City Development. 
City of Portland Bureau of Housing and Community Development. 2000. Median Income Percentages for 2000. Portland: Bureau of Housing and Community Development.

City of Portland Bureau of Planning. 1993. Adopted Albina Community Plan.

Portland: Bureau of Planning.

City of St Paul Division of Planning - Department of Planning and Economic

Development. 1988. Saint Paul Housing Conditions 1988 Survey. Saint

Paul: Division of Planning - Department of Planning and Economic

Development.

Colean, Miles L. 1947. American Housing: Problems and Prospects. New York:

The Twentieth Century Fund.

Community Development Network. 2000. Guide to CDCs and Nonprofit Housing Developers for Portland, Oregon. Community Development Network.

Cott, Leland, D. 1999. Chicago and Beyond. Harvard Design Magazine Summer:10-11.

Davis, Sam. 1995. Architecture of Affordable Housing. Berkeley: University of California Press.

Downs, Anthony. 1981. Neighborhoods and Urban Development. Washington D.

C.: Brookings Institute.

Dunnette, Paul. 1997. A Humane Habitat. Oregonian January 2:1.

Edel, Matthew and Rothenberg, Jerome. 1972. Readings in Urban Economics. New York: Macmillan Company. 
Fitzgibbon, Joe. 1999. Albina's Blueprint for Success. Oregonian October 11:E03. 2000. Albina Community Takes Stock of Plan Many Residents Sense a Neighborhood Renaissance and Urge Continued Financial Assistance. Oregonian May 22:E02.

Faulstich, James R. 1996. Helping Dreams Come True. Oregonian November 18:C09.

Galster, George. 1996. William Grigsby and the Analysis of Housing Sub Markets and Filtering. Urban Studies 33(10):1997-1805.

Gittell, Ross, and Wilder, Margaret. 1999. CDCs Critical Factors that Influence Success. Journal of Urban Affairs 21(3):341-362.

Greenberg, Michael, Schneider, Dona and Choi, Daiwoo. 1994. Neighborhood Quality. The Geographical Review 84(1):1-15.

Henderson, J. Vernon. 1985. Economic Theory and the Cities, Second Edition. Orlando: Academic Press.

Hickman, Edgar P., Gaines, James P., and Ingram, Jerry F. 1984. Influence of Neighborhood Quality on Residential Property Values. Real Estate Appraiser and Analyst Summer:36-42.

Higgins, Neal. 1996. Metropolitan Portland Real Estate Report 82(Spring). 2000. Metropolitan Portland Real Estate Report 90(Spring). 2001. Metropolitan Portland Real Estate Report 92(Spring). 
Hole, James. 1866. The Homes of the Working Class. London: Longmans, Green and Company, Paternoster Row.

Hunsberger, Brett. 1998. Legacy on the Line. Oregonian February 16:A01.

Kain, J.F. and Quigley, J. M. 1970. Evaluating the Quality of the Residential

Environment. Environment and Planning 2:23-32.

Kristof, Frank. 1972. Federal Housing Policies: Subsidized Production, Filtration, and Objections, Part I. Land Economics 48(4):309-320.

1973. Federal Housing Policies: Subsidized Production, Filtration, and Objections, Part II. Land Economics 49(2):163-174.

Lansing, John B., Clifton, Chales Wade, and Morgan, James N. 1969. New Homes and Poor People: A Study of Chains of Moves. Ann Arbor: Institute for Social Research University of Michigan.

Leven, Charles L., Little, James T., Nourse, Hugh O. 1976. Neighborhood Change: Lessons in the Dynamics of Urban Decay. New York: Praeger Publishers.

Little, James T. 1976. Residential Preferences, Neighborhood Filtering and Neighborhood Change. Journal of Urban Economics 3(1):68-81.

Lowry, Ira S. 1960. Filtering and Housing Standards: A Conceptual Analysis. Land Economics 36(4):362-370.

Lydersen, Kari. 1996. Building on the Dream. Oregonian July 11:1.

Maher, C.A. 1974. Spatial Patterns in Urban Housing Markets: Filtering in Toronto 1953-1971. Canadian Geographer 18(2):108-124. 
Marullo, Sam. 1985. Housing Opportunities and Vacancy Chains. Urban Affairs Quarterly 20(3):364-388.

1983. Racial Differences in Housing Consumption and Filtering. In Remaking the City, ed. John S. Pipkin, Mark La Gory, and Judith R.Blau, pp. 229-253. Albany: State University of New York Press.

Metro Regional Government. 1999. Regional Land Information System (RLIS). Portland: Metro.

Myers, Dowell. 1983. Upward Mobility and the Filtering Process. Journal of Planning and Educational Research 2(2):101-112.

Nourse, Hugh, O. 1973. The Effect of Public Policy on Housing Markets.

Lexington: D.C. Heath and Company.

Oliver, Gordon. 2000. Development Group Faces Demise. Oregonian June 5:E01. Oregonian Staff. 1998. Home at Last. Oregonian October 8:26.

Park, Robert E., Burgess, Ernest, W., and McKenzie, Roderick, D. 1925. The City. Chicago: The University of Chicago Press.

Piper, R.K. 1985. A Computerized Inventory of Housing and Neighborhood Conditions in Lincoln Nebraska. Applied Urban Research 8(4):1-6. Potter, Connie. 1997. HOST Homes. Oregonian March 30:H01.

Quigley, John M. 1999. Why Should Government Play A Role in Housing? Harvard Design Magazine Summer:50-51.

Ratcliff, Richard U. 1949. Urban Land Economics. New York: McGraw-Hill Book Company, Inc. 
Rosen, Kenneth T., and Dienstfrey, Ted. 1999. The Economics of Housing Services in Low Income Neighborhoods. In Urban Problems and Community Development, ed. Ronald F Ferguson and William T Dickens, pp. Washington DC: Brookings Institution Press.

Rubenstein, Sara. 1999. Concerns Build at Housing Agency as Interest Stray. Oregonian June 6:A01.

Salins, Peter D. 1980. The Ecology of Housing Destruction: Economic Effects of Public Intervention in the Housing Market. New York: New York University Press.

Schill, Michael H. 1994. The Role of the Nonprofit Sector in Low Income Housing Production: A Comparitive Perspective. Urban Affairs Quarterly 30(1):74102.

Smith, Wallace F. 1970. Housing: The Social and Economic Elements. Berkeley: University of California Press.

Sullivan, Mercer L. 1993. Community Development as an Anti-Poverty Strategy. Part of the National Center for Children in Poverty Conference. 1-8. Thibdeau, Thomas G. 1997. Introduction. Journal of Real Estate Finance and Economics 14(15).

US Census. 1996. American Community Survey Data. Washington DC: US Census. 
US Department of Housing and Urban Development. 1996. New American Neighborhoods: Building Homeownership Zones to Revitalize Our Nation's Communities. Washington DC: US Department of Housing and Urban Development.

Vidal, Avis C. 1997. Can Community Development Reinvent Itself? American Planners Association Journal 63(4):429-438.

Weicher, John C., and Thibodeau, Thomas G. 1988. Filtering and Housing Markets: An Empirical Analysis. Journal of Urban Economics 23:21-40. 
Appendix A - Examples of Structural Quality Survey Model 


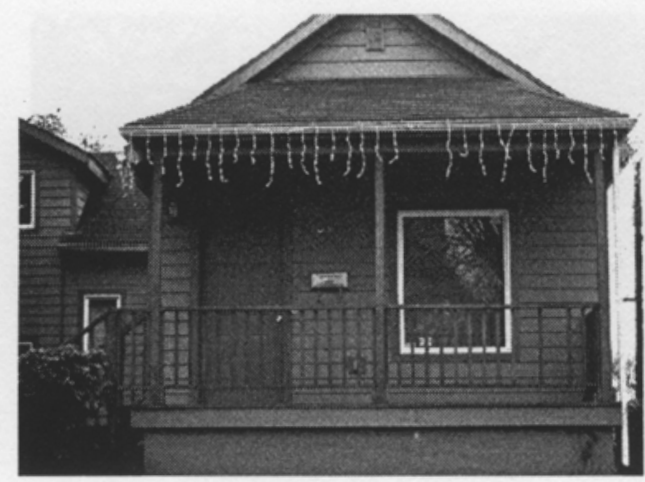

Roof: 2

Walls: 1

Door: 1

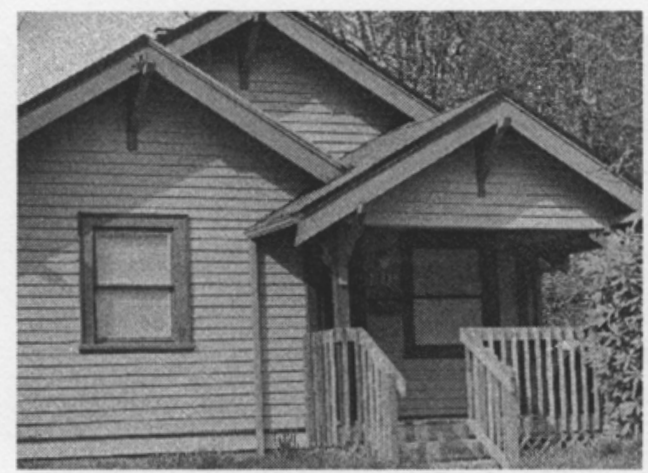

Roof: 2

Walls: 2

Door: 2

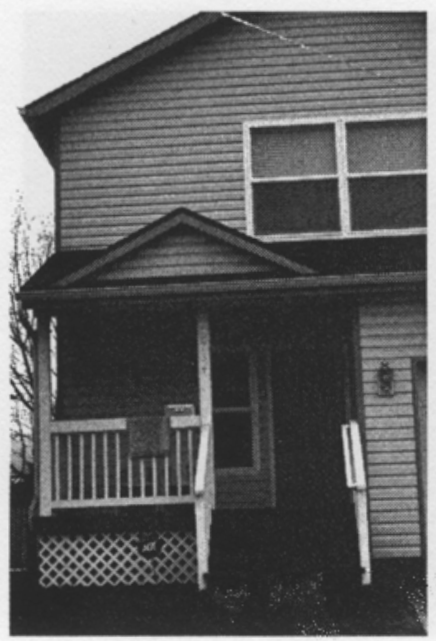

Yard: 2
Roof: 1

Eaves: 1

Walls: 1

Windows: 1

Door: 1

Porch: 1

Yard: 1

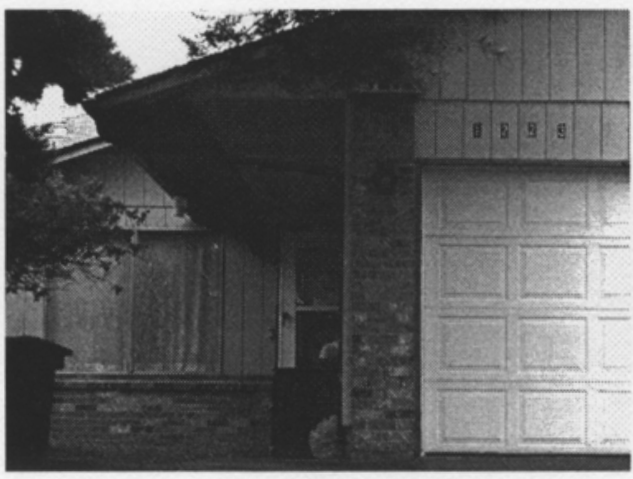

Roof: 1

Eaves: 1

Walls: 1

Door: 1

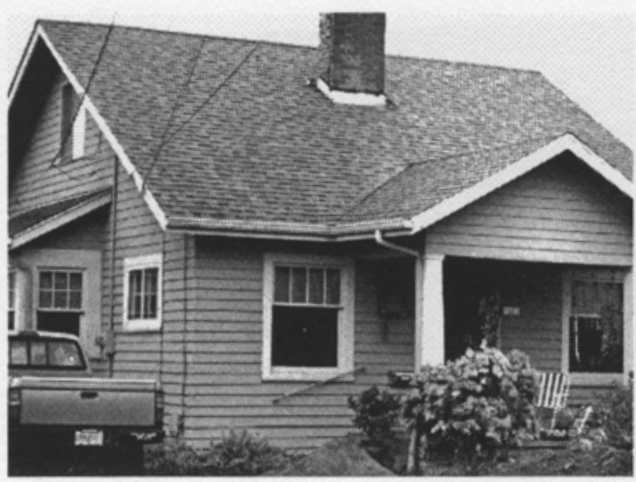

Roof: 1

Walls: 1

Door: 1
Eaves: 2

Windows: 1

Porch: 2

Yard: 2

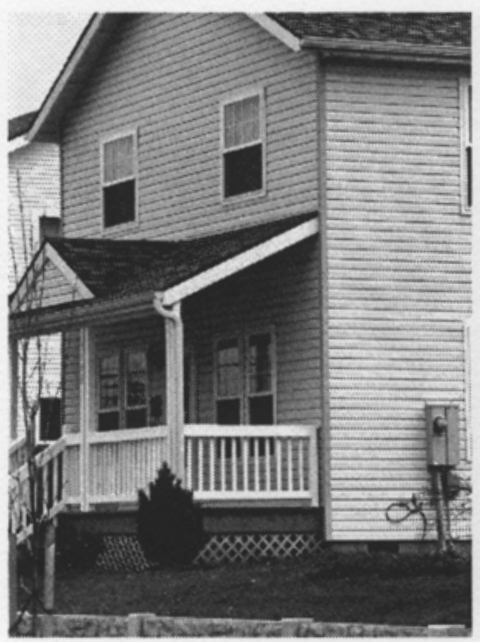

Roof: 1

Eaves: 1

Walls: 1

Windows: 1

Door: 1

Porch: 1

Yard: 1 


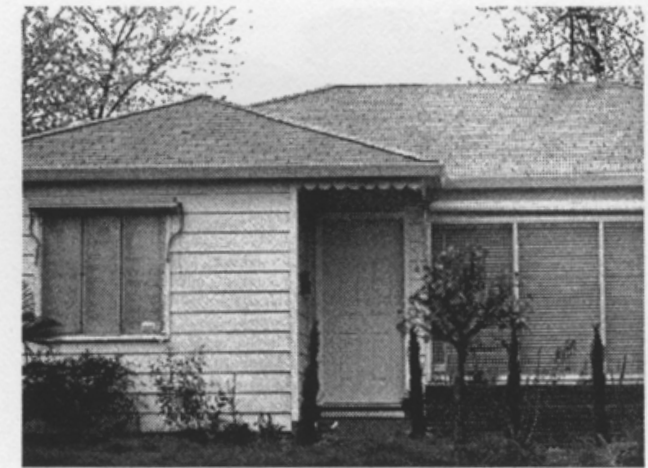

Roof: 1

Walls: 1

Door: 1

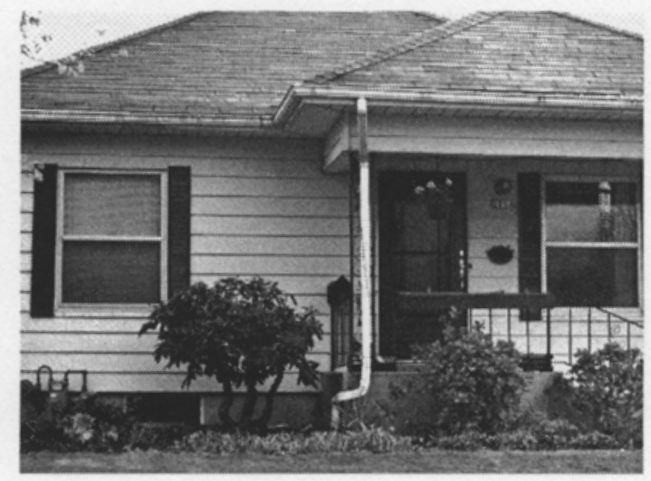

Roof: 1

Walls: 1

Door: 1

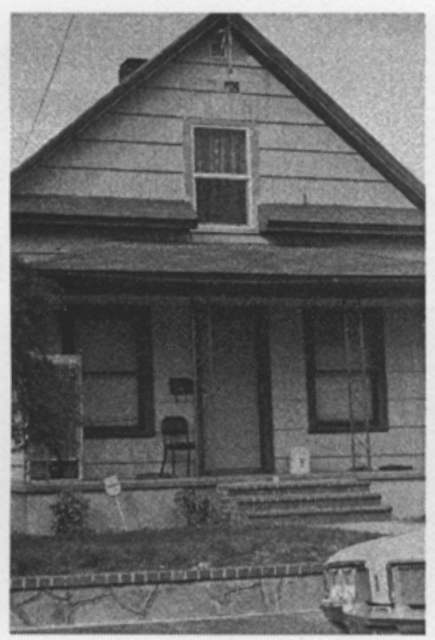

Windows: 1

Yard: 1
Roof: 2

Eaves: 2

Walls: 2

Windows: 2

Door: 2

Porch: 1

Yard: 1

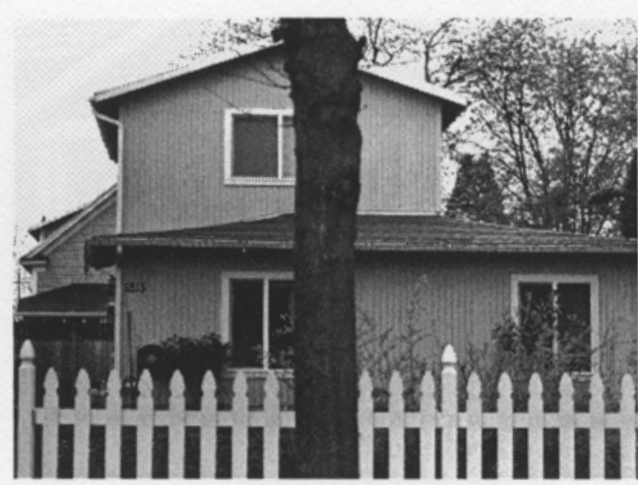

Roof: 1

Walls: 1

Door: 1

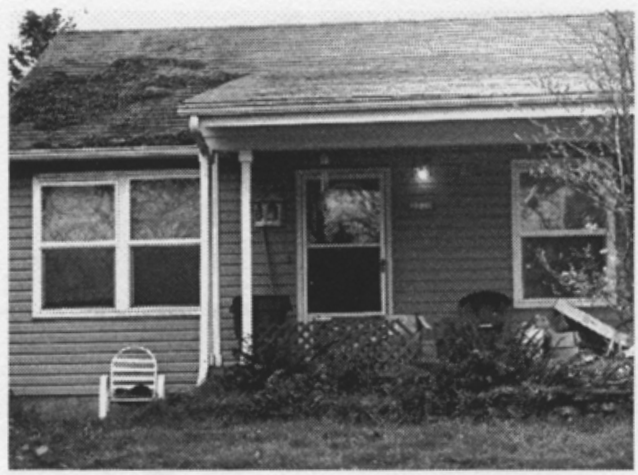

Roof: 2

Walls: 1

Eaves: 2

Windows: 1

Door: 1

Porch: 2

Yard: 2

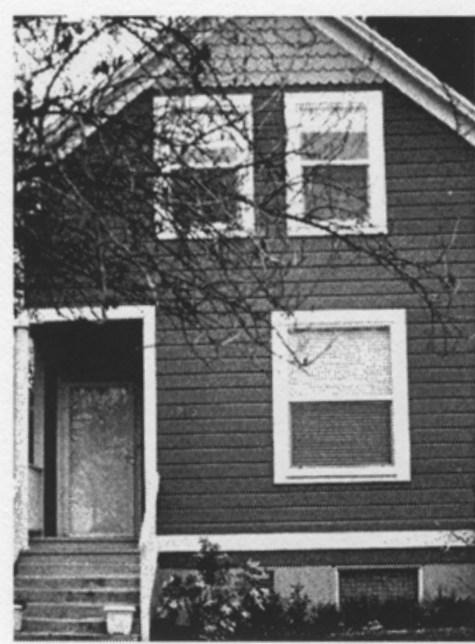

Roof: 1

Eaves: 2

Walls: 1

Windows: 1

Door: 1

Porch: 2

Yard: 1 


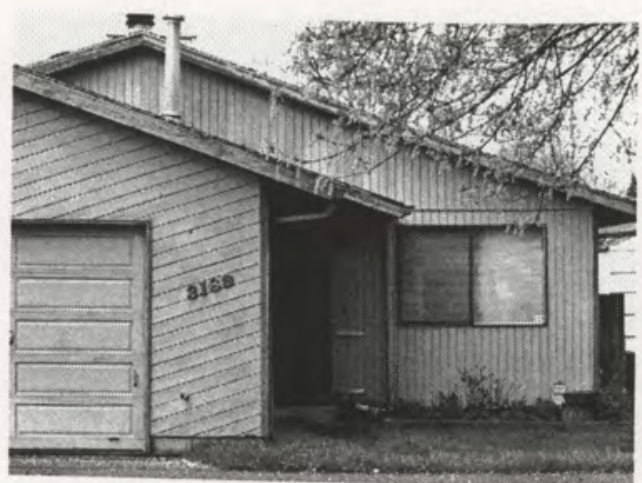

Roof: 2

Walls: 2

Door: 1

Eaves: 2

Windows: 1

Porch: 2

Yard: 2

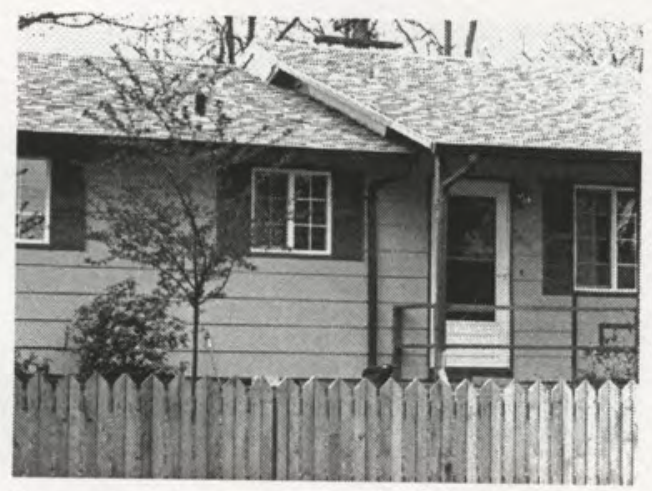

Roof: 1

Walls: 1

Door: 1
Eaves: 2

Windows: 1

Porch: 1

Yard: 1

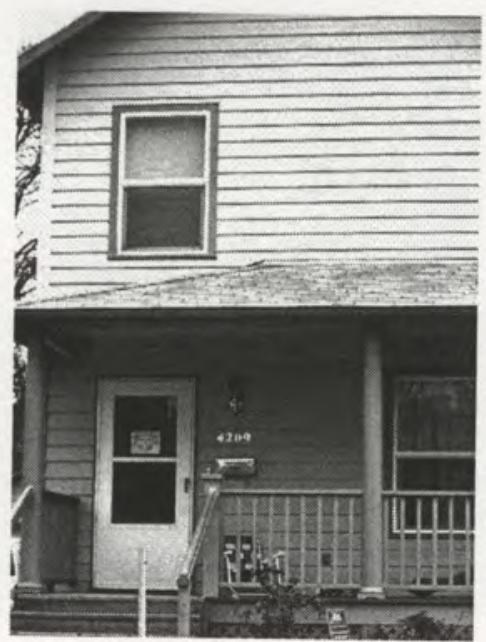

Roof: 1

Eaves: 2

Walls: 1

Windows: 1

Door: 1

Porch: 2

Yard: 1

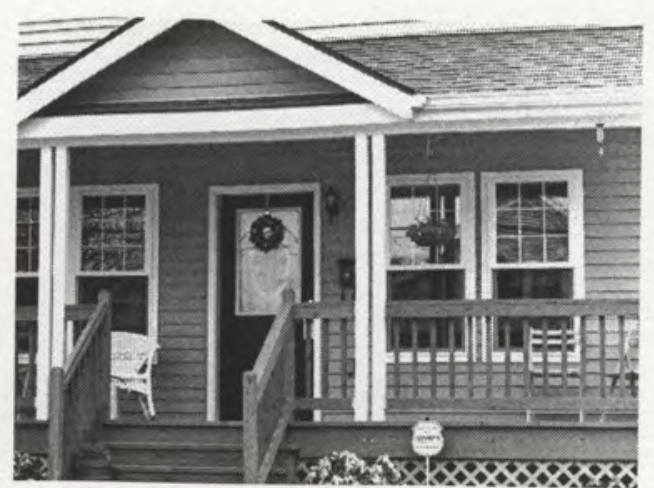

\section{Roof: 1}

Walls: 1

Door: 1
Eaves: 1

Windows: 1

Porch: 1

Yard: 1

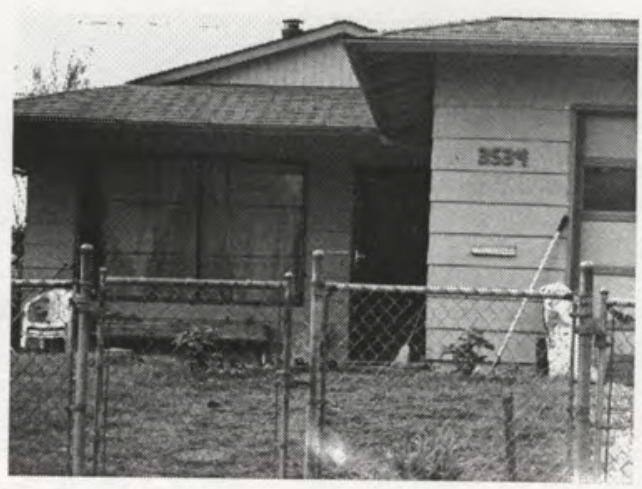

Roof: 2

Walls: 2

Door: 1
Eaves: 2

Windows: 2

Yard: 2

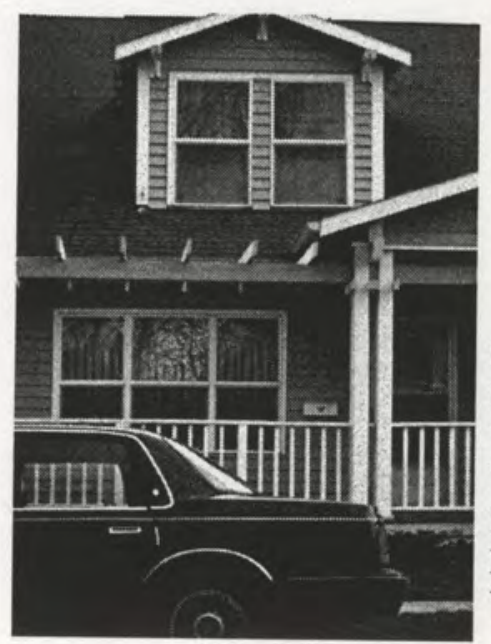

Roof: 2

Eaves: 2

Walls: 1

Windows: 1

Door: 2

Porch: 2

Yard: 1 


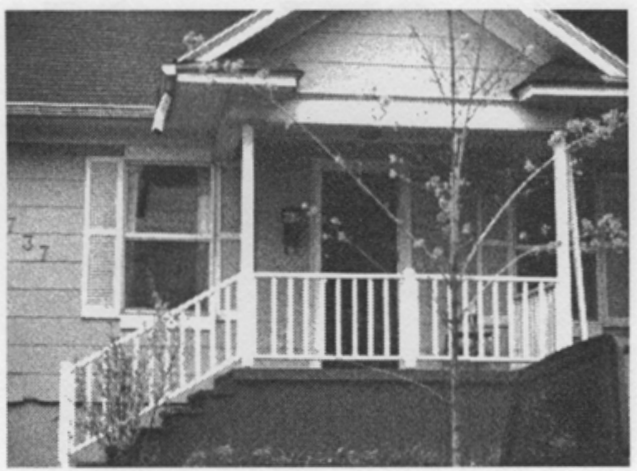

Roof: 2

Walls: 1

Door: 1
Eaves: 2

Windows: 2

Porch: 1
Yard: 2

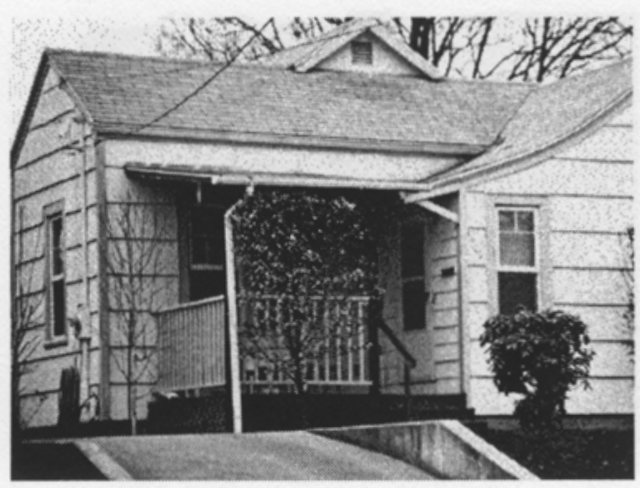

Roof: 2

Walls: 2

Door: 1
Eaves: 2

Windows: 2

Porch: 2

Yard: 1

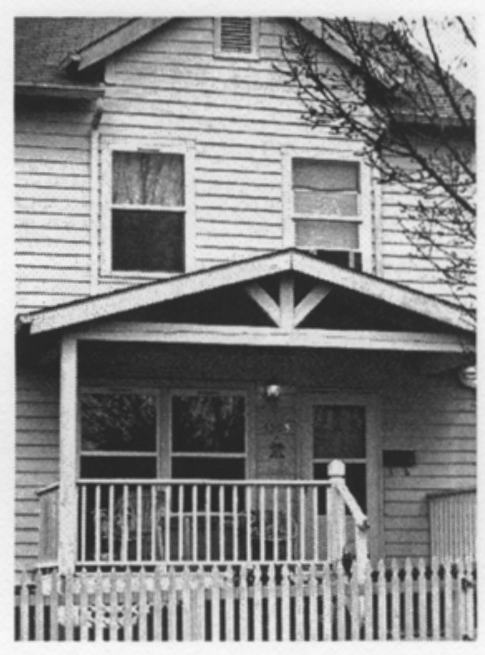

Roof: 2

Eaves: 2

Walls: 2

Windows: 2

Door: 2

Porch: 3

Yard: 1

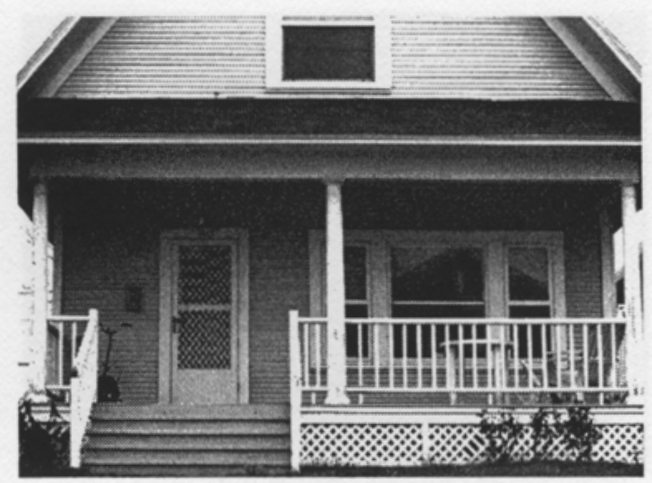

Roof: 3

Walls: 2

Door: 2

Eaves: 2

Windows: 2

Porch: 2

Yard: 2

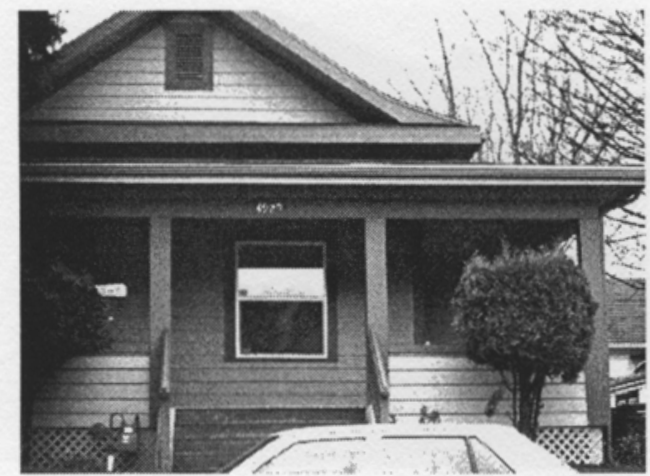

Roof: 2

Walls: 1

Door: 1

Eaves: 2

Windows: 1

Porch: 2

Yard: 2

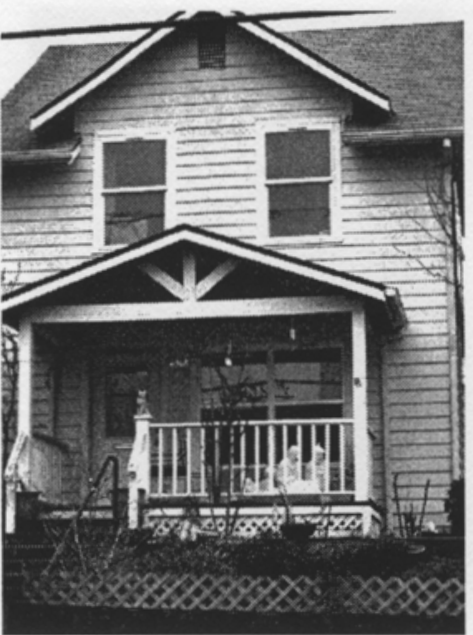

Roof: 2

Eaves: 2

Walls: 2

Windows: 1

Door: 1

Porch: 2

Yard: 2 


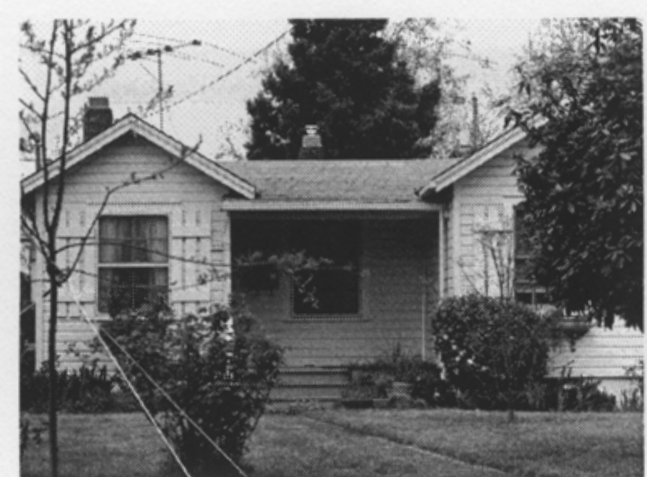

Roof: 2

Walls: 1

Door: 1

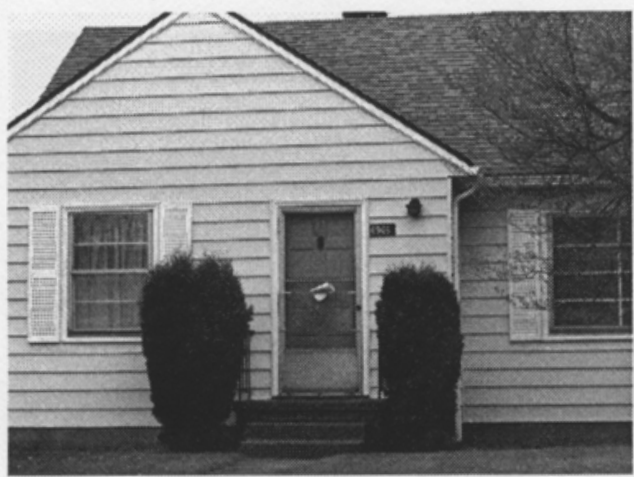

Roof: 1

Walls: 1

Door: 1

Eaves: 1

Windows: 1

Porch: 1

Yard: 1

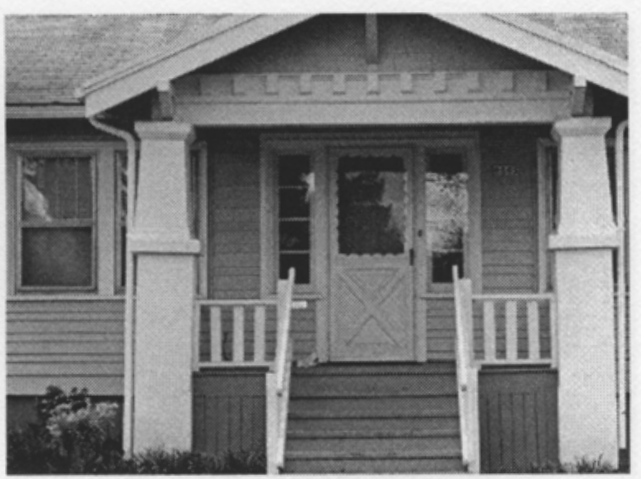

Roof: 2

Walls: 1

Door: 1
Eaves: 1

Windows: 1

Porch: 2
Yard: 1

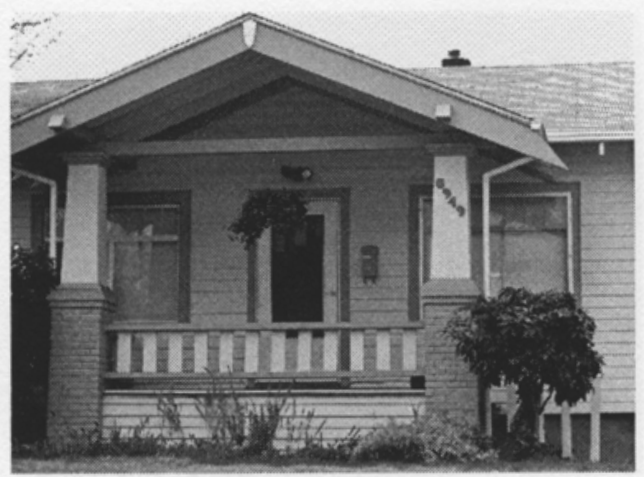

Roof: 2

Walls: 1

Door: 1
Eaves: 1

Windows: 1

Porch: 1

Yard: 1

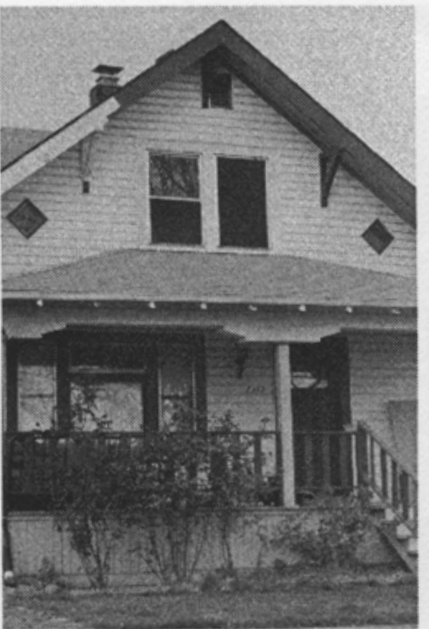

Roof: 1

Eaves: 2

Walls: 1

Windows: 1

Door: 1

Porch: 2

Yard: 2 


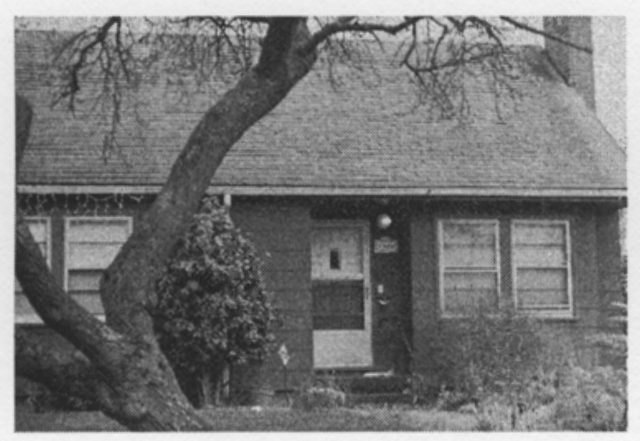

Roof: 2

Walls: 1

Door: 1

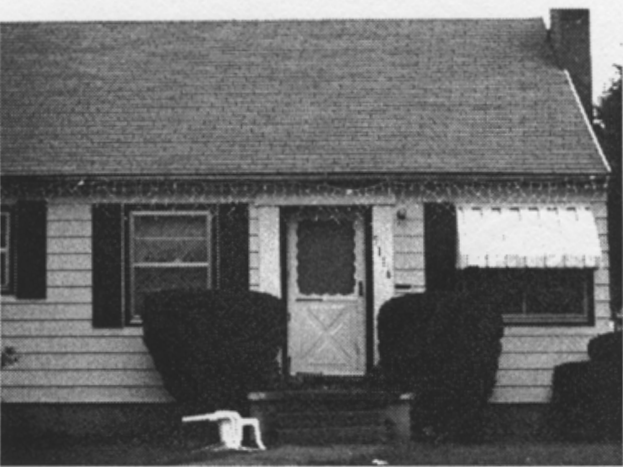

Roof: 1

Walls: 1

Door: 2

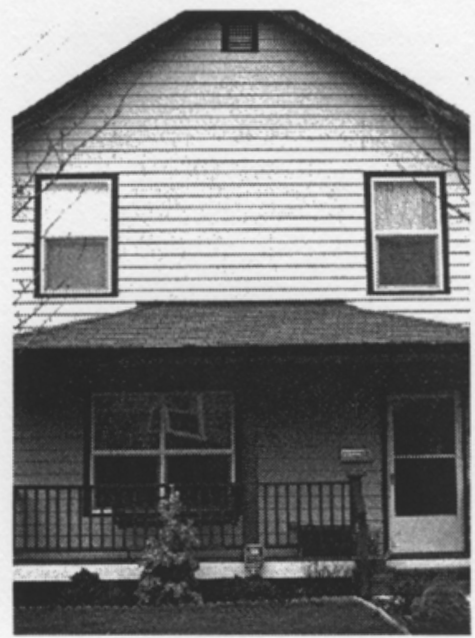

Eaves: 1

Windows: 1

Porch: 2
Yard: 1

Eaves: 2

Windows: 1

Porch: 2

Yard: 1

Roof: 2

Eaves: 2

Walls: 1

Windows: 1

Door: 1

Porch: 1

Yard: 1

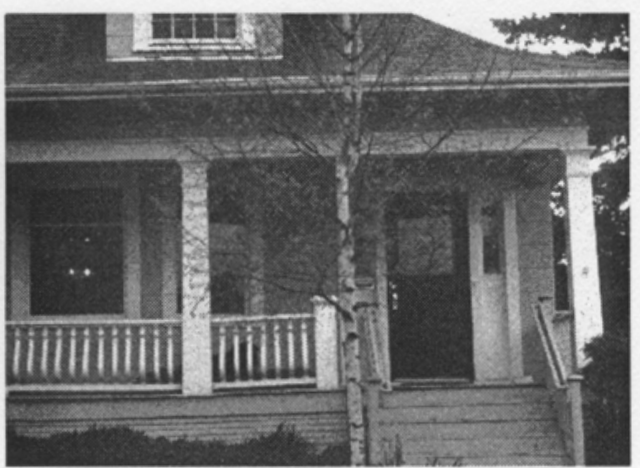

Roof: 1

Walls: 2

Door: 1

Eaves: 1

Windows: 1

Porch: 2

Yard: 1

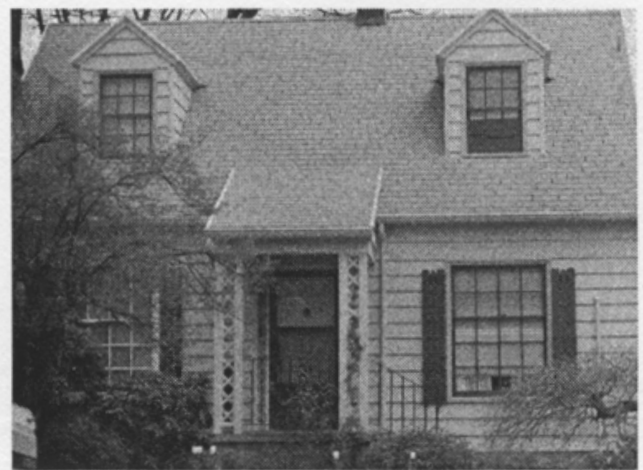

Roof: 1

Walls: 1

Door: 1

Eaves: 1

Windows: 1

Porch: 1

Yard: 1

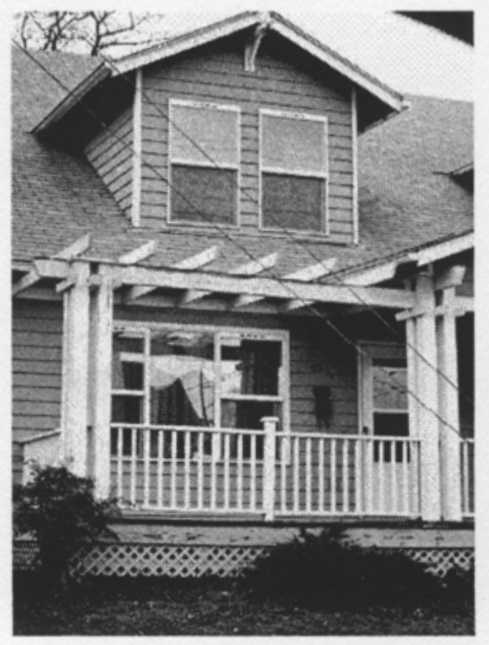

Roof: 1

Eaves: 2

Walls: 1

Windows: 1

Door: 1

Porch: 3

Yard: 2 
Appendix B - Survey Data 


\begin{tabular}{|l|l|l|l|l|l|}
\hline ID & SQ_FT & COST_SQFT & YEAR_SOLD & YEAR_BUILT & SALE_PRICE \\
\hline 1 & 1,275 & $\$ 89$ & 1994 & 1933 & $\$ 113,960$ \\
\hline 2 & 1,546 & $\$ 59$ & 1994 & 1993 & $\$ 91,245$ \\
\hline 4 & 1,224 & $\$ 82$ & 1994 & 1993 & $\$ 100,100$ \\
\hline 5 & 1,248 & $\$ 87$ & 1996 & 1996 & $\$ 108,800$ \\
\hline 6 & 1,285 & $\$ 92$ & 1994 & 1994 & $\$ 118,580$ \\
\hline 7 & 1,936 & $\$ 52$ & 1994 & 1914 & $\$ 100,100$ \\
\hline 8 & 1,968 & $\$ 46$ & 2000 & 1900 & $\$ 90,500$ \\
\hline 8 & 1,248 & $\$ 66$ & 1999 & 1979 & $\$ 82,425$ \\
\hline 9 & 1,041 & $\$ 104$ & 1994 & 1911 & $\$ 107,800$ \\
\hline 10 & 1,104 & $\$ 93$ & 1996 & 1892 & $\$ 102,400$ \\
\hline 11 & 1,410 & $\$ 85$ & 1995 & 1906 & $\$ 120,400$ \\
\hline 12 & 2,572 & $\$ 75$ & 1996 & 1907 & $\$ 192,000$ \\
\hline 13 & 1,285 & $\$ 87$ & 1995 & 1995 & $\$ 112,000$ \\
\hline 14 & 1,248 & $\$ 80$ & 1994 & 1992 & $\$ 100,100$ \\
\hline 15 & 1,022 & $\$ 96$ & 1996 & 1910 & $\$ 98,560$ \\
\hline 16 & 803 & $\$ 109$ & 1994 & 1922 & $\$ 87,780$ \\
\hline 16 & 803 & $\$ 117$ & 2000 & 1922 & $\$ 94,000$ \\
\hline 17 & 1,344 & $\$ 69$ & 1995 & 1895 & $\$ 92,400$ \\
\hline 18 & 1,334 & $\$ 86$ & 1995 & 1995 & $\$ 114,100$ \\
\hline 18 & 1,248 & $\$ 88$ & 1996 & 1996 & $\$ 109,504$ \\
\hline 19 & 1,312 & $\$ 86$ & 1995 & 1995 & $\$ 112,700$ \\
\hline 20 & 1,312 & $\$ 85$ & 1995 & 1995 & $\$ 112,000$ \\
\hline 20 & 1,285 & $\$ 92$ & 1994 & 1993 & $\$ 118,580$ \\
\hline 20 & 1,275 & $\$ 95$ & 1994 & 1994 & $\$ 120,890$ \\
\hline 21 & 1,248 & $\$ 93$ & 1994 & 1993 & $\$ 116,270$ \\
\hline 22 & 1,248 & $\$ 87$ & 1996 & 1965 & $\$ 108,800$ \\
\hline 22 & 1,248 & $\$ 93$ & 1994 & 1994 & $\$ 116,270$ \\
\hline 23 & 1,285 & $\$ 86$ & 1994 & 1992 & $\$ 110,880$ \\
\hline 24 & 1,285 & $\$ 71$ & 1998 & 1998 & $\$ 91,560$ \\
\hline 25 & 1,285 & $\$ 77$ & 1996 & 1918 & $\$ 98,650$ \\
\hline 26 & 1,285 & $\$ 92$ & 1995 & 1995 & $\$ 117,600$ \\
\hline 27 & 1,248 & $\$ 91$ & 1995 & 1995 & $\$ 114,100$ \\
\hline 28 & 1,248 & $\$ 96$ & 1994 & 1994 & $\$ 120,120$ \\
\hline 29 & 1,248 & $\$ 88$ & 1995 & 1995 & $\$ 109,900$ \\
\hline 30 & 1,248 & $\$ 86$ & 1996 & 1996 & $\$ 107,520$ \\
\hline 31 & 1,248 & $\$ 114$ & 1994 & 1994 & $\$ 142,450$ \\
\hline 32 & 1,224 & $\$ 92$ & 1995 & 1995 & $\$ 112,000$ \\
\hline 33 & 1,224 & $\$ 92$ & 1995 & 1995 & $\$ 112,000$ \\
\hline 34 & 1,224 & $\$ 92$ & 1995 & 1995 & $\$ 112,000$ \\
\hline 35 & 1,224 & $\$ 85$ & 1994 & 1993 & $\$ 103,950$ \\
\hline 36 & 1,224 & $\$ 98$ & 1994 & 1994 & $\$ 120,120$ \\
\hline 37 & 1,224 & $\$ 98$ & 1994 & 1994 & $\$ 120,120$ \\
\hline 38 & 1,538 & $\$ 76$ & 1996 & 1996 & $\$ 116,927$ \\
\hline 39 & 970 & $\$ 105$ & 1994 & 1994 & $\$ 101,640$ \\
\hline 40 & 1,518 & $\$ 62$ & 1996 & 1996 & $\$ 94,720$ \\
\hline 41 & 1,320 & $\$ 81$ & 1996 & 1996 & $\$ 107,520$ \\
\hline 42 & 1,514 & $\$ 69$ & 1994 & 1994 & $\$ 104,720$ \\
\hline 43 & 1,514 & $\$ 67$ & 1994 & 1994 & $\$ 101,640$ \\
\hline 44 & 1,275 & $\$ 94$ & 1995 & 1995 & $\$ 120,400$ \\
\hline 45 & 1,275 & $\$ 89$ & 1994 & 1994 & $\$ 113,960$ \\
\hline & & & & & \\
\hline
\end{tabular}




\begin{tabular}{|l|l|l|l|l|l|}
\hline ID & SQ_FT & COST_SQFT & YEAR_SOLD & YEAR_BUILT & SALE_PRICE \\
\hline 46 & 1,275 & $\$ 92$ & 1994 & 1994 & $\$ 117,040$ \\
\hline 47 & 1,275 & $\$ 85$ & 1994 & 1994 & $\$ 107,800$ \\
\hline 48 & 1,275 & $\$ 97$ & 1994 & 1994 & $\$ 123,200$ \\
\hline 49 & 1,275 & $\$ 91$ & 1994 & 1994 & $\$ 115,654$ \\
\hline 50 & 1,275 & $\$ 94$ & 1995 & 1995 & $\$ 120,400$ \\
\hline 51 & 934 & $\$ 101$ & 1996 & 1905 & $\$ 94,720$ \\
\hline 52 & 1,204 & $\$ 90$ & 1994 & 1908 & $\$ 107,800$ \\
\hline 53 & 1,272 & $\$ 92$ & 1995 & 1910 & $\$ 116,620$ \\
\hline 54 & 1,128 & $\$ 81$ & 1996 & 1907 & $\$ 91,775$ \\
\hline 55 & 1,044 & $\$ 104$ & 2000 & 1908 & $\$ 109,000$ \\
\hline 56 & 681 & $\$ 137$ & 2000 & 1951 & $\$ 93,000$ \\
\hline 57 & 1,008 & $\$ 119$ & 2000 & 1925 & $\$ 119,500$ \\
\hline 58 & 1,862 & $\$ 48$ & 2000 & 1908 & $\$ 90,000$ \\
\hline 59 & 600 & $\$ 98$ & 2000 & 1950 & $\$ 58,500$ \\
\hline 60 & 1,612 & $\$ 75$ & 2000 & 1940 & $\$ 120,950$ \\
\hline 61 & 600 & $\$ 146$ & 2000 & 1950 & $\$ 87,500$ \\
\hline 62 & 864 & $\$ 96$ & 2000 & 1951 & $\$ 83,000$ \\
\hline 63 & 1,300 & $\$ 94$ & 2000 & 1922 & $\$ 122,000$ \\
\hline 64 & 1,416 & $\$ 69$ & 2000 & 1910 & $\$ 97,745$ \\
\hline 65 & 1,744 & $\$ 63$ & 2000 & 1909 & $\$ 110,000$ \\
\hline 66 & 772 & $\$ 110$ & 2000 & 1927 & $\$ 85,195$ \\
\hline 67 & 528 & $\$ 155$ & 2000 & 1919 & $\$ 82,000$ \\
\hline 68 & 960 & $\$ 120$ & 2000 & 1962 & $\$ 115,000$ \\
\hline 69 & 660 & $\$ 141$ & 2000 & 1924 & $\$ 93,350$ \\
\hline 70 & 672 & $\$ 165$ & 2000 & 1924 & $\$ 11,000$ \\
\hline 71 & 1,626 & $\$ 66$ & 2000 & 1910 & $\$ 108,000$ \\
\hline 73 & 1,382 & $\$ 36$ & 2000 & 1909 & $\$ 50,000$ \\
\hline 74 & 1,382 & $\$ 45$ & 2000 & 1920 & $\$ 62,000$ \\
\hline 75 & 1,484 & $\$ 73$ & 2000 & 1926 & $\$ 108,000$ \\
\hline 77 & 953 & $\$ 94$ & 2000 & 1909 & $\$ 89,900$ \\
\hline 78 & 870 & $\$ 138$ & 2000 & 1927 & $\$ 119,900$ \\
\hline 79 & 816 & $\$ 94$ & 2000 & 1912 & $\$ 77,000$ \\
\hline 80 & 1,246 & $\$ 40$ & 2000 & 1972 & $\$ 49,640$ \\
\hline 81 & 960 & $\$ 120$ & 2000 & 1962 & $\$ 115,000$ \\
\hline 82 & 718 & $\$ 153$ & 2000 & 1924 & $\$ 110,000$ \\
\hline 83 & 1,519 & $\$ 82$ & 2000 & 1955 & $\$ 125,000$ \\
\hline 84 & 705 & $\$ 111$ & 2000 & 1922 & $\$ 78,000$ \\
\hline 85 & 860 & $\$ 97$ & 2000 & 1926 & $\$ 83,500$ \\
\hline 86 & 1,232 & $\$ 87$ & 2000 & 1910 & $\$ 107,000$ \\
\hline 87 & 960 & $\$ 109$ & 2000 & 1980 & $\$ 105,000$ \\
\hline 88 & 1,545 & $\$ 46$ & 2000 & 1890 & $\$ 70,500$ \\
\hline 89 & 1,134 & $\$ 106$ & 2000 & 1974 & $\$ 120,000$ \\
\hline 90 & 624 & $\$ 125$ & 2000 & 1921 & $\$ 78,200$ \\
\hline 91 & 782 & $\$ 138$ & 2000 & 1919 & $\$ 108,000$ \\
\hline 92 & 1,384 & $\$ 73$ & 2000 & 1948 & $\$ 100,433$ \\
\hline 93 & 1,166 & $\$ 77$ & 2000 & 1945 & $\$ 89,500$ \\
\hline 94 & 1,306 & $\$ 75$ & 2000 & 1928 & $\$ 98,000$ \\
\hline 95 & 1,189 & $\$ 57$ & 2000 & 1926 & $\$ 68,100$ \\
\hline 96 & 954 & $\$ 78$ & 2000 & 1892 & $\$ 74,400$ \\
\hline 97 & 1,677 & $\$ 66$ & 2000 & 1916 & $\$ 110,706$ \\
\hline & & & & & \\
\hline
\end{tabular}




\begin{tabular}{|l|l|l|l|l|l|}
\hline ID & SQ_FT & COST_SQFT & YEAR_SOLD & YEAR_BUILT & SALE_PRICE \\
\hline 98 & 888 & $\$ 88$ & 1999 & 1999 & $\$ 77,700$ \\
\hline 99 & 1,047 & $\$ 114$ & 1999 & 1911 & $\$ 119,595$ \\
\hline 100 & 1,232 & $\$ 80$ & 2000 & 1925 & $\$ 98,500$ \\
\hline 102 & 1,232 & $\$ 98$ & 1997 & 1997 & $\$ 121,095$ \\
\hline 103 & 1,720 & $\$ 46$ & 2000 & 1910 & $\$ 79,900$ \\
\hline 104 & 1,040 & $\$ 115$ & 2000 & 1911 & $\$ 120,000$ \\
\hline 106 & 1,308 & $\$ 81$ & 2000 & 1996 & $\$ 105,500$ \\
\hline 107 & 859 & $\$ 137$ & 2000 & 1911 & $\$ 117,900$ \\
\hline 108 & 1,285 & $\$ 97$ & 1998 & 1998 & $\$ 125,241$ \\
\hline 109 & 1,285 & $\$ 74$ & 1997 & 1997 & $\$ 94,717$ \\
\hline 110 & 1,200 & $\$ 86$ & 1998 & 1997 & $\$ 103,550$ \\
\hline 111 & 1,200 & $\$ 86$ & 1998 & 1997 & $\$ 103,550$ \\
\hline 112 & 1,120 & $\$ 50$ & 1999 & 1999 & $\$ 55,650$ \\
\hline 113 & 1,120 & $\$ 50$ & 1999 & 1999 & $\$ 55,650$ \\
\hline 114 & 1,275 & $\$ 44$ & 1999 & 1999 & $\$ 55,650$ \\
\hline 115 & 1,275 & $\$ 44$ & 1999 & 1999 & $\$ 55,650$ \\
\hline 116 & 1,110 & $\$ 50$ & 1999 & 1999 & $\$ 55,650$ \\
\hline 117 & 1,110 & $\$ 50$ & 1999 & 1999 & $\$ 55,650$ \\
\hline 118 & 1,110 & $\$ 50$ & 1999 & 1999 & $\$ 55,650$ \\
\hline 119 & 1,606 & $\$ 65$ & 2000 & 1911 & $\$ 105,000$ \\
\hline 120 & 1,542 & $\$ 71$ & 2000 & 1908 & $\$ 109,500$ \\
\hline 121 & 1,224 & $\$ 51$ & 2000 & 1911 & $\$ 62,750$ \\
\hline 122 & 1,462 & $\$ 62$ & 1999 & 1999 & $\$ 90,571$ \\
\hline 123 & 916 & $\$ 128$ & 2000 & 1909 & $\$ 117,500$ \\
\hline 125 & 806 & $\$ 119$ & 2000 & 1927 & $\$ 96,000$ \\
\hline 126 & 1,204 & $\$ 93$ & 2000 & 1913 & $\$ 112,000$ \\
\hline 127 & 1,030 & $\$ 87$ & 2000 & 1917 & $\$ 90,000$ \\
\hline 128 & 817 & $\$ 55$ & 2000 & 1923 & $\$ 45,000$ \\
\hline 129 & 704 & $\$ 60$ & 2000 & 1927 & $\$ 42,111$ \\
\hline 130 & 1,055 & $\$ 50$ & 2000 & 2000 & $\$ 53,000$ \\
\hline 131 & 1,296 & $\$ 41$ & 2000 & 1905 & $\$ 53,000$ \\
\hline 132 & 1,114 & $\$ 50$ & 1999 & 1999 & $\$ 55,650$ \\
\hline 133 & 1,008 & $\$ 99$ & 2000 & 1981 & $\$ 100,000$ \\
\hline 134 & 1,308 & $\$ 81$ & 2000 & 1906 & $\$ 106,500$ \\
\hline 135 & 1,140 & $\$ 96$ & 2000 & 1923 & $\$ 109,900$ \\
\hline 136 & 1,176 & $\$ 100$ & 1999 & 1999 & $\$ 117,600$ \\
\hline 137 & 1,285 & $\$ 94$ & 1997 & 1998 & $\$ 120,510$ \\
\hline 138 & 975 & $\$ 59$ & 1998 & 1998 & $\$ 57,770$ \\
\hline 139 & 975 & $\$ 59$ & 1998 & 1998 & $\$ 57,770$ \\
\hline 140 & 720 & $\$ 139$ & 2000 & 1927 & $\$ 100,000$ \\
\hline 141 & 1,012 & $\$ 96$ & 2000 & 1908 & $\$ 97,200$ \\
\hline 142 & 1,290 & $\$ 94$ & 2000 & 1908 & $\$ 121,000$ \\
\hline 143 & 1,008 & $\$ 119$ & 2000 & 1906 & $\$ 119,900$ \\
\hline 144 & 1,948 & $\$ 59$ & 2000 & 1998 & $\$ 115,000$ \\
\hline 145 & 1,560 & $\$ 83$ & 2000 & 2000 & $\$ 129,000$ \\
\hline 146 & 1,580 & $\$ 90$ & 1998 & 1998 & $\$ 141,700$ \\
\hline 147 & 1,375 & $\$ 94$ & 1997 & 1998 & $\$ 128,700$ \\
\hline 148 & 1,472 & $\$ 84$ & 2000 & 1912 & $\$ 123,000$ \\
\hline 149 & 1,274 & $\$ 80$ & 2000 & 1944 & $\$ 102,000$ \\
\hline 150 & 972 & $\$ 98$ & 2000 & 1906 & $\$ 95,000$ \\
\hline & & & & & \\
\hline
\end{tabular}




\begin{tabular}{|l|l|l|l|l|l|}
\hline ID & SQ_FT & COST_SQFT & YEAR_SOLD & YEAR_BUILT & SALE_PRICE \\
\hline 151 & 1,370 & $\$ 63$ & 2000 & 1909 & $\$ 86,000$ \\
\hline 152 & 744 & $\$ 147$ & 2000 & 1919 & $\$ 109,000$ \\
\hline 153 & 668 & $\$ 179$ & 2000 & 1923 & $\$ 119,500$ \\
\hline 154 & 1,690 & $\$ 70$ & 2000 & 1937 & $\$ 118,000$ \\
\hline 155 & 760 & $\$ 139$ & 2000 & 1924 & $\$ 106,000$ \\
\hline 156 & 840 & $\$ 119$ & 2000 & 1927 & $\$ 99,900$ \\
\hline 157 & 1,279 & $\$ 96$ & 2000 & 1942 & $\$ 123,000$ \\
\hline 159 & 920 & $\$ 130$ & 2000 & 1916 & $\$ 120,000$ \\
\hline 160 & 584 & $\$ 87$ & 2000 & 1924 & $\$ 51,000$ \\
\hline 161 & 1,363 & $\$ 108$ & 1999 & 2000 & $\$ 146,999$ \\
\hline 162 & 1,363 & $\$ 64$ & 1998 & 1998 & $\$ 87,636$ \\
\hline 163 & 932 & $\$ 128$ & 2000 & 1943 & $\$ 119,000$ \\
\hline 164 & 995 & $\$ 107$ & 2000 & 1955 & $\$ 106,950$ \\
\hline 165 & 858 & $\$ 104$ & 2000 & 1971 & $\$ 89,000$ \\
\hline 166 & 858 & $\$ 128$ & 2000 & 1970 & $\$ 110,000$ \\
\hline 167 & 1,295 & $\$ 64$ & 2000 & 1922 & $\$ 83,000$ \\
\hline 168 & 1,200 & $\$ 44$ & 2000 & 2000 & $\$ 53,000$ \\
\hline 169 & 1,560 & $\$ 83$ & 2000 & 2000 & $\$ 129,000$ \\
\hline 171 & 1,128 & $\$ 74$ & 2000 & 1909 & $\$ 83,000$ \\
\hline 173 & 832 & $\$ 148$ & 2000 & 1926 & $\$ 122,865$ \\
\hline 174 & 851 & $\$ 140$ & 2000 & 1947 & $\$ 119,000$ \\
\hline 175 & 880 & $\$ 135$ & 2000 & 1950 & $\$ 119,000$ \\
\hline 176 & 1,038 & $\$ 120$ & 2000 & 1908 & $\$ 124,800$ \\
\hline 177 & 1,376 & $\$ 86$ & 2000 & 1925 & $\$ 118,500$ \\
\hline 178 & 1,212 & $\$ 91$ & 2000 & 1927 & $\$ 110,000$ \\
\hline 179 & 932 & $\$ 50$ & 2000 & 1922 & $\$ 47,000$ \\
\hline 180 & 2,418 & $\$ 50$ & 2000 & 1915 & $\$ 121,000$ \\
\hline 181 & 715 & $\$ 137$ & 2000 & 1925 & $\$ 98,000$ \\
\hline 182 & 716 & $\$ 133$ & 2000 & 1924 & $\$ 95,000$ \\
\hline 183 & 1,212 & $\$ 91$ & 2000 & 1927 & $\$ 110,000$ \\
\hline 184 & 960 & $\$ 105$ & 2000 & 1973 & $\$ 101,000$ \\
\hline 185 & 1,048 & $\$ 96$ & 2000 & 1925 & $\$ 101,000$ \\
\hline 186 & 572 & $\$ 97$ & 1999 & 1950 & $\$ 55,650$ \\
\hline 187 & 1,182 & $\$ 102$ & 2000 & 1951 & $\$ 120,500$ \\
\hline 188 & 936 & $\$ 120$ & 2000 & 1959 & $\$ 112,000$ \\
\hline 189 & 1,128 & $\$ 68$ & 2000 & 1981 & $\$ 76,388$ \\
\hline 190 & 544 & $\$ 149$ & 2000 & 1926 & $\$ 80,914$ \\
\hline 191 & 810 & $\$ 130$ & 2000 & 1927 & $\$ 105,000$ \\
\hline 193 & 1,370 & $\$ 92$ & 2000 & 2000 & $\$ 125,470$ \\
\hline 194 & 1,336 & $\$ 71$ & 2000 & 1941 & $\$ 94,700$ \\
\hline 195 & 1,214 & $\$ 84$ & 2000 & 1916 & $\$ 101,884$ \\
\hline & & & & \\
\hline
\end{tabular}




\begin{tabular}{|c|c|c|c|c|c|}
\hline ID & OWNER & PHYS_RATE & BLOCK_RATE & PROX_GROC & PROX_BUS \\
\hline 1 & NECDC & 1.6 & 2 & 0.75 & 0.13 \\
\hline 2 & NECDC & 1.6 & 3 & 0.56 & 0.19 \\
\hline 4 & NECDC & 1.6 & 2 & 0.75 & 0.13 \\
\hline 5 & NECDC & 1.3 & 2 & 0.56 & 0.13 \\
\hline 6 & NECDC & 1.7 & 3 & 0.63 & 0.06 \\
\hline 7 & NECDC & 2.1 & 4 & 0.81 & 0.06 \\
\hline 8 & NECDC & 1.3 & 2 & 0.88 & 0.06 \\
\hline 8 & NECDC & 2.4 & 3 & 0.56 & 0.13 \\
\hline 9 & NECDC & 1.4 & $\sqrt{2}$ & 0.75 & 0.13 \\
\hline 10 & NECDC & 1.7 & 3 & 0.56 & 0.13 \\
\hline 11 & NECDC & 1.6 & 3 & 0.56 & 0.06 \\
\hline 12 & NECDC & 1.6 & 2 & 0.25 & 0.06 \\
\hline 13 & NECDC & 2 & 3 & 0.75 & 0.13 \\
\hline 14 & NECDC & 1.6 & 2 & 0.69 & 0.13 \\
\hline 15 & NECDC & 1.4 & 3 & 0.75 & 0.13 \\
\hline 16 & NECDC & 1.6 & 3 & 0.69 & 0.19 \\
\hline 16 & Market-Rate & 1.6 & 3 & 0.69 & 0.19 \\
\hline 17 & NECDC & 1.6 & 2 & 0.69 & 0.13 \\
\hline 18 & NECDC & 1.7 & 2 & 0.69 & 0.13 \\
\hline 18 & NECDC & 1.6 & 2 & 0.31 & 0.19 \\
\hline 19 & NECDC & 1.6 & 2 & 0.69 & 0.13 \\
\hline 20 & NECDC & 1.7 & 2 & 0.69 & 0.13 \\
\hline 20 & NECDC & 1.7 & 2 & 0.44 & 0.25 \\
\hline 20 & NECDC & 1.6 & 3 & 0.44 & 0.19 \\
\hline 21 & NECDC & 1.1 & 2 & 0.44 & 0.25 \\
\hline 22 & NECDC & 1.3 & 3 & 0.44 & 0.25 \\
\hline 22 & NECDC & 1.7 & 3 & 0.50 & 0.25 \\
\hline 2 & NECDC & 1.1 & 3 & 0.25 & 0.25 \\
\hline 24 & NECDC & 1.4 & 3 & 0.44 & 0.19 \\
\hline 25 & NECDC & 2.3 & 2 & 0.56 & 0.13 \\
\hline 26 & NECDC & 1.7 & 3 & 0.63 & 0.06 \\
\hline 27 & NECDC & 1.4 & 3 & 0.63 & 0.13 \\
\hline 28 & NECDC & 1.6 & 2 & 0.44 & 0.06 \\
\hline 29 & NECDC & 1.3 & 2 & 0.75 & 0.13 \\
\hline 30 & NECDC & 1.1 & 2 & 0.75 & 0.13 \\
\hline 31 & NECDC & 1.3 & 3 & 0.19 & 0.13 \\
\hline 32 & NECDC & 1 & 3 & 0.50 & 0.06 \\
\hline 33 & NECDC & 1.4 & 2 & 0.75 & 0.13 \\
\hline 34 & NECDC & 1.4 & 2 & 0.75 & 0.13 \\
\hline 35 & NECDC & 1.3 & 2 & 0.75 & 0.13 \\
\hline 36 & NECDC & 1.6 & 2 & 0.25 & 0.31 \\
\hline 37 & NECDC & 1.6 & 2 & 0.25 & 0.31 \\
\hline 38 & NECDC & 1.3 & 3 & 0.44 & 0.19 \\
\hline 39 & NECDC & 1.6 & 2 & 0.94 & 0.06 \\
\hline 40 & NECDC & 1.6 & 3 & 0.38 & 0.06 \\
\hline 41 & NECDC & 1.3 & 3 & 0.38 & 0.06 \\
\hline 42 & NECDC & 1.6 & 3 & 0.44 & 0.06 \\
\hline 43 & NECDC & 1.6 & 3 & 0.44 & 0.06 \\
\hline 44 & NECDC & 1.1 & 3 & 0.50 & 0.13 \\
\hline 45 & NECDC & 1.1 & 1 & 0.38 & 0.25 \\
\hline
\end{tabular}




\begin{tabular}{|c|c|c|c|c|c|}
\hline ID & OWNER & PHYS_RATE & BLOCK_RATE & PROX_GROC & PROX_BUS \\
\hline 46 & NECDC & 1.1 & 3 & 0.25 & 0.25 \\
\hline 47 & NECDC & 1.7 & 2 & 0.75 & 0.13 \\
\hline 48 & NECDC & 1.4 & 3 & 0.44 & 0.19 \\
\hline 49 & NECDC & 1.3 & 3 & 0.56 & 0.19 \\
\hline 50 & NECDC & 1.6 & 3 & 0.38 & 0.06 \\
\hline 51 & NECDC & 1.1 & 3 & 0.56 & 0.06 \\
\hline 52 & NECDC & 1.6 & 3 & 0.63 & 0.06 \\
\hline 53 & NECDC & 1.3 & 3 & 0.44 & 0.25 \\
\hline 54 & NECDC & 1.4 & 3 & 0.44 & 0.06 \\
\hline 55 & Market-Rate & 1.9 & 3 & 0.56 & 0.13 \\
\hline 56 & Market-Rate & 1.9 & 2 & 0.75 & 0.13 \\
\hline 57 & Market-Rate & 1.7 & 3 & 0.69 & 0.06 \\
\hline 58 & Market-Rate & 1.1 & 2 & 0.25 & 0.25 \\
\hline 59 & Market-Rate & 1.1 & 2 & 0.69 & 0.06 \\
\hline 60 & Market-Rate & 1 & 4 & 0.88 & 0.06 \\
\hline 61 & Market-Rate & 1.4 & 3 & 0.75 & 0.13 \\
\hline 62 & Market-Rate & 1.4 & 2 & 0.56 & 0.06 \\
\hline 63 & Market-Rate & 1.3 & 2 & 0.31 & 0.13 \\
\hline 64 & Market-Rate & 1.9 & 3 & 0.50 & 0.06 \\
\hline 65 & Market-Rate & 1.4 & 2 & 0.81 & 0.13 \\
\hline 66 & Market-Rate & 1.4 & 2 & 0.75 & 0.13 \\
\hline 67 & Market-Rate & 1.6 & 3 & 0.81 & 0.06 \\
\hline 68 & Market-Rate & 1 & 2 & 1.50 & 0.06 \\
\hline 69 & Market-Rate & 1.4 & 3 & 0.38 & 0.13 \\
\hline 70 & Market-Rate & 1.3 & 2 & 0.25 & 0.06 \\
\hline 71 & Market-Rate & 1.7 & 2 & 1.25 & 0.19 \\
\hline 73 & Market-Rate & 1.6 & 3 & 0.44 & 0.13 \\
\hline 74 & Market-Rate & 2 & 3 & 0.13 & 0.06 \\
\hline 75 & Market-Rate & 1.4 & 3 & 0.69 & 0.25 \\
\hline 77 & Market-Rate & 1.6 & 3 & 0.63 & 0.19 \\
\hline 78 & Market-Rate & 1.1 & 3 & 0.56 & 0.13 \\
\hline 79 & Market-Rate & 1.4 & 2 & 0.56 & 0.13 \\
\hline 80 & Market-Rate & 2 & 3 & 1.25 & 0.13 \\
\hline 81 & Market-Rate & 1.5 & 3 & 1.50 & 0.13 \\
\hline 82 & Market-Rate & 1.1 & 4 & 0.25 & 0.19 \\
\hline 83 & Market-Rate & 2 & 3 & 0.69 & 0.19 \\
\hline 84 & Market-Rate & 2 & 4 & 0.31 & 0.19 \\
\hline 85 & Market-Rate & 1.9 & 3 & 0.56 & 0.19 \\
\hline 86 & Market-Rate & 1 & 3 & 0.56 & 0.13 \\
\hline 87 & Market-Rate & 1.6 & 3 & 1.00 & 0.25 \\
\hline 88 & Market-Rate & 1 & 3 & 0.56 & 0.13 \\
\hline 89 & Market-Rate & 1.1 & 3 & 0.44 & 0.19 \\
\hline 90 & Market-Rate & 1.4 & 3 & 0.19 & 0.06 \\
\hline 91 & Market-Rate & 1 & 2 & 0.69 & 0.13 \\
\hline 92 & Market-Rate & 1.9 & 2 & 1.50 & 0.06 \\
\hline 93 & Market-Rate & 1.3 & 3 & 0.19 & 0.06 \\
\hline 94 & Market-Rate & 2 & 3 & 0.31 & 0.19 \\
\hline 95 & Market-Rate & 1.3 & 3 & 0.75 & 0.25 \\
\hline 96 & Market-Rate & 2 & 3 & 0.63 & 0.25 \\
\hline 97 & Market-Rate & 1.4 & 3 & 0.75 & 0.06 \\
\hline
\end{tabular}




\begin{tabular}{|c|c|c|c|c|c|}
\hline ID & OWNER & PHYS RATE & BLOCK_RATE & PROX_GROC & PROX_BUS \\
\hline 98 & NECDC & 1 & 3 & 0.63 & 0.13 \\
\hline 99 & NECDC & 1.1 & 3 & 0.44 & 0.13 \\
\hline 100 & Market-Rate & 1.6 & 2 & 0.13 & 0.13 \\
\hline 102 & HOST & 1 & 2 & 0.56 & 0.13 \\
\hline 103 & Market-Rate & 1.3 & 2 & 0.63 & 0.13 \\
\hline 104 & Market-Rate & 1.3 & 3 & 0.56 & 0.06 \\
\hline 106 & Market-Rate & 1.7 & 3 & 0.56 & 0.06 \\
\hline 107 & Market-Rate & 1.1 & 2 & 0.50 & 0.06 \\
\hline 108 & NECDC & 1.1 & 3 & 0.50 & 0.13 \\
\hline 109 & NECDC & 1.3 & 3 & 0.44 & 0.19 \\
\hline 110 & NECDC & 1.1 & 3 & 0.44 & 0.19 \\
\hline 111 & NECDC & 1.1 & 3 & 0.44 & 0.19 \\
\hline 112 & Habitat for Humanity & 1.3 & 4 & 0.50 & 0.13 \\
\hline 113 & Habitat for Humanity & 1.1 & 4 & 0.44 & 0.13 \\
\hline 114 & Habitat for Humanity & 1.1 & 4 & 0.44 & 0.13 \\
\hline 115 & Habitat for Humanity & 1.3 & 4 & 0.44 & 0.13 \\
\hline 116 & Habitat for Humanity & 1 & 3 & 0.19 & 0.19 \\
\hline 117 & Habitat for Humanity & 1 & 3 & 0.19 & 0.19 \\
\hline 118 & Habitat for Humanity & 1 & 3 & 0.19 & 0.19 \\
\hline 119 & Market-Rate & 1.3 & 3 & 0.13 & 0.19 \\
\hline 120 & Market-Rate & 1.6 & 3 & 0.38 & 0.19 \\
\hline 121 & Market-Rate & 1.4 & 3 & 0.44 & 0.19 \\
\hline 122 & HOST & 1 & 1 & 0.94 & 0.19 \\
\hline 123 & Market-Rate & 1.3 & 3 & 1.00 & 0.06 \\
\hline 125 & Market-Rate & 1.4 & 2 & 0.50 & 0.06 \\
\hline 126 & Market-Rate & 1.7 & 2 & 0.44 & 0.13 \\
\hline 127 & Market-Rate & 1.4 & 2 & 0.44 & 0.13 \\
\hline 128 & Market-Rate & 1 & 1 & 1.25 & 0.13 \\
\hline 129 & Market-Rate & 1 & 3 & 0.19 & 0.13 \\
\hline 130 & Habitat for Humanity & 1 & 2 & 0.31 & 0.13 \\
\hline 131 & Market-Rate & 1.1 & 3 & 0.44 & 0.06 \\
\hline 132 & Habitat for Humanity & 1.3 & 3 & 0.56 & 0.13 \\
\hline 133 & Market-Rate & 1 & 3 & 0.69 & 0.25 \\
\hline 134 & Market-Rate & 1.3 & 3 & 0.69 & 0.25 \\
\hline 135 & \begin{tabular}{|l|} 
Market-Rate \\
\end{tabular} & 1.3 & 2 & 0.63 & 0.13 \\
\hline 136 & NECDC & 1 & 3 & 0.63 & 0.13 \\
\hline 137 & NECDC & 1 & 3 & 0.75 & 0.13 \\
\hline 138 & Habitat for Humanity & 1 & 3 & 0.63 & 0.06 \\
\hline 139 & Habitat for Humanity & 1 & 3 & 0.63 & 0.06 \\
\hline 140 & Market-Rate & 1.4 & 4 & 0.81 & 0.06 \\
\hline 141 & Market-Rate & 1.7 & 4 & 0.81 & 0.06 \\
\hline 142 & Market-Rate & 1.4 & 2 & 0.81 & 0.06 \\
\hline 143 & Market-Rate & 1 & 2 & 0.75 & 0.06 \\
\hline 144 & NECDC & 1 & 2 & 0.69 & 0.19 \\
\hline 145 & NECDC & 1.3 & 2 & 0.69 & 0.19 \\
\hline 146 & NECDC & 1 & 2 & 0.88 & 0.13 \\
\hline 147 & HOST & 1 & 2 & 0.75 & 0.13 \\
\hline 148 & Market-Rate & 1.1 & 3 & 0.56 & 0.19 \\
\hline 149 & Market-Rate & 1.4 & 3 & 0.31 & 0.19 \\
\hline 150 & Market-Rate & 1.6 & 3 & 0.19 & 0.13 \\
\hline
\end{tabular}




\begin{tabular}{|c|c|c|c|c|c|}
\hline ID & OWNER & PHYS_RATE & BLOCK RATE & PROX_GROC & PROX_BUS \\
\hline 151 & Market-Rate & 1 & 2 & 0.19 & 0.06 \\
\hline 152 & Market-Rate & 1.3 & $\sqrt{3}$ & $\widehat{0.44}$ & 0.06 \\
\hline 153 & Market-Rate & 1.3 & 4 & 0.56 & 0.19 \\
\hline 154 & Market-Rate & 1 & 2 & 0.63 & 0.06 \\
\hline 155 & Market-Rate & 1.4 & 3 & 0.63 & 0.06 \\
\hline 156 & Market-Rate & 1.1 & 4 & 0.69 & 0.06 \\
\hline 157 & Market-Rate & 1 & 2 & 0.75 & 0.13 \\
\hline 159 & Market-Rate & 1.1 & 2 & 0.81 & 0.13 \\
\hline 160 & Market-Rate & 1 & 3 & 0.81 & 0.06 \\
\hline 161 & HOST & 1 & 2 & 0.88 & 0.13 \\
\hline 162 & HOST & 1 & 2 & 0.94 & 0.13 \\
\hline 163 & Market-Rate & 1.6 & 1 & 1.25 & 0.13 \\
\hline 164 & Market-Rate & 1 & 1 & 1.50 & 0.19 \\
\hline 165 & Market-Rate & 1.8 & 4 & 1.50 & 0.19 \\
\hline 166 & Market-Rate & 1.1 & 3 & 1.50 & 0.19 \\
\hline 167 & Market-Rate & 1.9 & 3 & 1.50 & 0.19 \\
\hline 168 & Habitat for Humanity & 1 & $\sqrt{2}$ & 1.00 & 0.06 \\
\hline 169 & NECDC & 1.1 & 2 & 0.69 & 0.19 \\
\hline 171 & Market-Rate & $\overline{1.1}$ & 3 & 0.63 & 0.13 \\
\hline 173 & Market-Rate & 1.3 & 2 & 0.63 & 0.19 \\
\hline 174 & Market-Rate & 1.3 & 1 & 0.63 & 0.13 \\
\hline 175 & Market-Rate & 1.4 & $\sqrt{1}$ & 0.38 & 0.13 \\
\hline 176 & Market-Rate & 1.3 & 1 & 0.44 & 0.13 \\
\hline 177 & Market-Rate & 1.4 & $\sqrt{2}$ & 0.38 & 0.06 \\
\hline 178 & Market-Rate & $\overline{1.1}$ & 2 & 0.44 & 0.19 \\
\hline 179 & Market-Rate & 1.3 & 4 & $\longdiv { 0 . 1 3 }$ & 0.13 \\
\hline 180 & Market-Rate & 1.4 & $\sqrt{3}$ & 0.19 & 0.06 \\
\hline 181 & Market-Rate & 1.3 & 2 & 0.38 & 0.19 \\
\hline 182 & Market-Rate & 1.3 & 3 & 0.31 & 0.25 \\
\hline 183 & Market-Rate & $\overline{1.4}$ & 3 & 0.13 & 0.13 \\
\hline 184 & Market-Rate & 1.3 & 4 & 0.38 & 0.19 \\
\hline 185 & Market-Rate & 1.1 & 3 & 0.56 & 0.06 \\
\hline 186 & Habitat for Humanity & 1.6 & 2 & 0.56 & 0.13 \\
\hline 187 & Market-Rate & 1 & 3 & 0.94 & 0.13 \\
\hline 188 & Market-Rate & 1.1 & 3 & 0.81 & 0.06 \\
\hline 189 & Market-Rate & 1.7 & 3 & 1.00 & 0.06 \\
\hline 190 & Market-Rate & 1.4 & 3 & 1.25 & 0.06 \\
\hline 191 & Market-Rate & 1.6 & 1 & 1.00 & 0.19 \\
\hline 193 & HOST & 1.1 & 1 & 0.88 & 0.13 \\
\hline 194 & Market-Rate & 1.9 & 2 & 1.00 & 0.25 \\
\hline 195 & Market-Rate & 1.3 & 3 & 0.38 & 0.13 \\
\hline
\end{tabular}




\begin{tabular}{|c|c|c|c|c|c|}
\hline ID & PROX_RETAIL & PROX PARKS & PROX_SCHL & PROX_CBD & CRIME \\
\hline 1 & 0.75 & 0.13 & 0.50 & 1.5 & $32-50$ \\
\hline 2 & 0.75 & 0.25 & 0.31 & 1.5 & $51-59$ \\
\hline 4 & 0.75 & 0.13 & 0.44 & 1.5 & $32-50$ \\
\hline 5 & 0.50 & 0.25 & 0.25 & 2 & $51-59$ \\
\hline 6 & 0.75 & 0.25 & 0.31 & 1.5 & $51-59$ \\
\hline 7 & 0.75 & 0.19 & 0.50 & 1.5 & $32-50$ \\
\hline 8 & 1.00 & 0.06 & 0.75 & 1.5 & $32-50$ \\
\hline 8 & 0.50 & 0.25 & 0.25 & 1.5 & $51-59$ \\
\hline 9 & 0.75 & 0.25 & 0.38 & 2 & $51-59$ \\
\hline 10 & 0.38 & 0.25 & 0.31 & 2 & $51-59$ \\
\hline 11 & 0.38 & 0.25 & 0.31 & 2 & $51-59$ \\
\hline 12 & 0.13 & 0.25 & 0.38 & 2.5 & $51-59$ \\
\hline 13 & 0.50 & 0.25 & 0.44 & 2 & $51-59$ \\
\hline 14 & 0.75 & 0.25 & 0.75 & 1.5 & $32-50$ \\
\hline 15 & 0.75 & 0.25 & 0.75 & 1.5 & $32-50$ \\
\hline 16 & 0.75 & 0.25 & 0.75 & 1.5 & $51-59$ \\
\hline 16 & 0.75 & 0.25 & 0.75 & 1.5 & $51-59$ \\
\hline 17 & 0.75 & 0.25 & 0.75 & 1.5 & $32-50$ \\
\hline 18 & 0.44 & 0.06 & 0.75 & 2 & $51-59$ \\
\hline 18 & 0.50 & 0.25 & 0.50 & 2.5 & $120-150$ \\
\hline 19 & 0.44 & 0.06 & 0.75 & 2 & $51-59$ \\
\hline 20 & 0.44 & 0.06 & 0.75 & 2 & $51-59$ \\
\hline 20 & 0.50 & 0.31 & 0.50 & 2.5 & $120-150$ \\
\hline 20 & 0.50 & 0.25 & 0.75 & 2 & $51-59$ \\
\hline 21 & 0.50 & 0.44 & 0.50 & 2.5 & $120-150$ \\
\hline 22 & 0.50 & 0.25 & 0.50 & 2 & $51-59$ \\
\hline 22 & 0.75 & 0.19 & 0.75 & 2 & $51-59$ \\
\hline 23 & 0.31 & 0.13 & 1.00 & 2.5 & $51-59$ \\
\hline 24 & 0.38 & 0.06 & 0.75 & 2.5 & $51-59$ \\
\hline 25 & 0.38 & 0.13 & 0.75 & 2 & $51-59$ \\
\hline 26 & 0.75 & 0.19 & 0.75 & 2.5 & $32-50$ \\
\hline 27 & 0.75 & 0.19 & 0.75 & 2.5 & $32-50$ \\
\hline 28 & 0.50 & 0.13 & 0.75 & 1.5 & $51-59$ \\
\hline 29 & 0.75 & 0.25 & 0.75 & 1.5 & $32-50$ \\
\hline 30 & 0.75 & 0.25 & 0.75 & 1.5 & $32-50$ \\
\hline 31 & 0.13 & 0.25 & 0.75 & 2.5 & $51-59$ \\
\hline 32 & 0.50 & 0.25 & 0.75 & 2 & $51-59$ \\
\hline 33 & 0.75 & 0.25 & 0.75 & 1.5 & $32-50$ \\
\hline 34 & 0.75 & 0.25 & 0.75 & 1.5 & $32-50$ \\
\hline 35 & 0.75 & 0.13 & 0.44 & 1.5 & $32-50$ \\
\hline 36 & 0.25 & 0.19 & 1.00 & 2.5 & $51-59$ \\
\hline 37 & 0.25 & 0.19 & 1.00 & 2.5 & $51-59$ \\
\hline 38 & 0.38 & 0.13 & 0.75 & 2.5 & $51-59$ \\
\hline 39 & 1.00 & 0.19 & 0.75 & 1.5 & $32-50$ \\
\hline \begin{tabular}{|l|}
40 \\
\end{tabular} & 0.13 & 0.25 & 0.50 & 2 & $51-59$ \\
\hline 4 & 0.13 & 0.19 & 0.75 & 2.5 & $51-59$ \\
\hline 42 & 0.31 & 0.19 & 0.75 & 2.5 & $51-59$ \\
\hline 43 & 0.31 & 0.19 & 0.75 & 2.5 & $51-59$ \\
\hline 44 & 0.44 & 0.06 & 0.75 & 2.5 & $51-59$ \\
\hline 45 & 0.44 & 0.13 & 0.44 & 1.5 & $27-31$ \\
\hline
\end{tabular}




\begin{tabular}{|l|l|l|l|l|l|}
\hline ID & PROX_RETAIL & PROX_PARKS & PROX_SCHL & PROX_CBD & CRIME \\
\hline 46 & 0.31 & 0.25 & 0.38 & 2 & $51-59$ \\
\hline 47 & 0.75 & 0.25 & 0.75 & 1.5 & $32-50$ \\
\hline 48 & 0.50 & 0.25 & 0.38 & 2 & $51-59$ \\
\hline 49 & 0.50 & 0.25 & 0.25 & 1.5 & $51-59$ \\
\hline 50 & 0.13 & 0.19 & 0.75 & 2.5 & $51-59$ \\
\hline 51 & 0.50 & 0.13 & 0.75 & 2.5 & $51-59$ \\
\hline 52 & 0.50 & 0.25 & 0.25 & 2 & $51-59$ \\
\hline 53 & 0.50 & 0.25 & 0.38 & 2 & $51-59$ \\
\hline 54 & 0.25 & 0.19 & 0.75 & 2.5 & $51-59$ \\
\hline 55 & 1.00 & 0.13 & 1.25 & 3 & $27-31$ \\
\hline 56 & 0.44 & 0.25 & 0.25 & 3.5 & $51-59$ \\
\hline 57 & 0.50 & 0.06 & 0.75 & 3 & $32-50$ \\
\hline 58 & 0.44 & 0.06 & 1.00 & 3 & $27-31$ \\
\hline 59 & 1.00 & 0.25 & 1.00 & 4 & $27-31$ \\
\hline 60 & 1.00 & 0.19 & 0.75 & 2.5 & $32-50$ \\
\hline 61 & 0.44 & 0.25 & 0.25 & 3.5 & $51-59$ \\
\hline 62 & 0.75 & 0.19 & 1.00 & 3 & $27-31$ \\
\hline 63 & 0.75 & 0.19 & 0.44 & 3 & $27-31$ \\
\hline 64 & 0.38 & 0.19 & 0.75 & 2.5 & $51-59$ \\
\hline 65 & 1.00 & 0.25 & 0.75 & 3 & $23-26$ \\
\hline 66 & 0.31 & 0.06 & 0.44 & 3.5 & $51-59$ \\
\hline 67 & 0.50 & 0.25 & 0.25 & 3 & $51-59$ \\
\hline 68 & 1.00 & 0.13 & 0.31 & 4 & $51-59$ \\
\hline 69 & 0.19 & 0.25 & 0.31 & 3 & $32-50$ \\
\hline 70 & 0.75 & 0.19 & 0.38 & 3 & $27-31$ \\
\hline 71 & 1.00 & 0.19 & 0.19 & 3.5 & $51-59$ \\
\hline 73 & 0.50 & 0.25 & 0.75 & 2 & $51-59$ \\
\hline 74 & 0.25 & 0.25 & 0.19 & 3 & $32-50$ \\
\hline 75 & 1.00 & 0.06 & 1.00 & 3.5 & $27-31$ \\
\hline 77 & 1.00 & 0.06 & 1.00 & 3 & $27-31$ \\
\hline 78 & 0.31 & 0.06 & 0.50 & 3 & $32-50$ \\
\hline 79 & 0.19 & 0.13 & 0.44 & 3.5 & $51-59$ \\
\hline 80 & 0.75 & 0.13 & 0.31 & 3.5 & $51-59$ \\
\hline 81 & 1.00 & 0.13 & 0.38 & 4 & $51-59$ \\
\hline 82 & 0.50 & 0.25 & 0.38 & 3 & $27-31$ \\
\hline 83 & 1.00 & 0.06 & 1.00 & 3.5 & $27-31$ \\
\hline 84 & 0.38 & 0.25 & 0.25 & 3.5 & $51-59$ \\
\hline 85 & 0.38 & 0.06 & 0.50 & 3 & $32-50$ \\
\hline 86 & 0.75 & 0.19 & 0.75 & 2 & $51-59$ \\
\hline 87 & 0.75 & 0.25 & 0.44 & 4 & $51-59$ \\
\hline 88 & 0.75 & 0.06 & 1.25 & 3 & $27-31$ \\
\hline 89 & 0.75 & 0.13 & 1.00 & 3 & $27-31$ \\
\hline 90 & 0.75 & 0.25 & 0.38 & 3 & $27-31$ \\
\hline 91 & 0.75 & 0.25 & 0.75 & 2 & $51-59$ \\
\hline 92 & 1.75 & 0.25 & 0.13 & 4 & $23-26$ \\
\hline 93 & 0.31 & 0.25 & 0.31 & 3 & $32-50$ \\
\hline 94 & 0.75 & 0.19 & 0.38 & 3 & $27-31$ \\
\hline 95 & 1.00 & 0.13 & 1.00 & 3.5 & $27-31$ \\
\hline 96 & 1.00 & 0.13 & 1.25 & 3 & $27-31$ \\
\hline 97 & 0.44 & 0.13 & 0.38 & 3 & $32-50$ \\
\hline & & & & \\
\hline
\end{tabular}




\begin{tabular}{|c|c|c|c|c|c|}
\hline ID & PROX_RETAIL & PROX_PARKS & PROX_SCHL & PROX_CBD & CRIME \\
\hline 98 & 0.75 & 0.25 & 0.75 & 1.5 & $51-59$ \\
\hline 99 & 0.50 & 0.25 & 0.75 & 2 & $51-59$ \\
\hline 100 & 0.19 & 0.13 & 0.31 & 2 & $23-26$ \\
\hline 102 & 0.75 & 0.13 & 0.38 & 2.5 & $23-26$ \\
\hline 103 & 0.75 & 0.19 & 0.44 & 2.5 & $32-50$ \\
\hline 104 & 0.50 & 0.13 & 0.75 & 2.5 & $51-59$ \\
\hline 106 & 0.75 & 0.19 & 0.75 & 2.5 & $32-50$ \\
\hline 107 & 0.75 & 0.25 & 1.00 & 2.5 & $32-50$ \\
\hline 108 & 0.44 & 0.06 & 0.75 & 2.5 & $32-50$ \\
\hline 109 & 0.38 & 0.06 & 0.75 & \begin{tabular}{|l|}
2.5 \\
\end{tabular} & $51-59$ \\
\hline 110 & 0.38 & 0.13 & 0.75 & 2.5 & $51-59$ \\
\hline 111 & 0.38 & 0.06 & 0.75 & 2.5 & $51-59$ \\
\hline 112 & 0.44 & 0.13 & 1.00 & 2.5 & $32-50$ \\
\hline 113 & 0.44 & 0.13 & 1.00 & 2.5 & $32-50$ \\
\hline 114 & 0.44 & 0.13 & 1.00 & 2.5 & $32-50$ \\
\hline 115 & 0.44 & 0.13 & 1.00 & 2.5 & $32-50$ \\
\hline 116 & 0.13 & 0.25 & 0.75 & 2.5 & $51-59$ \\
\hline 117 & 0.13 & 0.25 & 0.75 & 2.5 & $51-59$ \\
\hline 118 & \begin{tabular}{|l|}
0.13 \\
\end{tabular} & 0.25 & 0.75 & 2.5 & $51-59$ \\
\hline 119 & 0.19 & 0.13 & 0.75 & 2.5 & $51-59$ \\
\hline 120 & 0.31 & 0.19 & 1.00 & 2.5 & $51-59$ \\
\hline 121 & 0.38 & 0.06 & 0.75 & 2.5 & $51-59$ \\
\hline 122 & 1.00 & 0.13 & 0.75 & 3 & $23-26$ \\
\hline 123 & 1.00 & 0.25 & 0.75 & 3 & $23-26$ \\
\hline 125 & 0.75 & 0.06 & 1.00 & 3 & $27-31$ \\
\hline 126 & 0.50 & 0.06 & 1.00 & 3 & $27-31$ \\
\hline 127 & 0.50 & 0.13 & 1.00 & 2.5 & $32-50$ \\
\hline 128 & 1.50 & 0.13 & 0.44 & 3 & $23-26$ \\
\hline 129 & 0.44 & 0.19 & 0.75 & 3 & $27-31$ \\
\hline 130 & 0.75 & 0.19 & 1.00 & 3 & $27-31$ \\
\hline 131 & 0.75 & 0.19 & 1.00 & 3 & $27-31$ \\
\hline 132 & 0.75 & 0.25 & 1.00 & 3 & $27-31$ \\
\hline 133 & 1.00 & 0.13 & 1.25 & 3.5 & $27-31$ \\
\hline 134 & 1.00 & 0.13 & 1.25 & 3 & $27-31$ \\
\hline 135 & 1.00 & 0.25 & 1.25 & 3 & $27-31$ \\
\hline 136 & 0.75 & 0.25 & 0.75 & 1.5 & $51-59$ \\
\hline 137 & 0.50 & 0.19 & 0.50 & 2 & $51-59$ \\
\hline 138 & 0.38 & 0.25 & 0.31 & 2 & $51-59$ \\
\hline 139 & 0.38 & 0.25 & 0.31 & 2 & $51-59$ \\
\hline 140 & 1.00 & 0.13 & 0.75 & 1.5 & $32-50$ \\
\hline 141 & 0.75 & 0.19 & 0.50 & 1.5 & $32-50$ \\
\hline 142 & 0.75 & 0.06 & 0.50 & 1.5 & $32-50$ \\
\hline 143 & 0.75 & 0.13 & 0.44 & 1.5 & $32-50$ \\
\hline 144 & 0.75 & 0.13 & 0.44 & 1.5 & $32-50$ \\
\hline 145 & 0.75 & 0.13 & 0.44 & 1.5 & $32-50$ \\
\hline 146 & 1.00 & 0.06 & 0.75 & 1.5 & $32-50$ \\
\hline 147 & 0.75 & 0.13 & 0.50 & 1.5 & $32-50$ \\
\hline 148 & 0.50 & 0.25 & 0.25 & 1.5 & $51-59$ \\
\hline 149 & 0.25 & 0.25 & 0.06 & 2 & $51-59$ \\
\hline 150 & 0.19 & 0.13 & 0.25 & 2.5 & $51-59$ \\
\hline
\end{tabular}




\begin{tabular}{|l|l|l|l|l|l|}
\hline ID & PROX_RETAIL & PROX_PARKS & PROX_SCHL & PROX_CBD & CRIME \\
\hline 151 & 0.19 & 0.06 & 0.25 & 2.5 & $51-59$ \\
\hline 152 & 0.75 & 0.06 & 0.44 & 2.5 & $27-31$ \\
\hline 153 & 0.44 & 0.06 & 0.75 & 2.5 & $32-50$ \\
\hline 154 & 0.75 & 0.06 & 0.44 & 2.5 & $32-50$ \\
\hline 155 & 0.44 & 0.06 & 0.75 & 3 & $32-50$ \\
\hline 156 & 0.44 & 0.06 & 0.44 & 3 & $32-50$ \\
\hline 157 & 0.75 & 0.13 & 0.75 & 3 & $32-50$ \\
\hline 159 & 0.75 & 0.19 & 0.50 & 3 & $32-50$ \\
\hline 160 & 0.50 & 0.25 & 0.25 & 3 & $51-59$ \\
\hline 161 & 0.75 & 0.25 & 0.19 & 3.5 & $51-59$ \\
\hline 162 & 0.75 & 0.25 & 0.13 & 3.5 & $51-59$ \\
\hline 163 & 0.75 & 0.25 & 0.19 & 3.5 & $51-59$ \\
\hline 164 & 1.00 & 0.13 & 0.25 & 3.5 & $51-59$ \\
\hline 165 & 1.00 & 0.06 & 0.50 & 4 & $51-59$ \\
\hline 166 & 1.00 & 0.06 & 0.38 & 4 & $51-59$ \\
\hline 167 & 1.00 & 0.13 & 0.75 & 4 & $51-59$ \\
\hline 168 & 1.00 & 0.25 & 0.75 & 1 & $32-50$ \\
\hline 169 & 0.75 & 0.13 & 0.44 & 1.5 & $32-50$ \\
\hline 171 & 0.75 & 0.13 & 0.19 & 1.5 & $51-59$ \\
\hline 173 & 0.75 & 0.19 & 0.19 & 2 & $51-59$ \\
\hline 174 & 0.75 & 0.19 & 0.25 & 2 & $51-59$ \\
\hline 175 & 0.44 & 0.13 & 0.25 & 2 & $51-59$ \\
\hline 176 & 0.50 & 0.19 & 0.25 & 2 & $51-59$ \\
\hline 177 & 0.44 & 0.19 & 0.25 & 2 & $51-59$ \\
\hline 178 & 0.75 & 0.25 & 0.25 & 2 & $51-59$ \\
\hline 179 & 0.25 & 0.25 & 0.19 & 2 & $51-59$ \\
\hline 180 & 0.50 & 0.25 & 0.31 & 3 & $27-31$ \\
\hline 181 & 0.75 & 0.13 & 0.44 & 3 & $27-31$ \\
\hline 182 & 0.50 & 0.25 & 0.31 & 3.5 & $27-31$ \\
\hline 183 & 0.31 & 0.25 & 0.13 & 3 & $51-59$ \\
\hline 184 & 0.38 & 0.25 & 0.38 & 3.5 & $51-59$ \\
\hline 185 & 0.06 & 0.06 & 0.44 & 3.5 & $51-59$ \\
\hline 186 & 0.19 & 0.06 & 0.50 & 3.5 & $51-59$ \\
\hline 187 & 0.50 & 0.25 & 0.31 & 3.5 & $51-59$ \\
\hline 188 & 0.44 & 0.19 & 0.25 & 3.5 & $51-59$ \\
\hline 189 & 0.75 & 0.25 & 0.13 & 3.5 & $51-59$ \\
\hline 190 & 0.75 & 0.25 & 0.13 & 3.5 & $51-59$ \\
\hline 191 & 0.75 & 0.19 & 0.44 & 3 & $32-50$ \\
\hline 193 & 0.75 & 0.25 & 0.25 & 3 & $51-59$ \\
\hline 194 & 0.75 & 0.25 & 0.13 & 3.5 & $51-59$ \\
\hline 195 & 0.13 & 0.25 & 0.31 & 3 & $51-59$ \\
\hline & & & & 3 & \\
\hline
\end{tabular}

